\author{
UNIVERSIDADE DE SÃO PAULO \\ FACULDADE DE ODONTOLOGIA DE BAURU
}

ADRIANA SILVEIRA DE LIMA ELEUTÉRIO

Avaliação clínica da saúde bucal de pré-escolares do município de Alfenas e Areado - MG 

ADRIANA SILVEIRA DE LIMA ELEUTÉRIO

\section{Avaliação clínica da saúde bucal de pré-escolares do município de Alfenas e Areado - MG}

Tese apresentada à Faculdade de Odontologia de Bauru da Universidade de São Paulo para obtenção do título de mestre em Odontologia.

Área de Concentração: Odontopediatria

Orientadora: Profa. Dra. Salete Moura Bonifácio da Silva 


\begin{tabular}{|c|}
\hline Eleutério, Adriana Silveira de Lima \\
Avaliação clínica da saúde bucal de pré- \\
escolares do munićpio de Alfenas e Areado - MG / \\
Adriana Silveira de Lima Eleutério, 2010. \\
150p.: $30 \mathrm{~cm}$. \\
Dissertação (Mestrado) - Faculdade de \\
Odontologia de Bauru. Universidade de São Paulo. \\
Orientadora: Profa. Dra. Salete Moura \\
Bonifácio da Silva
\end{tabular}

Autorizo, exclusivamente para fins acadêmicos e científicos, a reprodução total ou parcial desta dissertação/tese, por processos fotocopiadores e outros meios eletrônicos.

Assinatura:

Data:

Comitê de Ética da FOB-USP

Protocolo ํo: 010//2008

Data: $08 / 05 / 2008$ 


DADOS CURRICULARES

\section{Adriana Silveira de Lima Eleutério}

07 de março de 1972

Filiação

1991-1994

$1999-2000$

2007-2009
Nascimento

São Paulo-SP

Vicente Cassiano de Lima

Maria da Glória Silveira de Lima

Curso de graduação em Odontologia pela Faculdade de Odontologia de Três Corações - MG - INCOR

Especialização em Odontopediatria pela Universidade Federal de Alfenas - MG UNIFAL

Curso de Pós-graduação em Odontopediatria, em nível de Mestrado, na Faculdade de Odontologia de Bauru, Universidade de São Paulo - SP 

“...Existem momentos que nunca serão apagados, pessoas que nunca serão esquecidas, pois a vida não vale um momento, mas há momentos que valem uma vida..."

(autor desconhecido) 



\section{DEDICATÓRIA}

À minha mãe, Maria da Glória.

Pela minha educação, pelos meus princípios e valores, por renunciar seus sonhos em prol dos meus, por sempre acolher minhas filhas, pelo seu amor infinito, pelos seus ensinamentos e sabedoria.

Ao meu esposo, Arilson.

Pelo companheirismo, cumplicidade, respeito, atenção, amor e carinho. Pelo incentivo e compreensão nas horas difíceis, por ser pai e mãe ao mesmo tempo, e principalmente, por sempre caminhar ao meu lado. Agradeço a Deus pelo grande amor que nos une. Afinal, de que valeria tanto esforço se não tivesse você para compartilhar esta grande alegria?

Às minhas filhas, Gabryela e Izabella.

À minha razão de vida. Obrigada por vocês existirem. Perdoem-me pela minha ausência. Um dia compreenderão o porquê de tudo isso. Obrigada por compartilharem comigo essa grande alegria e essa grande vitória.

São a vocês, Mãe, Arilson, Gabryela e Izabella, que dedico este tão precioso trabalho! 



\section{AGRADECIMENTOS ESPECIAIS}

\section{A Deus,}

Pelo dom da vida, pelo seu amor incondicional, pelas oportunidades concebidas, por renovar a cada dia minhas forças e por sempre me conceder vitórias em tudo que precisei. Agradeço a ti, Senhor, por tudo!

“...Tudo é do Pai toda honra e toda glória é d'Ele a vitória alcançada em minha vida..." 

Ao meu Pai Vicente (in memorian), agradeço, por ser prova de sua agradável e inesquecível existência, sinto-Ihe vivo dentro do meu coração. Você, hoje, é meu convidado especial.

Ao meu tio Aguinaldo e família, pelo amor e generosidade, à Thieme, pela atenção, ao meu tio Olinto e tia Rosa, pela preocupação dispensada a mim, às minhas cunhadas Rosângela e Daisy Mara, pela compreensão, apoio, e dedicação que tiveram com a minha família e, principalmente, com as minhas filhas.

À minha orientadora, Profa. Dra. Salete Moura Bonifácio da Silva, obrigada pela oportunidade de conhecê-la, por tê-la não só como orientadora, mas também como mestre, como exemplo de dedicação e competência. Agradeço-a sinceramente pela atenção, pela paciência, pelos conhecimentos transmitidos e pela confiança depositada em mim. Levarei sempre comigo seus conhecimentos e ensinamentos. Obrigada pela minha formação pessoal e profissional.

"Ser mestre é mais do que se dar ao trabalho de passar conhecimentos: é buscar no íntimo de cada aluno a vontade e a possibilidade de crescimento. É trazer de dentro para fora as qualidades e dons humanos. É saber que o sucesso também acontece no silêncio..." 

À Faculdade de Odontologia de Bauru, por meio de seu diretor Prof. Dr. Luiz Fernando Pegoraro.

À Comissão de Pós-Graduação da Faculdade de Odontologia de Bauru, por meio de sua presidente Profa. Dra. Maria Aparecida de Andrade Moreira Machado.

Aos professores da Disciplina de Odontopediatria da Faculdade de Odontologia de Bauru, Universidade de São Paulo, Dr. José Eduardo de Oliveira Lima, Dra. Maria Aparecida de Andrade Moreira Machado, Dr. Ruy César Camargo Abdo, Dra. Salete Moura Bonifácio da Silva, Dra. Daniela Rios e Dra. Thaís Marchini de Oliveira, obrigada a todos vocês pela acolhida nesta casa. Obrigada pelos ensinamentos, paciência e dedicação. Com vocês, subi o degrau do conhecimento e da sabedoria.

Às funcionárias da Disciplina de Odontopediatria da Faculdade de Odontologia de Bauru, Universidade de São Paulo, Fátima, Lílian, Estela, D. Lia, Tia Maria, e ainda Márcia, pela amizade, dedicação, carinho, colaboração e disposição em ajudar em todos os momentos.

Aos colegas do curso de Pós-Graduação,Thiago, Andréa, Júnia, Marco, Tatiana, Carla e Natalino, pela atenção.

Em especial, à Júnia, pelos momentos agradáveis, pela atenção, amizade e companheirismo.

Ao Prof. Dr. José Roberto Pereira Lauris, pela atenção, disponibilidade, tranqüilidade e competência nas análises estatísticas.

À Meg, Letícia e Leila, do Setor de Pós-Gradduação, pela atenção e carinho, durante o curso de Mestrado. 

Às funcionárias do Serviço de Biblioteca, em especial à Jane, Maristela, Rita, Cybelle, Mônica e Ademir, por toda atenção e educação.

Aos funcionários do Xerox da Biblioteca, Salvador e Adriana, pela gentileza no atendimento.

Aos professores e ex-professores da Disciplina de Odontopediatria da Unifal, Universidade Federal de Alfenas, Profa. Ana Beatriz Silveira Moretti, Profa. Dra. Daniela Silva Barroso de Oliveira, Prof. Dr. Edmêr Silvestre Pereira Júnior, Prof. Dr. Heitor Marques Honório; Prof. Dr. Maciro Manoel Pereira e Profa. Dra. Olinda Maria Barroso, pela amizade, atenção, carinho e confiança, por sempre me acolherem e abrirem as portas desta Universidade, desta Disciplina.

Aos funcionários da Disciplina de Odontopediatria da Unifal, Universidade Federal de Alfenas, Ana, Ângela, D. Antônia e D. Georgina, Flávio e José Carlos, pela amizade, carinho, atenção sempre compartilhados com a minha pessoa.

À Secretaria Municipal de Educação das cidades de Alfenas e Areado, por entender e aceitar este trabalho maravilhoso, proporcionando, assim, a sua execução.

Às Diretoras e Funcionárias das Instituições Públicas e Privadas da cidade de Alfenas e Areado, pela colaboração, carinho e confiança na realização deste trabalho.

Às crianças, seus familiares e a todos que contribuíram direta e indiretamente para a realização deste trabalho e deste mestrado. 



\section{RESUMO}

A CPI ainda é considerada um sério problema de saúde bucal. A identificação do risco ao desenvolvimento à cárie em criança baseia-se em informações sobre uma combinação de fatores sóciodemográfico, dietético, higiene bucal e classe social. Sabe-se que estudos epidemiológicos são necessários para se obter dados, a fim de se planejar, executar e avaliar de forma melhor os serviços de atenção odontológica baseada em promoção de saúde. A elaboração de um programa preventivo voltado para a população pré-escolar é de fundamental importância, visto que, são poucos os estudos voltados para esta faixa etária. Portanto, este trabalho, teve como objetivo avaliar clinicamente a saúde bucal de 447 pré-escolares ( 0 a 71 meses de idade), dos Municípios de Alfenas e Areado MG, pertencentes a escolas públicas e privadas, com e sem assistência odontológica através dos índices de cárie ceos, de biofilme visível (IPV) e, de sangramento gengival (ISG). Além disso, foram coletados os dados indicadores de risco à cárie da amostra envolvida através da aplicação de um questionário. Houve um maior número de crianças na rede pública. Observou-se o fenômeno da polarização e o predomínio de CPI na região posterior. O ISG foi igual a 0 para os dois municípios. O teste $t$ de Student mostrou que 0 ceos $(p=0,0326)$, e o IPV $(0,0000)$ entre os dois municípios foram significantes. O IPV entre as crianças com e sem assistência odontológica $(p=0,0000)$ e entre as crianças de escolas públicas e privadas de Areado $(p=0,023)$ foram significantes.

$O$ teste do qui-quadrado mostrou que o gênero masculino $(p=0,00529)$ e a freqüência das visitas ao Cirurgião Dentista $(p=0,0000)$ influenciaram a experiência de CPI significantemente. A Análise de Regressão Linear Múltipla, com um $p=0,000$ e $R^{2}=26 \%$, mostrou significância entre as variáveis independentes: gênero masculino ( $p=0,0013)$, freqüência de escovação $(p=0,0000)$, uso do fio dental $(p=0,0485)$, presença de fumante $(p=0,0020)$ e, nível sócioeconônico $(p=0,0187)$, com a variável dependente (CPI). Para a amostra de 37 a 71 meses dos dois municípios juntos, de acordo com o ceos, observou-se que não houve influência a presença de CPI anterior na experiência de CPI posterior encontrada.

Palavras-Chave: Cárie precoce da infância. Epidemiologia. Placa dentária. Dentição decídua. 



\section{ABSTRACT \\ Clinical evaluation of oral health of preeschool the Alfenas and Areado - MG}

ECC (Early Childhood Caries) is still considered a serious oral health problem. A child caries development risk is identified based on a combination of factors as social-demographic, dietetic, oral hygiene and social class status. It's known that epidemiological studies are necessary to better plan, execute and evaluate services related to deontological health promotion. The elaboration of a preventive program, targeted for preschool is very important as little studies are dedicated to this population. Thus, this work aimed to clinically evaluate the oral health of 447 preschool (from 0 to 71 months old), in the towns of Alfenas and Areado/MG, from public and private schools, with and without deontological assistance. Study was based on dental caries (DMFS), visible plaque (VPI) and gingival bleeding (GBI) indexes. Besides, data collection on caries risk indicators was obtained through a questionary applied to the involved sample. There was a higher number of children from public schools. Polarization phenomenon and the predominance of ECC in the posterior zone were observed. The GBI was equal to 0 for both towns. The t-Student test showed that the dmfs $(p=0,0,26)$ and the VPI $(p=0,0000)$ between the two towns, were significant. In Areado, the VPI among children with and without dental assistance $(p=0,0000)$ and among children from public and private schools $(p=0,023)$, were also significant. The chi-square test showed that male gender $(p=0,00529)$ and the frequency of visits to the dentist $(p=0,0000)$ significantly influenced the ECC experience. The Multiple Linear Regression Analysis with $p=0,000$ and $R^{2}=26 \%$, was significant between the dependent variable (ECC) and independent variables: male gender $(p=0,0013)$, dental brushing frequency $(p=0,0000)$, dental floss usage $(p=0,0485)$, presence of smokers $(p=0,0020)$ and, social-economic status $(p=0,0187)$. Based on sample analysis of a children group from 37 to 71 months of age, for both towns together, according to DMFS, the presence of ECC in the anterior zone did not influenced the ECC in the posterior zone experience.

Key words: Early childhood caries. Epidemiology. Dental plaque. Deciduous dentition. 



\section{LISTA DE ILUSTRAÇÕES}

Gráfico 1 Distribuição de criança por cidade e tipo de escola.

Gráfico 2 Distribuição de criança por faixa etária e o tipo de instituição 82

Gráfico 3 Distribuição porcentual da amostra segundo o gênero. .82

Gráfico 4 Distribuição de crianças de acordo com a experiência de CPI

Gráfico 5 Distribuição da amostra total por faixa etária, quanto experiência de CPI.

Gráfico 6 Distribuição da amostra total quanto ao gênero e a experiência de CPI nos dentes decíduos posteriores 86

Gráfico 7 Distribuição da porcentagem de crianças de acordo com a experiência de CPI nas superfícies dos dentes decíduos posteriores.

Gráfico 8 Distribuição da porcentagem de crianças na amostra total com experiência de CPI e IPV

Gráfico 9 Experiência de $\mathrm{CPI}$ na amostra total, quanto à faixa etária 88

Gráfico 10 Distribuição das crianças da amostra total por faixa etária, quanto à placa visível. 89 



\section{LISTA DE ABREVIATURAS E SIGLAS}

ceos Cariado, extraído, obturado - superfície

ceod Cariado, extraído, obturado - dente decíduo

COPASA Companhia de Água e Saneamento

CEP Comitê de Ética em Pesquisa

CPO-D Cárie precoce da infância

CPI Cárie precoce da infância

CPI-S Cárie precoce da infância severa

IPV I Índice de placa visível

ISG Índice sangramento gengival

IC Intervalo de confiança

NSE Nível sócioeconômico

OMS Organização Mundial de Saúde

SM Estrpetococcus mutans

UNIFAL Universidade Federal de Alfenas

UNIFENAS Universidade de Alfenas

TCLE Termo de Consentimento Livre e Esclarecido

CEP Comitê de Ética em Pesquisa 



\section{LISTA DE TABELAS}

Tabela 1- Distribuição da amostra total por faixa etária, de acordo quanto à experiência de CPI

Tabela 2 - Distribuição da porcentagem de crianças de acordo com a presença ou ausência da experiência de CPI nos dentes decíduos posteriores. 85

Tabela 3 - Experiência de CPI na amostra total, quanto à faixa etária 88

Tabela 4 - Distribuição das crianças amostra total por faixa etária, quanto à placa visível

Tabela 5 - Índices de saúde bucal das crianças entre os dois municípios e parâmetros da análise pelo teste t Student 90

Tabela 6- Índices de saúde bucal das crianças segundo a presença de assistência odontológica e parâmetros da análise pelo teste t Student

Tabela 7- Índices de Saúde Bucal das crianças segundo o tipo de escola no município de Areado

Tabela 8 - Influência do gênero na experiência de cárie, analisada pelo teste do qui-quadrado

Tabela 9 - Influência da freqüência de visitas ao CD, na experiência de cárie, analisada pelo teste do qui-quadrado

Tabela 10- Fatores indicadores do risco à cárie com relação significante com a experiência de $\mathrm{CPI}$, indicados pela análise de Regressão Linear Múltipla. .94

Tabela 11 - Distribuição das crianças de 37 a 71 meses de acordo com o índice de cárie, dos municípios de Alfenas e Areado juntos 95 



\section{SUMÁRIO}

1 INTRODUÇÃO 15

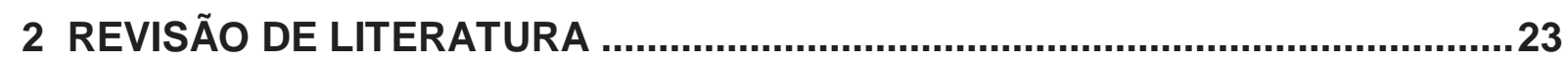

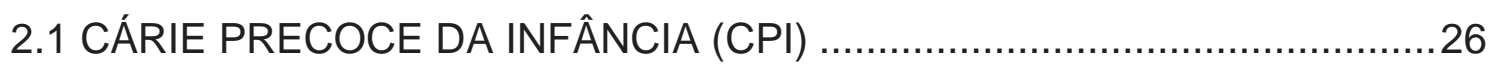

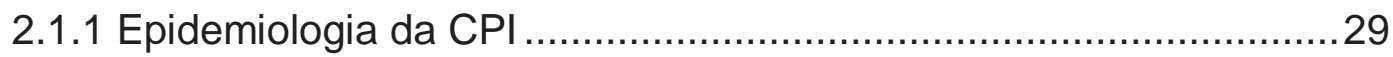

2.1.1.1 Estudos Isolados no Brasil - Região Norte..........................30

2.1.1.2 Estudos Isolados no Brasil - Região Nordeste ......................31

2.1.1.3 Estudos Isolados no Brasil - Região Centro-

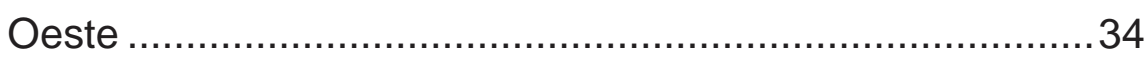

2.1.1.4 Estudos Isolados no Brasil - Região Sudeste ......................35

2.1.1.5 Estudos Isolados no Brasil - Região Sul .............................38

2.1.1.6 Estudos isolados Internacionais ......................................40

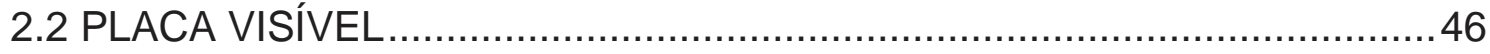

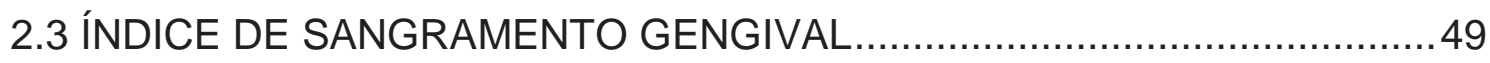

2.4 FATORES DE RISCO E INDICADORES DE RISCO PARA A CÁRIE DENTÁRIA EM PRÉ-ESCOLARES .........................................53

3 PROPOSIÇÃO .65

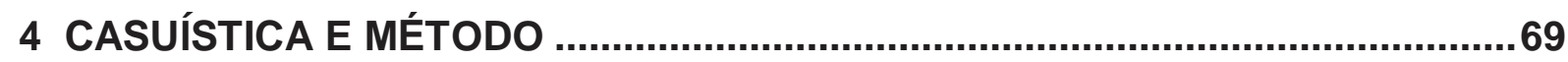

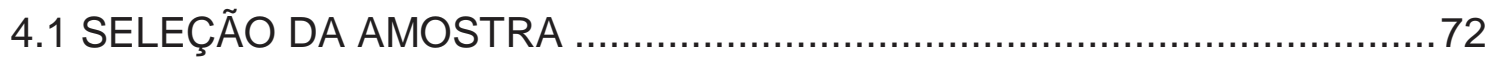

4.2 CONDIÇÕES DOS EXAMES CLÍNICOS …………................................73

4.3 MATERIAL USADO PARA A COLETA DOS DADOS..................................74

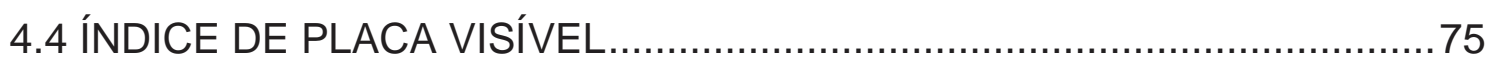

4.5 ÍNDICE DE SANGRAMENTO GENGIVAL.............................................

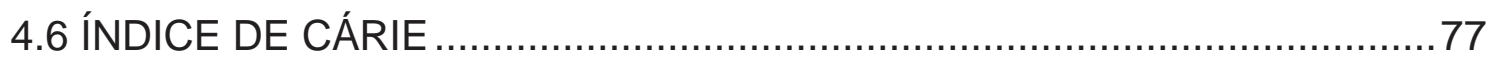

4.7 QUESTIONÁRIO DE AVALIAÇÃO DOS FATORES INDICADORES DO RISCO À CÁRIE ......................................................77

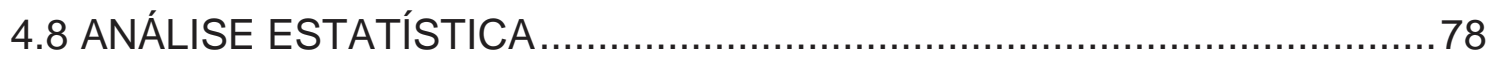



5 RESULTADOS.

5.1 ANÁLISE DESCRITIVA DA AMOSTRA TOTAL: ALFENAS

E AREADO

5.2 ANÁLISE DESCRITIVA DA AMOSTRA TOTAL:

EXPERIÊNCIA DE CPI 83

5.3 ANÁLISE DESCRITIVA DOS ÍNDICES DE SAÚDE BUCAL

NA AMOSTRA TOTAL (0 a 71m): Ceos, IPV e ISG

5.4 ANÁLISE ESTATÍSTICA DOS ÍNDICES DE SAÚDE

BUCAL: ceos e IPV.

5.5 ANÁLISE ESTATÍSTICA DA INFLUÊNCIA DE FATORES

INDICADORES DO RISCO À CÁRIE, SOBRE O Ceos NA

AMOSTRA TOTAL (0 a $71 \mathrm{~m})$

5.6 ANÁLISE ESTATÍSTICA DOS ÍNDICES DE SAÚDE

BUCAL NA AMOSTRA PARCIAL (37 a $71 \mathrm{~m}$ ) .94

6 DISCUSSÃO 97

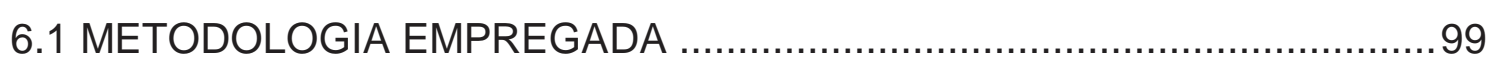

6.2 DISCUSSÃO DOS RESULTADOS ENCONTRADOS ................................104

7 CONCLUSÃO 121

REFERÊNCIAS 125

ANEXOS 

1 Introduçãa 



\section{INTRODUÇÃO}

A avaliação das condições de saúde bucal da população deve ser uma preocupação constante não apenas das autoridades de saúde, mas de todos os setores da sociedade, que participam direta ou indiretamente no planejamento e condução de pesquisas nesta área do conhecimento. (POLETTO, 1993).

Estudos epidemiológicos é a única forma de proporcionar uma visão do estado de saúde bucal e necessidades de tratamento de uma população e, também, avaliar as possíveis relações entre os fatores ambientais e a prevalência de cárie. (POLETTO, 1993). Também são propostas destes estudos controlarem as mudanças nos níveis ou padrões da doença. (BÖNECKER et al., 2000).

Alguns estudos verificaram que houve um declínio na prevalência de cárie dentária em crianças. (DINI, 2000; BONECKER, 2000). Eles fornecem uma base sólida para as estimativas das condições atuais de saúde bucal de uma população, bem como vislumbram as futuras necessidades de atenção à mesma. Através desses levantamentos, torna-se possível o desenvolvimento de programas municipais, regionais ou nacionais de saúde bucal, bem como o planejamento da quantidade e do tipo de profissionais necessários para atender as necessidades de cada município. (OMS, 1991).

O planejamento, o controle e a execução das ações básicas de saúde dependem da coleta de informações na comunidade-alvo, onde só o estudo epidemiológico seriamente dirigido pode oferecer. Portanto, decisões políticas em saúde coletiva devem se pautar em proporcionar ao indivíduo todas as condições possíveis para evitar a doença e promover a saúde em todos os níveis. E para que haja decisões acertadas é necessária à análise de dados epidemiológicos confiáveis e objetivos. (SARTORI, 1999).

Apesar da possibilidade de prevenção, a cárie continua sendo a doença de origem bucal mais prevalente na população e, sendo assim, considerada um problema de saúde pública. (BASTOS, 2006). A identificação de fatores coletivos de risco à cárie dentária em idade pré-escolar surge como instrumento forte para 
possibilitar a prática odontológica, a adequação dos cuidados de saúde bucal e a reorientação dos gastos em atenção à saúde.

Diversos fatores de risco devem ser considerados na avaliação do risco de cárie, entre eles a quantidade de placa bacteriana presente nas superfícies dentárias, o tipo de bactérias presentes, a freqüência de ingestão de carboidratos fermentáveis, a secreção salivar, a capacidade-tampão da saliva e a presença de fluoretos. (ARAl et al., 2003).

Além disso, a falta de informação dos pais sobre a necessidade de higiene dos dentes que estão irrompendo, e sobre o potencial cariogênico do leite em horários freqüentes, faz com que eles permitam que seus filhos adormeçam durante ou logo após a alimentação. Desta forma, o leite estagnado sobre os dentes, acrescido de uma redução do fluxo salivar durante o sono, proporciona um excelente meio de cultura para microrganismos acidogênicos na cavidade bucal. (ABDO, NUNES, SALLES, 1998).

Scavuzzi et al. (2007) realizaram um estudo longitudinal de cárie dentária em 217 crianças de 12 a 30 meses, na cidade de Feira de Santana, BA. De um modo geral, a porcentagem de crianças com cárie aumentou de 6,4\% para 19,9\% em um período de um ano, com progressão geométrica da doença. A dieta cariogênica estava fortemente associada com a presença da cárie de estabelecimento precoce.

A maioria dos estudos epidemiológicos realizados no Brasil descreve a prevalência e severidade da cárie em escolares. A condição de saúde bucal de préescolares não tem sido documentada na mesma extensão que a saúde bucal do escolar. Isso ocorre, provavelmente, porque a dentição decídua não tem sua importância tão considerada quanto a permanente. (BARBOSA et al., 2005).

Embora seja observado o declínio na prevalência de cárie dentária em crianças e adolescentes, a presença dessa doença nos primeiros anos de vida é um assunto muito preocupante em virtude da alta prevalência e das sérias repercussões médicas, emocionais e financeiras proporcionadas pela destruição dentária. (VOLSCHAN; SOARES, 2003). 
Na primeira infância, a criança possui uma relação de dependência com o adulto, inserindo-se dentro do contexto sócio-cultural da família, o qual tem forte influência na definição do padrão dietético e nas medidas de limpeza da boca a serem adotadas. (CERQUEIRA et al, 1999).

Como em outras doenças, a cárie dentária é socialmente determinada. E o impacto da assistência odontológica na redução de sua prevalência é bastante limitado. O ponto em comum em todos os países que experimentaram redução em seus índices de cárie é a melhoria nas condições globais de saúde e qualidade de vida. A condição social tem sido enfatizada como importante determinante da situação de saúde bucal. (BARBOSA et al., 2007).

O entendimento de que a Odontologia sob a óptica tradicional não promovia saúde favoreceu conseqüentemente, nas últimas décadas, embora de forma discreta, determinadas mudanças em sua prática. Dentro desse novo paradigma, tem havido uma ênfase crescente no desenvolvimento de estratégias preventivas, caracterizadas pelo início da atenção à criança o mais precocemente possível (CERQUEIRA, 1999), já que foi constatado que a cárie dentária afeta precocemente a criança no Brasil. (BRASIL, 2004).

No Projeto Nacional sobre saúde bucal "SB Brasil 2003" (BRASIL, 2004), do Ministério da Saúde, em todo o Brasil foram examinadas 12.117 crianças com idade entre 18 e 36 meses, com 73,15\% destas sem cárie dentária. Nas crianças com 5 anos de idade examinadas, 40,62\% não apresentavam cárie dentária. Em média, uma criança brasileira com 3 anos de idade ou menos, já possui, pelo menos, um dente com experiência de cárie dentária (ceod=1,1). Aos 5 anos, essa média aumenta para quase 3 dentes (ceod=2,8). Na maioria dos casos, o componente cariado é responsável por mais de $80 \%$ do índice na idade de 5 anos, e mais de $90 \%$ nas crianças de 18 a 36 meses. Entre as regiões brasileiras, verificou-se que a proporção de dentes cariados é sensivelmente maior nas regiões Norte e Nordeste.

Sabe-se também que o controle da placa bacteriana continua sendo o método mais eficaz para a diminuição da atividade cariogênica, associada ao uso diário de fluoretos e ao controle da dieta alimentar. (MEDEIROS et al., 1998). 
Os índices têm sido desenvolvidos para quantificar e acessar informações clínicas. Eles descrevem condições ou alterações nos tecidos moles e duros da cavidade bucal. (CARTER; BARNES, 1974).

Os índices que quantificam placa e inflamação gengival em diferentes regiões de cada superfície dentária são bastante eficazes e tem a vantagem de oferecerem informações mais acuradas das variáveis clínicas, além de serem mais sensíveis na avaliação das mesmas, pelo fato delas serem quantificadas em cada local ou em escala incremental. (GALGUT, 1999). Ressalta-se ainda que os indicadores IPV e ISG não representam a história pregressa da doença como e ceod, indicando características ainda iniciais das doenças cárie e periodontal. (SANTOS et al., 2004).

A ocorrência de superfícies dentárias recobertas por placa, avaliada pelo índice de placa visível (IPV) é um parâmetro clínico relevante tanto para o CirurgiãoDentista, como para o paciente avaliar o seu grau de higiene bucal. (AINAMO; BAY, 1975). A aplicação deste índice é uma medida interessante para o estímulo ao controle de placa bacteriana; o qual é uma das estratégias para prevenção da cárie dentária (BARBER; WILKINS, 2002), pois é conhecida a relação de causa-efeito entre as ambas. Isso foi demonstrado por Holst, Martensson e Laurin (1997), após avaliarem crianças, entre 1 e 4 anos. Eles observaram que o fator de risco de cárie mais freqüente encontrado após dois e três anos foi a falta de higiene bucal com presença de placa visível. Mais recentemente, Couto et al. (2005) também encontraram uma correlação positiva entre IPV com as variáveis mancha branca, ceod e ceod modificado (inclusão da mancha branca) em crianças de 0 a 36 meses.

O índice de sangramento gengival é empregado em levantamentos de grupos populacionais para registrar as alterações gengivais em crianças de 5 anos de idade. (PEREIRA, 2003). O sangramento gengival é uma indicação precoce de gengivite e periodontite. (CARTER; BARNES, 1974). Embora os microrganismos responsáveis pela gengivite sejam diferentes daqueles primariamente responsáveis pela cárie, a presença da gengivite é um indicador da pobre e não freqüente prática de higiene bucal e tem sido associado com a progressão da cárie. (AAPD, 2007). Além disso, o ISG também pode apresentar uma correlação positiva com o IPV, como demonstrado por Feldens et al., (2006), após avaliarem 490 crianças entre 3 e 5 anos. 
A remoção de biofilme dental é um exercício que requer habilidade e motivação e, quando a prática é realizada em crianças, o nível de dificuldade é sensivelmente aumentado. (MOURA et al., 2009). Ao avaliarem crianças entre 3 e 6 anos, os autores verificaram que, quanto maior a idade da criança, mais alto o ISG.

Os problemas bucais normalmente encontrados na criança pré-escolar podem variar em função de uma grande gama de fatores, locais, ambientais, individuais, etc, que, portanto necessitam estudo para uma melhor compreensão da importância de cada um bem como da interação entre eles. Assim, é de fundamental importância conhecer aqueles fatores mais envolvidos com o risco da cárie dentária e doença periodontal em pré-escolares, com a finalidade de agrupar o maior número de dados possível do nível de saúde dessa população a fim de que medidas eficazes e eficientes possam ser tomadas com o objetivo de permitir a elaboração de uma estratégia preventiva e restauradora visando uma melhora do nível de saúde dessa faixa etária, bem como o controle futuro das doenças bucais mais comuns na infância. 

2 Revisão de Literatura 



\section{REVISÃO DE LITERATURA}

Nas últimas décadas, tem-se observado uma tendência de queda nos índices de cárie no Brasil e em outros países. Muitos fatores são apontados como possíveis causas do declínio dessa doença: a adição de flúor na água de abastecimento público, o emprego de dentifrícios fluoretados em larga escala e modificações no padrão e quantidade de consumo de açúcar, associados à melhoria nas condições de vida; e maior acesso e atenção em saúde bucal coletiva e ampliação das ações de promoção e educação em saúde bucal. A cárie dentária, entretanto, ainda permanece como um grande problema de saúde pública, no Brasil e na maior parte do mundo. (BARBOSA et al., 2007). Apesar de todos os esforços no combate à cárie dentária ela ainda é um fator preocupante, atingindo milhares de pessoas, principalmente as crianças em fase pré-escolar. (LEITE et al., 2004).

A cárie dentária ainda tem sido considerada uma doença da civilização refletindo o fato de que a mesma ocorre tanto em países desenvolvidos quanto em países em desenvolvimento. A falta de informação, ainda faz com que as pessoas pensem que o tratamento para crianças só começa com a erupção do primeiro dente e, mesmo assim, muitos acreditam que a doença cárie na dentição decídua não constitui um problema. (MEDEIROS et al., 1998).

É de extrema importância conhecer e controlar os fatores indicadores do risco à cárie, no bebê e na criança pré-escolar, para uma efetiva prevenção dessa doença bucal, tão freqüente. A dificuldade de conhecê-los todos, é porque a cárie é uma doença multifatorial, com interações complexas entre os fatores. Assim por exemplo, é sabido que microorganismos, principalmente Streptococcus mutans, processam resíduos de uma dieta alimentar rica em sacarose, os quais, aliados a uma deficiente higiene bucal, e o uso de mamadeira ou amamentação noturna sem posterior higienização, iniciam o desenvolvimento dessas lesões. (MEDEIROS, et al., 1998).

O declínio da cárie dentária tem sido acompanhado pela polarização da doença nos grupos menos privilegiados. (BARBOSA et al., 2007). Essa polarização da cárie dentária, fenômeno onde a prevalência da patologia acomete com maior 
freqüência grupos sociais menos favorecidos sócio-economicamente, fortaleceu mais intensamente as preocupações no controle e prevenção da cárie em comunidades carentes, bem como suas repercussões. (FEITOSA; COLARES, 2004). A experiência da doença dentária é diferenciada de acordo com a classe, deixando marcas bucais da iniqüidade e prejudica a auto-estima e inclusão social tanto da criança, quanto do adulto. (MOREIRA et al., 2007).

Naidoo e Myburgh (2007), cárie, é uma doença mundial, com poucas populações isentas de seus efeitos. Há uma necessidade de identificar grupos de risco com precisão e prevenção em idades jovens. Informações sobre nutrição, acesso ao flúor e utilização de açúcar, também são preocupações com a saúde oral.

\subsection{CÁRIE PRECOCE DA INFÂNCIA (CPI)}

A cárie precoce da infância (CPI) (early childhood caries- ECC) é definida como a presença de um ou mais dentes decíduos cariados (lesões com ou sem cavidade), perdidos (devido à cárie), ou restaurados, em crianças com 71 meses de idade ou menos. Em crianças mais jovens que 3 anos de idade, qualquer sinal de cárie em superfície lisa é indicativa de cárie precoce da infância - severa (CPI-S). Entre 3 a 5 anos, uma ou mais superfícies com cavidade, perdidas (devido à cárie) ou restauradas, em superfície lisa nos decíduos da região anterior maxilar, ou superfície cariada, perdida ou restauradas com escore $\geq 4$ (na idade de 3 anos), escore $\geq 5$ (idade de 4 anos), ou escore $\geq 6$ (idade de 5 anos), constituem a CPI-S. (AAPD, 2007).

A CPI está associada a um consumo prolongado de líquidos contendo carboidratos fermentáveis, segundo a Academia Americana de Odontopediatria (American Academy of Pediatric Dentistry, AAPD, 2007, 2009). É uma patologia que acomete quase que exclusivamente crianças de grupos socioeconômicos menos favorecidos em países desenvolvidos e em desenvolvimento. (REISINE; DOUGLAS, 1998). 
De acordo com Ripa (1988), os dentes mais afetados pela cárie são os quatros incisivos superiores decíduos, apresentando lesões bastante severas, podendo envolver ainda os caninos, primeiros e segundos molares, com padrão de destruição simétrico. Não afeta incisivos inferiores, devido à proteção oferecida pela língua. A cronologia do ataque da cárie está relacionada com a época de erupção dos dentes e permanência do hábito de mamar por longo tempo. O aspecto clínico inicial da CPI consiste em uma mancha branca ao redor da cervical dos dentes, que progride para uma cavidade a qual circunda o colo do dente de coloração marrom ou preta, sendo o leite o principal agente etiológico, sobretudo quando associado à sacarose.

De acordo com Fritsher et al. (1999), o padrão e o grau de transmissibilidade microbiana dependem de diversos fatores como o nível de infecção dos pais, babás ou qualquer pessoa que cuida das crianças, a freqüência do contato, a dieta oferecida e o próprio estado de imunidade individual.

Quando a CPI se instala, se não controlada, pode atingir estágios severos, com a destruição total da coroa dentária, repercutindo de maneira negativa na vida da criança. Além da presença de dor, a perda de estrutura dentária promove comprometimento da estética, mastigação, fonação e deglutição, afeta o desenvolvimento social da criança, que poderá apresentar dificuldade de relacionamento, comprometendo o desempenho escolar e favorecendo as faltas à escola. (FEITOSA; COLARES, 2003). É também uma condição debilitante, com tratamentos demorados, dispendiosos e estressantes, tanto para a criança e seus pais, quanto para o profissional que se depara com a difícil tarefa de restabelecer uma condição bucal de saúde. (SILVA et al., 2001).

As características destrutivas deste tipo de cárie, atingindo uma idade precoce e em alta prevalência, torna um padrão de cárie que requer um cuidado especial. (DAVIDOFF et al., 2005). O diagnóstico precoce das lesões iniciais (mancha branca), ainda em estágio reversível, e a avaliação dos fatores determinantes torna-se fundamentais no estabelecimento de um tratamento mais simples, menos invasivo e de menor custo, envolvendo mudanças de comportamento com relação à higiene bucal e à dieta bem como o uso de flúor. (BARROS et al., 2001). 
As localizações mais freqüentes de lesões de CPI são as superfícies vestibulares e palatinas dos incisivos e primeiros e segundos molares, principalmente inferiores. Estas lesões têm aspecto clínico de cor esbranquiçada e consistência amolecida. (MEDEIROS et al., 1998).

Esse padrão da cárie dentária é considerado um problema de saúde pública, e por esse motivo, é necessário que os profissionais de saúde conscientizem a população sobre o mesmo e sua relação com a qualidade de vida. (VOLSCHAN; SOARES, 2003).

Na etiologia da CPI há tanto a influência de questões biológicas quanto das dimensões socioculturais, podendo-se afirmar que a cárie é uma doença determinada biologicamente e condicionada socioculturalmente. (VOLSCHAN; SOARES, 2003).

Gussy et al (2006), revisou a etiologia e prevenção da doença cárie em crianças com idade pré-escolar. Os estudos foram limitados e incluindo crianças de 5 anos. A CPI manifesta de forma virulenta e de freqüência rápida, que pode ser devido vários fatores como o substrato, microorganismo, superfície do dente, saliva, placa e fatores sócio-culturais. Evidência contemporânea sugere que intervenções eficazes, devem ocorrer nos primeiros 2 anos de vida de uma criança e o atendimento odontológico antes da idade de 2 anos é incomum, no entanto, o contato com outros profissionais da saúde é alta.

No Brasil, constatou-se entre 1995 e 1997 uma redução na prevalência da cárie dentária em crianças com menos de três anos de idade, (ceos= 0,2 para ceos=0,0, entre 5-12 meses; ceos=1,1 para ceos=0,3, entre 12-24 meses; e ceos= 3,7 para ceos=1,7 entre 24-36 meses, com a inclusão de cárie inicial (mancha branca). (BONECKER et al., 2000). Apesar desses dados, o perfil epidemiológico da cárie em algumas regiões do país, pode ser considerado bastante crítico principalmente por se tratar de crianças pequenas. Scavuzzi et al. (2007) mostraram que $20 \%$ de crianças entre 12 e 30 meses de idade apresentaram nova lesão após um ano. Entre aquelas com lesões iniciais, a presença de cárie quase que dobrou durante os exames, nesse intervalo. A prevalência de cárie aumentou 3 vezes no intervalo de um ano. 
Simratvir et al (2009), relata que a CPI é uma doença que acomete até mesmo os dentes em erupcção na cavidade oral. Medidas preventivas e terapêuticas são essenciais para o controle da condição oral.

\subsubsection{Epidemiologia da CPI}

Adquirir um conhecimento detalhado da distribuição da cárie e seus determinantes biopsicossociais é o passo inicial e indispensável para o planejamento de programas de saúde bucal. Assim, incluir variáveis relacionadas ao nível sócio-econômico torna-se fundamental bem como, utilização de outros índices e indicadores que não apenas o ceod. (HOFFMANN et al., 2004).

Durante as últimas décadas em que ocorreu o declínio da cárie dentária, várias estratégias e ações foram desenvolvidas para controlar a doença, com inúmeros estudos que avaliaram o impacto de um ou vários fatores etiológicos. É muito difícil determinar, o que de fato ocorreu, devido à quantidade de fatores etiológicos diretos ou indiretos envolvidos. Além disso, mesmo que fosse possível descrever todos os fatores envolvidos e a condição de saúde bucal de uma população, não seria possível extrapolar esses resultados para uma outra população que vive em condições diferentes. (BÖNECKER, 2005).

O tipo de escola freqüentada é um indicador confiável de condição sócioeconômica em ambientes urbanos, pois crianças de famílias com altos salários geralmente freqüentam escolas particulares, sendo o oposto de famílias com baixo nível sócio-econômico, as quais freqüentam principalmente o sistema público escolar. (IRIGOYEN et al., 2002). Na maioria dos estudos verificou-se a prevalência de cárie em escolares do ensino público. (DINI, 1999; NARVAll, 2000; BASTOS, MAGALHÃES, SILVA, 2006;). Entretanto, também é relevante que sejam investigadas as condições de saúde bucal das crianças de escolas particulares, pois os levantamentos epidemiológicos realizados nas três últimas décadas já mostraram uma desigualdade de experiência de cárie entre as classes sociais. (TRAEBERT, 2001; CANGUSSU, 2001; TINANOFF, 2002). 
No Projeto Nacional sobre saúde bucal "SB Brasil 2003" (BRASIL, 2004), do Ministério da Saúde, um dos objetivos específicos foi o de estimar a prevalência de cárie dentária para a população de 18 a 36 meses e 5 anos de idade. Em todo o Brasil, foram examinadas 12.117 crianças com idade entre 18 e 36 meses, e 73,15\% não apresentavam cárie dentária. Também foram examinadas 26.641 crianças com 5 anos de idade e 40,62\% não apresentavam cárie dentária. Em média, uma criança brasileira com 3 anos de idade ou menos, já possui, pelo menos, um dente com experiência de cárie dentária (ceod=1,1). Aos 5 anos, essa média aumenta para quase 3 dentes (ceod =2,8). Na maioria dos casos, 0 componente cariado é responsável por mais de $80 \%$ do índice na idade de 5 anos, e mais de $90 \%$ nas crianças de 18 a 36 meses. O ceod médio brasileiro para essa faixa etária mais nova foi de 1,07. Contudo, entre as regiões brasileiras, verificou-se que a proporção de dentes cariados é sensivelmente maior nas regiões Norte e Nordeste. Nas crianças de 18 a 36 meses da região Norte, o ceod foi de 1,34 e, na região Nordeste foi de 1,00. Na região Sudeste, o ceod foi de 0,95; na região Centro-Oeste foi de 0,80 e, na região Sul o ceod foi de 1,04.

Antunes, Peres Frazão (2006), estudos epidemiológicos de cárie dentária, em especial têm sido considerados informações sobre condição socioeconômica, acesso a serviços odoontológicos, oferta de flúor nas águas de abastecimento público, características de higiene bucal e hábitos alimentares.

\subsubsection{Estudos Isolados no Brasil - Região Norte}

Na cidade de Manaus, Maia et al. (2007) realizaram um estudo da prevalência de cárie, através do índice ceod, em 120 crianças (ambos os gêneros) de 0 a 60 meses. A prevalência média de cárie na população estudada atingiu 36,7\%. A faixa etária de maior prevalência de cárie foi a de 49 a 60 meses (60,9\%), correspondendo quase ao dobro da presença de cárie na faixa de 37 a 48 meses (37\%) e ao triplo da faixa entre 25 a 36 meses (21,7\%). Na faixa entre 49-60 meses, o índice ceod foi de 3,10; enquanto que na faixa etária entre 0-12 meses foi de 0,00. De acordo com os autores, $82,5 \%$ das crianças nunca haviam ido ao dentista, e 
75\% delas necessitavam de tratamento restaurador. É relevante salientar que a população estudada não recebia água de abastecimento público fluoretada.

Na cidade de Macapá, AP, foi realizado por Gradella et al. (2007) um estudo epidemiológico da cárie em crianças de 5 a 59 meses de idade. De acordo com os autores, a água de abastecimento da cidade é fluoretada (0,7 ppm), porém, segundo a Secretaria de Saúde da cidade, em alguns bairros, não chega a 0,24 ppm. Um total de 1.137 crianças, 602 meninos e 535 meninas foram examinadas em 15 Unidades Básicas de Saúde (UBS) por 15 diferentes equipes de trabalho. Os índices utilizados para avaliação da cárie foram os ceod e ceos cujos valores encontrados foram respectivamente de 2,07 e 3,45. O aumento da prevalência da cárie ocorreu com o aumento da faixa etária, com a população estudada apresentando uma prevalência média de 42,6\%.

\subsubsection{Estudos Isolados no Brasil - Região Nordeste}

Cerqueira et al (1999), realizaram um estudo da prevalência de cárie em crianças de 0 a 36 meses na cidade de Natal, RN, quando a água de abastecimento ainda não era fluoretada. Os autores avaliaram 437 crianças (ambos os gêneros), em um dia Nacional de Campanha de Multivacinação e verificaram um maior aumento da prevalência de cárie entre o primeiro e o segundo ano de idade, do que em relação ao segundo e terceiro ano de vida, através do índice ceod. Verificaram também uma correlação positiva entre a alta ingestão de açúcar e a alta prevalência de cárie. As crianças com menos de seis meses não apresentaram cárie (ceod=0). Já nas maiores de seis meses, constatou-se a presença de manchas brancas, enquanto que a presença de cavidade foi registrada em crianças com idade a partir de 12 meses. Em relação à faixa etária acima de 24 meses, foi evidente o aumento dos índices ceod $(<1)$ e ceos $(>1)$, considerando ou não a mancha branca.

Barros et al. (2001) avaliaram, através do ceod, a prevalência de cárie em 340 crianças (54\% meninos e 45,6\% meninas), de 0 a 30 meses em creches de Salvador, BA, que possui água de abastecimento fluoretada. As creches não 
possuíam atendimento odontológico e as crianças pertenciam a classes de baixa renda, pois $72,5 \%$ dos pais ou responsáveis recebiam até um salário mínimo. Foi encontrada uma prevalência de cárie de 55,3\%, quando todos os estágios da lesão foram considerados. Quando apenas manchas brancas ativas foram incluídas, $49,7 \%$ das crianças mostravam-se afetadas, e 17,6\%, quando se avaliaram apenas as lesões com cavidade. Observou-se também o aumento da prevalência de cárie estatisticamente significante $(\mathrm{p}<0,01)$ proporcional à idade e ao número de dentes irrompidos. Os dentes mais afetados foram os incisivos centrais e laterais superiores, seguidos pelos molares inferiores, molares superiores e caninos superiores. O hábito do aleitamento noturno era praticado por $55,46 \%$ das crianças ( $n=127)$ e a associação entre este hábito e a prevalência de cárie não foi estatisticamente significante. Outros fatores indicadores de risco avaliados foram exposição a fluoretos, orientação e realização de higiene bucal e presença de biofilme. A associação da presença de fluoretos com prevalência da cárie não pôde ser avaliada pela pequena porcentagem da população exposta. $O$ fator higiene bucal, avaliado pelo aumento da quantidade de biofilme, mostrou associação positiva com a presença de cárie. Com relação à experiência de cárie (ceod), quando consideradas as lesões incipientes (mancha branca), ela foi de: 0,35 para as crianças de 0-12 meses; 1,32 para as crianças de 13-24 meses e, de 2,38 para as crianças de 25-30 meses.

Em um estudo transversal realizado por Feitosa e Colares (2004), em 861 crianças (449 meninos, 52,0\% e 412 meninas, 42,90\%), com 4 anos de idade, matriculadas em escolas infantis da cidade de Recife, PE, pertencentes a famílias de baixo nível sócio-econômico, verificaram que 27 delas (3,10\%) apresentavam 1 ou mais dentes indicados para extração. Do total de 405 crianças que apresentavam cárie (47\%), apenas $13,6 \%$ haviam recebido algum tratamento restaurador. Neste estudo, em que foi considerada cárie, a presença de cavidade, o ceod médio foi de 2,06 . Um porcentual de $8,94 \%$ das crianças apresentou cárie em um grau bastante severo, afetando os quatro quadrantes com comprometimento de, no mínimo, 1/3 da coroa de qualquer incisivo e quatro molares com lesão de cárie clinicamente visível. É importante considerar que a cidade de Recife, no ano de 2004, não apresentava água de abastecimento fluoretada. 
Silva et al (2006), verificou a prevalência e os possíveis indicadores de risco para a doença cárie dentária em 150 fichas de prontuários das crianças de 2 a 6 anos (ambos os gêneros), na Clínica de Odontologia Preventiva da UFPB. A amostra foi dividida em dois grupos: crianças sem cárie (ceo- $d=0, n=60$ ) e com cárie (ceo- $d>0$ e $n=90$ ). A prevalência aumento conforme a idade (aos 4 anos ceod- $=4,0$ ). Os dentes mais afetados foram os incisivos superiores (quase 100\%) e molares inferiores (pouco mais de 100\%). Em relação aos indicadores destacou-se a frequência de escovação $(p<0,05)$, apresentando relação com a doença cárie $(54,4 \%)$.

Scavuzzi et al. (2007), em um estudo longitudinal prospectivo realizado com 186 crianças entre 12 e 30 meses na cidade de Feira de Santana, BA, observaram diminuição da prevalência de cárie. No exame inicial das mesmas, 93,5\% apresentaram ceos $=0$. Porém, após o período de um ano, essa porcentagem caiu para $80,1 \%$ e, 2,7\% e 8,6\% com ceos entre 1 e 2 ; e, 3,8\% e 9,1\% ceos igual ou superior a 3. De um modo geral, a porcentagem de crianças com cárie aumentou de $6,4 \%$ para $19,9 \%$, quase 3 vezes mais, neste período.

Melo et al (2009), em um estudo transversal, determinaram a prevalência e gravidade de cárie em 1113 crianças de 18-36 meses (49,7\% meninos e $50,3 \%$ meninas) e 5 anos (52,09\% meninos e 48,0\% meninas), cadastradas no Programa Saúde da família do distrito Sanitário IV/ Recife, em 2006 e pertencentes a famílias com renda familiar aproximadamente de um salário mínimo. A prevalência de cárie aos $18-36$ meses foi de $26,9 \%$ e ceo-d de 0,987 , enquanto que para a idade de 5 anos foi de $60,6 \%$ e ceo-d de 2,85. Aos 18-36 meses, num pólo $25 \%$ das crianças tinham entre 1 a 19 dentes cariados, perdidos ou obturados e num outro pólo $75 \%$ estavam livres de cárie (ceo-d=0), sendo que $21 \%$ concentraram valores do índice entre 2 a 19 dentes com experiência de cárie. Aos 5 anos, cerca de 25\% das crianças apresentaram alta gravidade de cárie com valores do ceo-d entre 5 a 14 dentes atacados pela doença. Acometimento precoce, altas prevalências e a polarização da cárie foram encontradas neste trabalho.

Em um estudo transversal, Paredes et al (2009), avaliou a prevalência de cárie e sua associação com alguns fatores sociais e comportamentais em crianças 410 prontuários de crianças de 3 a 13 anos de idade da cidade de João Pessoa PB. 
Elas foram dividias em 3 anos-grupos: $\mathrm{G} 1$ - 3-5 anos $(\mathrm{n}=111$, ceod=2,38), G2 - 6-9 anos $(n=165$, ceod=2,97, ) e G3 - 10-13 anos $(n=134$, ceo- $d=0,89)$. Cerca de 32,7\% das crianças estavam livres de cárie. 44,45 a escovação foi de 3 ou mais vezes ao dia, $61,9 \%$ sem assistência, 73,1\% o não uso do fio dental e $97 \%$ consumo de açúcar entre as refeições. Houve uma elevada prevalência da doença cárie e específicas associações com alguns fatores de risco sócio-econômicos e comportamentais.

\subsubsection{3 - Estudos Isolados no Brasil - Região Centro-Oeste}

Freire, Melo, Silva em 1996, realizaram um estudo para avaliar a presença de cárie dentária nas crianças em idade pré-escolar em Goiânia- GO). A população estuda foi de 0 a 6 anos de idade num total de 2.267 crianças (1.190 meninos e 1.077 meninas), sendo de creches públicas (28,2\% de baixo NSE) e privadas (48,38\%, de maior NSE). A média de CPOD e porcentagem de crianças livres de cárie foi de 0,09 (96,4\%) com um ano ou menos, 0,40 (87,3\%) com 2 anos, 14 $(69,9 \%)$ com 3 anos, 2,18 (49,5\%) com 4 anos 3,18 (36,1\%) com 5 anos, 3,94 $(29,4 \%)$ com idade de 6 anos respectivamente. A prevalência de cárie foi maior nas crianças que freqüentavam creches públicas $(p<0,05)$. Os resultados indicam que 0 social tem influência na experiência de cárie e que programas preventivos e educativos devem ser desenvolvidos.

Na cidade de Cuiabá (MT), Volpato e Figueiredo (2005), realizaram um estudo transversal em crianças de 0 a 5 anos. Os autores avaliaram 934 prontuários (ambos os sexos), de uma clínica municipal que pertenciam ao Programa de Atendimento Odontológico Precoce da Clínica Odontológica do Verdão, Município de Cuiabá, entre os anos de 1996 e 1998. Verificaram que a maioria das crianças atendidas estava na faixa etária ente 0 e 36 meses (92,93\%), e também, que a prevalência da cárie foi diretamente proporcional ao aumento da faixa etária. A maior prevalência de cárie ocorreu na faixa de 43 meses ou mais, com $87,5 \%$ das crianças afetadas, sendo que 93,96\% das crianças entre 0 a 6 meses não apresentaram cárie. 
Em um estudo transversal de saúde bucal realizado na cidade de Goiânia no ano de 2001, Freire et al (2009), avaliou 536 crianças (ambos os sexos) de 3 a 6 anos que freqüentavam centros municipais de educação infantil beneficiados por um programa odontológico municipal (Grupo 1, $n=275$ ) e creches estaduais sem programa odontológico (Grupo 2, $n=261$ ). Foram realizadas atividades clínicas, preventivas, educativas com ênfase no tratamento curativo. Observou-se que não houve diferença entre os dois grupos em relação à prevalência de cárie $(58,5 \%$ com assistência odontológica e 64,8\% sem assistência odontológica) e índice de ceo-s (2,32 e 2,26, respectivamente). O número de superfícies restauradas apresentou diferença estatisticamente significante para o Grupo 1 (0,29 e 0,21, p=0,040).

\subsubsection{4 - Estudos Isolados no Brasil - Região Sudeste}

Em relação à região Sudeste, no estado de Minas Gerais, na cidade de Alfenas, em 1997, que possui água de abastecimento fluoretada, foi realizado um estudo sobre a prevalência de cárie em 550 alunos (ambos os sexos), na faixa etária de 5 a 14 anos, estudantes de escolas públicas e particulares utilizando 0 índice ceod e CPOD. O valor médio do ceod aos 5 anos foi de 2,56 $( \pm 3,11)$, e aos 6 anos, de 2,61 ( $\pm 3,62)$. A média de crianças livres de cárie aos 5 anos foi de 43,64\%, e aos 6 anos, de 45,45\%. (SARTORI, 1999). De acordo com o autor, a mediana acusou que $50 \%$ da amostra aos 5 anos de idade mostrava um ceod de 2 , enquanto que até $75 \%$, um ceod de até 4,5 .

Medeiros et al. (1998) avaliaram 726 bebês (ambos os sexos) de 6 a 36 meses de diversas cidades do estado do Rio de Janeiro e verificaram, através de um questionário direcionado aos pais, que $37,42 \%$ destes bebês consumiam muito açúcar e que a prevalência de cárie aumentou com a idade dos bebês, sendo de $16,67 \%$ na faixa etária de 6 a 36 meses. Utilizando o ceod modificado, incluindo as lesões de mancha branca e também as lesões com cavitadades, verificaram que aos 6 meses, as crianças apresentaram ceod=0, e aos 12 meses, ceod=3. Já aos 36 meses, das 16 crianças examinadas, 9 já apresentavam dentes cariados, com um total de 31 dentes com cárie. Os autores verificaram que a prevalência de cárie 
avaliada pelo ceod modificado, foi de $1,56 \%$ entre os 6 aos $12 \mathrm{~m}$; de $13,45 \%$ entre os 13 aos $24 \mathrm{~m}$; e de $35 \%$ entre os 25 aos $36 \mathrm{~m}$.

Martins, Araújo e Veloso (1999), avaliaram 72 prontuários de crianças entre 3 e 9 anos, de uma clínica extra muro da Faculdade de Odontologia da UFMG, que atendia população de baixa renda na região metropolitana de Belo Horizonte. Os autores verificaram que a renda familiar de $70,6 \%$ da população era de até 2 salários mínimos e que apenas 2 crianças com dentição decídua (2/38; 5,26\%) estavam livres de cárie. Das crianças entre 6 e 9 anos, 63,5\% tinham lesões de cárie exclusivamente em decíduos, enquanto que 36,6\% já apresentavam lesões em permanentes. A variável sexo não foi considerado. De acordo com os autores, não houve interesse dos pais para promoção e manutenção da saúde bucal de seus filhos, já que $63,15 \%$ das crianças com dentição decídua (3 a 5 anos) apresentavam dentes com comprometimento pulpar.

Na cidade de Paulínia, estado de São Paulo, no ano 2000, foi realizado um levantamento sobre a prevalência da cárie dentária, em um total de 1.151 pessoas. Destas, 192 crianças tinham entre 5 e 6 anos. Nas crianças de 5 anos, o ceod foi de 1,90 e nas de 6 anos, de 2,40, indicando um aumento da prevalência da cárie com o aumento da idade. A porcentagem de crianças sem experiência de cárie (ceod $=0$ ) aos 5 anos foi de $54,2 \%$ e aos 6 anos, foi de $41,7 \%$. (GOMES at al., 2004).

Bonecker et al. (2000), realizaram estudos nos anos de 1995 e de 1997, no dia da Campanha Nacional de Multivacinação em Diadema, SP, município que possui água fluoretada. Os autores avaliaram respectivamente 548 e 590 crianças (ambos os sexos) de baixo nível sócio-econômico, nas faixas etárias de 5 a 35 meses, nestes 2 anos. Quando analisaram as mesmas faixas etárias, verificaram que houve uma redução estatisticamente significante $(p<0,002)$ nas porcentagens de crianças com experiência de cárie, entre os dois anos de $45 \%$ para $28,6 \%$. Esta porcentagem foi significante $(p<0,001)$, quando se considerou lesões incipientes, constatando que, as crianças do segundo estudo estavam muito menos acometidas por cárie incipiente, em relação ao primeiro estudo, com o ceos na faixa etária entre 24 e 36 meses (de uma média de ceos =2, no ano de 1995, para ceod = 1,1, em 1997), sem a inclusão de cárie incipiente, ele continuou 5 vezes maior que na faixa etária entre 12 e 24 meses (redução de 0,2 nessa faixa, equivalente a 50\% 
de redução). Além disso, houve um aumento no número de crianças de 2 anos com menor quantidade de superfícies dentárias acometidas por cárie, pois 82,2\% das crianças de 2 anos, no ano de 1995 apresentaram no máximo, ceos=3, comparativamente a 90,8\% das crianças, no ano de 1997. Quanto à distribuição das lesões de cárie no ano de 1997, houve significativo acometimento da superfície oclusal a partir dos 24 meses de idade. Os dentes mais acometidos por cárie foram os incisivos centrais superiores, na faixa etária abaixo dos 36 meses.

Ao avaliarem a prevalência de cárie em 674 crianças de 0 a 6 anos em duas cidades do triângulo mineiro (Araguari e Uberlândia), Carvalho et al. (2002) observaram uma maior prevalência de cárie nas crianças da cidade de Araguari (ceod=3,2), que não possui água de abastecimento fluoretada, em relação às crianças da cidade de Uberlândia (ceod=1,7), que possui água fluoretada. Além disso, para ambas as cidades, houve maior prevalência de cárie nas escolas públicas (Uberlândia: $n=176$, ceod=1,93 e Araguari: $n=177$, ceod=3,8) em relação às particulares (Uberlândia: $n=158$, ceod=1,47 e Araguari: $n=163$, ceod=2,6).

Hoffmann et al. (2004) avaliaram 888 escolares de 5 a 12 anos da rede pública e particular do município de Rio Claro, estado de São Paulo, que possui água de abastecimento fluoretada. De acordo com os autores, aos 5 anos de idade, o ceod foi de 2,48, aumentado proporcionalmente até a idade de 8 anos. Quando se calculou o ceod excluindo as crianças livres de cárie ou considerando-se somente aquelas com o ceod>3, não se verificou diferença significante entre elas, quanto ao nível sócio-econômico.

Bönecker (2005) observou que, em 1.132 crianças de ambos os sexos, a experiência de cárie em molares decíduos mostra um quadro que merece atenção especial dos programas de prevenção, pois foram encontrados valores de ceos=2,3 aos 3 anos e ceos= 3,2 aos 4 anos. Observaram também que, quanto maior o salário da mãe, menor a quantidade de filhos que ela possui e/ou quanto maior seu grau de escolaridade, menor a severidade de cárie na criança. Em relação ao pai quanto maior sua idade, maior sua jornada de trabalho e/ou maior salário, também menor será a severidade da cárie dentária na criança. 
Oliveira et al. (2008), ao avaliarem 691 crianças (348 masculinos, 50,36\% e 343 femininos, 49,64\%), entre 12 e 72 meses, freqüentadoras de creches municipais do município de Bauru, que apresenta água fluoretada, realizaram uma comparação entre os índices ceos e ceos modificado (incluindo lesões de mancha branca) e verificaram diferença significativa entre eles. Enquanto a média do ceos foi de 1,56, a do ceos modificado foi de 1,79. Os autores recomendam o uso do índice ceos modificado, por sua maior sensibilidade. De acordo com os autores, houve diferença estatisticamente significante entre todos os grupos etários avaliados, em relação ao ceos $(p<0,05)$. Já em relação ao ceos modificado, apenas não houve diferença estatisticamente significante $(p=0,92)$ entre os grupos de 49 a 60 meses e de 61 a 72 meses. A porcentagem de superfícies acometidas por cárie em ambos os índices aumentaram com o aumento da faixa etária de 12 a 24 meses $(52,72 \%)$ e 61 a 71 meses $(86,50 \%)$.

\subsubsection{5 - Estudos Isolados no Brasil - Região Sul}

Na região Sul, na cidade de Itajaí, SC (com água fluoretada), Serratine et al. (2003), avaliaram a prevalência de cárie em crianças entre 19 a 31 meses de idade, de 10 creches públicas $(n=236)$ e 4 particulares $(n=91)$ através de exames bucais, utilizando o índice ceo-d. As crianças de escolas públicas examinadas $(n=67)$ apresentaram mais lesões de cárie que as crianças de escola particular $(n=27)$, e em período mais precoce; porém, sem diferença estatisticamente significante. A prevalência de cárie foi de $16,4 \%$ nas escolas públicas e de $14,8 \%$, nas particulares. Em relação ao ceod, foi $=0$, nas escolas particulares, e ceod=0,19, nas públicas, para crianças menores de 23 meses. Já nas crianças entre 23 e 26 meses, ceod=0 e ceod=0,31, respectivamente para escolas particulares e públicas, e ceod=0,25 (escola particular) e ceod=0,5 (escola pública), para crianças maiores de 26 meses de idade. Outro fato também observado foi que a manifestação da doença intensificou-se de acordo com o aumento da idade das crianças.

Em Cascavel, PR, que possui água de abastecimento fluoretada, Davidoff et al. (2005), em um estudo transversal, avaliaram 351 crianças (ambos os sexos) de 
famílias com baixa renda (até 3 salários mínimos) e verificaram que a prevalência de cárie para faixa de 0 a 12 meses foi nula (ceod=0); de 12,3\% para a faixa de 13 a 24 meses (ceod=0,70) e de 34,8\% para a faixa de 15 a 36 meses (ceod=1,16). Já o índice ceod modificado (com inclusão de mancha branca), na faixa de 0 a 12 meses foi de 0,04 ; na faixa de 13 a 24 meses $(1,01)$ e na faixa de 15 a 36 meses, foi de 2,58. O índice médio do ceod foi de 0,7 e do ceos foi de 1,16. Os índices ceos e ceos modificado foram, respectivamente, na faixa de 0 a 12 meses, iguais a 0 e 0,04; na faixa de 13 a 24 meses, iguais a 0,66 e 1,34; e na faixa de 25 a 36 meses, iguais a 2,4 (ceos) e 3,61 (modificado). Sem considerar a faixa etária, foi verificado pelos autores que as lesões de cárie foram mais prevalentes nos dentes anterosuperiores. A ocorrência de cárie (lesão cavitada) foi polarizada, ou seja, houve concentração da doença e das necessidades de tratamento em uma pequena parcela da população. Apenas $17,67 \%$ das crianças examinadas apresentaram experiência de cárie.

Em Curitiba PR, cidade com água de abastecimento fluoretada, (foi a $1^{a}$ capital brasileira a receber $F$ na água e a 4ํㅗㄹ cidade brasileira, em 1958), Barbosa et al. (2007) verificaram a prevalência de cárie em 1.157 crianças (51,80\% masculinos e 48,2\% feminino) de 5 anos de idade, freqüentadoras de escolas particulares $(20,1 \%)$ e públicas $(78,4 \%)$. Os autores verificaram a prevalência de $51,3 \%$ de crianças livres de cárie. Além disso, foi observada maior prevalência de cárie nas crianças de escolas públicas (52,9\%). O índice ceod médio foi de 2,07, com maior freqüência do componente cariado $(63,2 \%)$, seguido do componente restaurado $(35,2 \%)$. Os dentes mais atingidos foram os segundos molares inferiores decíduos e os menos atingidos foram os incisivos laterais inferiores decíduos.

Na cidade de Canela, RS, onde a água de abastecimento é fluoretada, Kramer et al. (2008) realizaram um estudo transversal em 1.092 crianças (551 masculinos, (50,5\% e 541 femininos, $49,5 \%$ ) de 0 a 5 anos, durante a Campanha Nacional de Multivacinação, realizada no ano de 2003, examinando 1092 crianças para verificar a utilização de serviços odontológicos e a idade da primeira consulta em pré-escolares Os autores verificaram que 13,3\% destas crianças já haviam consultado um cirurgião-dentista, e a grande maioria delas teve a primeira consulta entre os 2 e 3 anos de idade. Observaram também que, quanto maior a idade, maior a freqüência de crianças que já havia consultado o dentista. 
Foram avaliadas 237 crianças de 5 a 11 anos, das escolas de rede rural de ensino de Campo Largo e região Metropolitana de Curitiba. Vicente et al (2008), relacionou incidência de cárie com concentração de bactérias na saliva. Observouse que $73 \%$ das crianças apresentaram alta prevalência de cárie, das quais $87 \%$ apresentaram alta concentração de S.mutans na saliva. Houve uma significância entre a detecção do risco e a manifestação clínica da doença $(p<0,001)$.

\subsubsection{Estudos isolados Internacionais}

Levertt et al (1993), desenvolveu e aperfeiçoou um modelo de avaliação de risco de aparecimento de cárie dentária em crianças. No primeiro estudo, um conjunto de bioquímica clínica, microbiológica e variáveis sóicio-demográficas foi identificado que distinguiu, com um nível aceitável de sensibilidade e especificidade entre crianças que não tinham experiência de anterior de cárie. Um total de 313 crianças de idade de 12-15 anos, 140 de uma comunidade fluoretada e 173 não fluoretada, exames clínicos de CPOS, fluorose dental e placas foram realizados. Um questionário foi utilizado para coleta de dados demográficos com informações de hábitos alimentares, práticas de higiene oral. Em 77,6\% da comunidade fluoretada , houve $79,3 \%$ indivíduos com cárie e em $86,1 \%$ da comunidade não fluoretada, houve $88,1 \%$ indivíduos com cárie.

O’Sullivan e Tinanoff (1993a) verificaram que a prevalência de cárie na região anterior de 369 crianças entre 3 e 4 anos foi de 16\%, sendo que a superfície mesial dos incisivos centrais foi a superfície mais severamente atacada pela cárie, naquelas que apresentaram cárie anterior, (superfície mesial do 51 com 47,4\% de cárie e superfície mesial do 61 com 46,2\% de cárie). A superfície distal dos incisivos centrais foi o segundo local mais afetado pela cárie. Nas crianças com cárie na região anterior e posterior, o ceos médio foi de 14,4, e só cárie anterior o ceos foi de 4,0 e cárie só posterior o ceos foi de 2,9. De acordo com os autores, das crianças com cárie na região anterior da maxila, 87\% destas também apresentaram cárie na região posterior, sugerindo que a cárie anterior contribui para o aumento do risco de cárie em outros dentes. 
O'Sullivan e Tinanoff (1993b), em outro estudo longitudinal, examinaram 217 crianças americanas de 5 anos de idade, do estado de Connecticut, cuja água de abastecimento é fluoretada. Após 1 ano 59,9\% apresentaram cárie e a prevalência de cárie na região maxilar anterior foi de 17,5\%, em relação à amostra total, e de 29,2\% entre as crianças com cárie. Destas últimas, apenas 3,1\% apresentaram cárie apenas na região anterior, sendo que $70,8 \%$ apresentaram cárie apenas na região posterior, e 26,1\% das crianças apresentaram cárie em ambas as regiões. O ceos médio das crianças que apresentavam cárie concomitante na região anterior e posterior foi de 18,97 ( $\mathrm{DP}=14,4)$, e só cárie posterior foi de 3,71 ( $\mathrm{DP}=3,61)$ enquanto que, nas crianças que apresentaram apenas cáries posteriores na primeira avaliação, foi de 3,71 (DP=3,61) e anterior e posterior foi de 9,24 (DP=9,49). Das crianças que apresentaram cárie anterior $86,8 \%$ tinham cáries de fossa e fissura, $39,5 \%$ proximal posterior e $28,9 \%$ cárie lingual.

Reisine, Litt e Tinanoff (1994), avaliaram 460 crianças americanas de baixa renda entre 3 e 4 anos, em um estudo longitudinal. No primeiro ano do estudo, verificaram que $40 \%$ apresentaram cárie ativa, e a média do ceos foi de 2,5. Já no segundo ano, avaliaram 210 crianças e constataram que a prevalência de cárie aumentou de $40 \%$ para $58 \%$ e o ceos de 2,5 para 4,5 .

O’Sullivan e Tinanoff (1996), em um estudo longituinal sobre a prevalência de cárie, na cidade de Hartford, Connecticut, cidade com água fluoretada, após avaliarem anualmente 142 crianças, com média de idade de 3,8 anos, por dois anos, verificaram que as crianças que apresentaram lesões de cárie na região anterior apresentaram ceod sete vezes superior e as que apresentaram lesões de cárie de cicatrículas e fissuras na primeira avaliação apresentaram ceod 4 vezes superior após 2 anos, em relação às crianças livres de cárie, quando da primeira avaliação. Após 2 anos, crianças que apresentaram, na primeira avaliação cárie de cicatrícula e fissura apresentaram incremento 1,5 x maior de cárie de cicatrícula e fissura, quando comparado com criança que era livre de cárie na primeira avaliação, com diferença estatisticamente significativa. Criança com cárie na região anterior da maxila na primeira avaliação, tinha 2,4 x incremento de lesão de cárie de cicatrícula e fissura, comparado ao grupo livre de cárie, com diferença estatisticamente significante. Além disso, crianças com cárie na região anterior da maxila na primeira avaliação, apresentaram lesão de cárie na superfície vestibular/lingual com 
incremento de $8 \times$ em relação às livres de cárie. Nesta primeira avaliação, 59\% das crianças estavam livres de cárie (ceod=0), já na segunda avaliação, apenas 39\% destas estavam livres de cárie.

Slade et al. (1996) avaliaram crianças entre 5 e 15 anos em dois estados da Austrália, que possuíam flúor na água de abastecimento, em um estudo longitudinal, utilizando o CPOD e ceos. Foi avaliada a dentição decídua de 9.690 crianças entre 5 e 10 anos, sendo que a percentagem de crianças de 5 anos na amostra foi de $73,5 \%$. O ceos médio, nessa idade foi de 2,28, e na idade de 6 anos, foi de 2,61. Aos 5 anos, 39\% das crianças apresentaram ceos $>0$ e aos 6 anos, essa percentagem foi de $42 \%$. A experiência de cárie foi distribuída predominantemente nas superfícies de cicatrículas e fissuras e superfícies mésio-distais. Aos 5 anos, 3/4 das superfícies com experiência de cárie encontravam-se nos molares decíduos.

Bolin et al. (1997), através de um estudo multicêntrico, a partir dos dados de um programa sobre saúde bucal infantil, que envolvia oito países europeus, avaliaram 3.200 crianças de 5 e 12 anos de idade, entre os anos de 1993/1994. Os autores observaram 200 crianças de cada faixa etária em cada cidade participante. (200 de 5 anos e 200 de 12 anos). Na faixa etária de 5 anos, o ceos médio encontrado foi de 2,8 quando ambos os pais possuíam alto nível socioeconômico (status ocupacional) e de 7,1 quando ambos os pais possuem baixo status ocupacional. As crianças de Scottish, com idade de 5 anos e baixa renda o ceod foi de 2,0 e p=0,001, em relação aos outros países.

Holst et al. (1997) avaliaram 102 crianças suecas, do condado de Blekinge, até a idade de 4 anos em um estudo longitudinal, para avaliar os fatores de risco da cárie e verificaram que a percentagem de crianças sem manifestação de cárie aos 4 anos foi de $92,9 \%$ e ceod $=0$.

Em 2001, Lulic-Dukic et al. avaliaram 145 crianças croatas (77 masculinos e 68 femininos), da cidade de Zagreb, de uma creche, com idades entre 2 e 5 anos, através de exame clínico bucal para se verificar a prevalência de cárie e avaliar seu risco. O estudo foi retrospectivo e utilizado o índice ceos modificado. Verificou-se que 30\% destas apresentaram cárie precoce da infância. As meninas foram menos afetadas (25\%) que os meninos (48\%). Os valores de ceos encontrados foram de 
8,6 nas crianças com CPI e de 5,2, no grupo controle, sem CPI ( $p<0,05)$. Os autores utilizaram como critério para classificar as crianças com CPI a presença de no mínimo 2 dos 4 incisivos superiores com lesões de cárie em superfície lisas, considerando a presença de mancha branca e cavitação.

Hallet e O’Rourke (2002) realizaram um estudo seccional cruzado em 3.375 crianças australianas entre 4 e 6 anos de idade, na região norte de Brisbane, região que não possuía água fluoretada. Constatou-se que 62,4\% das crianças eram livres de cárie, o ceod médio da amostra total foi de 1,54 e a média do ceos foi de 2,51. Foi estatisticamente significante para a presença de ECC a etnia ceod=1,37; classe social=1,47; idioma ceod=1,35; mamadeira adocicada ceod=2,90; mama dormindo ceod=1,49; mama de dia $\operatorname{ceod}=1,35$.

Ao realizarem um estudo prospectivo de cáries em 698 crianças no estado do lowa, que apresenta fluoretação da água, Warren et al. (2002), examinaram crianças de nível econômico mais alto, entre 4 anos e meio e 5 anos e, observaram que a prevalência de cárie foi baixa, com $73 \%$ sem nenhuma experiência de cárie. Quando presentes, as lesões não cavitadas foram mais prevalentes que as cavitadas. $56 \%$ das lesões foram localizadas em fossas e fissuras de molares e $58 \%$ em superfícies lisas.

Wennhall et al. (2005), em um estudo longitudinal, avaliaram 804 crianças (407 masculinos e 397 femininos) moradoras de uma área multicultural e sócioeconomicamente baixa da Suécia, sendo que a maioria (94\%) era imigrante. A quantidade de fluoreto na água de abastecimento era de 0,22 ppm. Inicialmente, foi realizado um programa de intervenção com a primeira avaliação aos 24 meses de idade, depois aos 27, 30, 33 e 36 meses. Neste programa, os pais foram instruídos quanto à escovação, além de fornecimento de tabletes com flúor gratuitamente e recomendações de dieta. Aos 2 e 3 anos de idade, foram realizados exames clínicos bucais. Os resultados foram comparados com um grupo de referência, de crianças com 3 anos de idade $(n=217)$, onde não foi realizada nenhuma intervenção. Os resultados obtidos revelaram que o número de crianças livres de cárie após 1 ano de intervenção foi de 37\% comparado com 15\% do grupo de referência, sendo estaticamente significante $(p<0,001)$. A presença de mancha branca foi verificada em $52 \%$ no grupo em que houve intervenção, e de $45 \%$, no grupo de referência, 
sem diferença significativa. Já a presença de lesão cavitada foi de $29 \%$ no grupo em que houve a intervenção e de $55 \%$ no grupo de referência, com diferença estatisticamente significante $(p<0,001)$. A presença de cárie para a idade de 3 anos foi pouco significante para o grupo de intervenção comparado com o grupo de referência, $\operatorname{ceod}=3,0$ e ceod $=4,4$, respectivamente.

Para Leroy et al. (2005), após avaliação de 4.468 crianças, a formação da cavidade de cárie em molar permanente foi claramente influenciada pelo estado dos molares decíduos adjacentes, principalmente segundo molar decíduo. Se ambos os molares decíduos têm experiência de cárie, e a criança apresenta pobre higiene bucal (acúmulo de placa na superfície oclusal de primeiro molar permanente), ocorre um pico de susceptibilidade à cárie de 1 a 2 anos após a erupção do primeiro molar permanente.

Brodeur e Galarneau (2006), ao avaliarem 2.512 crianças canadenses, da cidade de Quebéc com idade entre 5-6 e 7-8 anos, constataram alta prevalência de cárie em $24 \%$ das crianças, com ceos médio de 14,9, nas crianças com alto risco de cárie. Os dentes mais afetados foram os 4 segundos molares $(21 \%)$ e os primeiros molares inferiores (24\%). Foi verificado que 42\% das crianças com 5 e 6 anos já apresentavam $\mathrm{CPI}$, com ceos médio de $3,9.58 \%$ das crianças apresentaram ceos $=0 ; 18 \%$ das crianças apresentaram uma média de ceos de 2,3.

Adekoya-Sofowora (2006), em um estudo transversal, mediu a prevalência e padrão de distribuição da cárie de 423 crianças (225 masculinos e 198 femininos) no subúrbio da Nigéria de 3 a 6 anos de idade, sem flúor na água de abastecimento, sendo o flúor presente no creme dental fluoretado usado para limpeza dos dentes. A prevalência de cárie foi de $10 \%$ e uma média de dentes cariados, perdidos e obturados (CPOD) foi de 0,3 com o D - componente que compreendeu a $92 \%$. O CPOD de crianças com alto estatuto social foi maior do que crianças com baixo estatuto social. Das 46\% das crianças com diagnóstico de cárie 29 (63\%), apresentaram cárie nos dentes posteriores, 3 (6,5\%), cárie somente nos dentes anteriores e 14 (30,4\%), ambos anteriores e dentes posteriores afetados. 89,1\% crianças livres de cárie (ceod=0), uma possível polarização. A importância da educação odontológica e medidas tanto curativas como preventivas são importantes para esta população. 
Robke (2007) realizou um estudo epidemiológico para fornecer dados representativos sobre a saúde bucal de crianças pré-escolares no noroeste da Alemanha. Foram examinadas clinicamente a prevalência de cárie, e a proporção de cárie na primeira infância (ECC) devido a prática do uso da mamadeira, a freqüência e extensão das más oclusões na dentição decídua de 434 crianças com idade de 2 a 6 anos. Destas, 61\% eram livres de cárie e 25\% não apresentaram má oclusão. Lesões inicias de cárie em bebês foram observados quase que exclusivamente sobre os incisivos superiores e o apinhamento primário foi a má oclusão dominante $(36,9 \%)$.

Em Beijing, China, Qin et al. (2008), ao avaliarem 246 crianças menores que 4 anos, em um estudo transversal, encontraram 117 com mais de 5 dentes cariados, portadoras de cárie precoce severa da infância e 129 crianças livres de cárie, denominadas grupo controle. As crianças de 24 meses com cárie precoce da infância e apresentaram ceod de 9,2 e ceos de 15,5. As crianças entre 24 e 35 meses, apresentaram ceos $=9,3$ e ceod de 15,6. E, aquelas entre os 36 e 48 meses, apresentaram o ceos de 9,2 e o ceod de 15,5, e, avaliaram através de um questionário hábitos alimentares e prática de higiene oral.

Luca, Munteanu, Farcasiu (2008), realizou um estudo retrospectivo em 673 crianças (369 meninos e 304 meninas) com idade menor que 71 meses examinados no Departamento de Odontologia Pediátrica Carol Davila University. Nos estudos anteriores de 2001-2004 apresentou um índice de prevalência de cárie severa na primeira infância com IPS-ECC de cerca de $30 \%$ entre crianças que frequentaram o Departamento d Odontologia, comparado com IPS-ECC=24,81 (2005-2006). A proporção de crianças com idades de 3 anos ou na sua primeira visita foi de $73 \%$ (2005-2006), comparado com 56,14 (2001), 61,63 (2002), 54,55\% (2003) e 61,67\% (2004). Das 673 crianças examinadas 76 (11,29\%) estavam livres de cárie e 597 (88,71\%) tiveram cárie em dentes decíduos 430 (63,89\%) teve em comum padrão de cárie, $167(24,81 \%)$ teve graves cárie precoce severa e para o grupo de estudo inteiro foi de 24,81\%: 430 Embora a prevalência de S-ECC mostra uma queda, e ainda permanece elevada e o aumento do percentual de crianças que procuram tratamento aos 3 anos ou menos indica consiciência dos pais sobre o assunto. 


\subsection{PLACA VISÍVEL}

Alaluusua, Malmivirta (1994), avaliou um total de 92 crianças (53 masculinos e 53 femininos) e suas mães em um estudo em período de 1 1/2 período de ano. A idade das crianças no início do estudo foi de 19 meses. As variáveis estudadas foram placa bacteriana visível na superfície vestibular de incisivos superiores, o uso da mamadeira, a prevalência de cárie da mãe e o seu nível salivar de estreptococos mutans. A placa visível e o uso da mamadeira foram associados com o desenvolvimento de cárie, enquanto as outras duas variáveis apresentaram fracas ou nenhuma associação estatisticamente significativa. $O$ melhor indicador foi o de placa visível, sua sensibilidade foi de $83 \%$ e especificidade de $92 \%$, e valor de prognóstico positivo de 63\%, enquanto para o negativo de 97\%. Globalmente, 91\% das crianças foram corretamente classificadas com esta variável, enquanto as porcentagens correspondentes a outras variáveis variaram de 72 a 77 . Os resultados sugeriram que a placa visível nas superfícies vestibulares de incisivos de uma criança é um sinal de risco de cárie.

Mattos-Graner et al (1998), associou prevalência de cárie (presença de placa visível nas superfícies vestibulares dos incisivos superiores), microbiológicos (níveis salivares de estreptococos mutans) e variáveis da dieta, foi avaliada em 142 crianças (ambos os sexos) de idade de 1 a 2,5 anos, na cidade de Piracicaba SP. Foi significante para prevalência de cárie entre crianças com e sem placa visível $12,08 \%, p<0,001$. A média das superfícies cariados foi significantemente maior em crianças com placa visível nos incisivos superiores do que em crianças sem ela $(p<0,001)$. O grupo mutans foi detectado em $114(80,3 \%)$ das crianças e a prevalência de cárie mais elevada foi significativa para as crianças com altos níveis de mutans em relação as com nível baixo $(p<0,001)$. A prevalência de cárie foi significantemente nas crianças que foram amamentadas até aos 3 meses do que aquelas amamentadas por mais tempo $(p<0,05)$, nas que mamavam na mamadeira com sacarose ou cereais $(p<0.05)$, e nas que começaram comer pratos salgados $(P<0,01)$. Há uma associação entre a prevalência de cárie em crianças jovens e os níveis de estreptococos de grupo mutans, fatores clínicos e dietéticos. 
O controle da placa bacteriana continua sendo o método mais eficaz para a diminuição da atividade cariogênica, associada ao uso diário de fluoretos e ao controle da dieta alimentar. (MEDEIROS et al., 1998).

Galgut, (1999), em seu estudo comparou índices na avaliação de placa e gengiva, os que quantificam (através de escores 0-3, 0-5, várias regiões em cada superfície do dente), uma variável e os que determinam a presença ou a ausência de uma variável (binário). O primeiro é altamente efetivo, mas são mais sensíveis e requer um tempo maior para administrá-lo, enquanto que o segundo, é fácil e rápido de administrar, pois não quantificam variáveis clínicas apensas anota a presença ou ausência como um ou zero. Ambos os tipos de índices são indicadores bons das variáveis clínicas.

Segundo Tinanoff, Kanellis e Vargas (2002), a presença de placa visível pode ser um preditor acurado do risco de cárie em crianças muito jovens.

Pienihakkinen, Jokela e Alanen (2004) avaliaram 226 crianças finlandesas de 2 anos de idade que foram acompanhadas por um período de 3 anos. Aos 2 anos, a presença de placa visível foi registrada quando encontrada na superfície dentária vestibular. Se pelo menos um dente fosse afetado, todo o sextante era considerado positivo. De acordo com os autores, a presença de placa na superfície vestibular dentária tinha baixo valor preditivo de risco de cárie, e não foi considerado fator indicador de risco de cárie. Foram obtidos valores similares na primeira e na segunda avaliação, sem diferença significativa. A maioria (85\%) das crianças, na primeira avaliação, não apresentou nenhum sextante com placa.

Leite et al. (2004), ao avaliarem 45 crianças entre 5 e 6 anos de idade, de duas creches mineiras, da cidade de Belo Horizonte, através de um estudo trasnversal, observaram sangramento gengival, principalmente na região dos molares em decorrência de uma má escovação e falta do uso do fio dental em áreas de contato justo, o que favorece o acúmulo de placa, em mais da metade das crianças. A presença de placa visível foi bastante alta nas crianças das duas creches $(68,4 \%$ e $84,6 \%)$ e a instituição com maior índice de placa apresentava também um maior índice de cárie, mostrando a relação entre a placa visível e cárie dentária. Ainda, houve presença de sangramento gengival, após o uso de fio dental, 
em $51,1 \%$ das crianças examinadas, principalmente na região dos primeiros e segundos molares decíduos. O IPV foi calculado em todas as crianças considerando o acúmulo de placa apenas na superfície vestibular de todos os incisivos superiores.

Ao acompanharem 33 crianças gaúchas da cidade de Porto Alegre, de 3 a 6 anos, em um estudo transversal, Santos et al. (2004) verificaram que todas as que pertenciam aos grupos mais críticos referentes à cárie e doença periodontal, ingeriam sacarose em alta freqüência, mais de 3 vezes ao dia (16 crianças). O IPV utilizado nesta pesquisa foi o IPV modificado e simplificado, que considera todas as faces vestibular e palatina/lingual de todos os decíduos presentes na arcada. O IPV destas crianças foi 0 em 2 delas ( $40 \%$ da amostra de 5 crianças com esse IPV); de 1 a $50 \%$ em 6 crianças ( $75 \%$ das crianças, em um total de 8 ) e IPV de 51 e 100\% em 8 crianças (100\% das crianças), quanto à freqüência de ingestão de sacarose 3 vezes ou mais ao dia.

Couto et al. (2005), ao examinarem 260 crianças pernambucanas da cidade de Camaragipe, entre 0 e 36 meses, observaram que a maioria delas entre 1 e 18 meses $(86,5 \%, n=109)$ apresentaram IPV baixo. Foi considerado baixo quando apresentou valores até 33,33\%, médio de 33,4\% até 66,66\% e alto entre 66,67 até 100\%. Entre as crianças de 19 a 36 meses, 44,8\% (60 crianças) apresentaram IPV baixo (até 33,33\%); 16,4\% (22 crianças) apresentaram IPV médio (considerado de 33,34\% a 66,66\%); e 38,8\% (52 crianças) apresentaram IPV alto (acima de $66,67 \%)$. O IPV considerou a presença e a ausência de placa dental visível e foram analisadas as superfícies vestibulares dos incisivos superiores.

Scavuzzi et al. (2007), em um estudo longitudinal prospectivo, com 186 crianças baianas, de Feira de Santana, que possui água fluoretada, com idades entre 12 e 30 meses, após observação de placa em incisivos superiores, verificaram que o ceos foi menor nos casos em que a criança não apresentava placa visível. Houve um aumento significante no ceos entre as crianças com e sem esta condição na primeira avaliação. O ceos foi menor entre as crianças sem placa visível na primeira avaliação. Nas crianças que possuíam mancha branca na primeira avaliação, este aumento foi maior quando a criança apresentava placa visível em relação a que não apresentava, sendo esta diferença estatisticamente significante $(p<0,01)$. 
Declerk et al (2009), examinou a prevalência e severidade de cárie na dentição decídua de crianças pré-escolares e avaliou a associação da doença com o nível de higiene, comportamentos de saúde bucal e fatores sócio-demográficos de 1250 crianças com idade de 3 anos e 1283 com idade de 5 anos na cidade de Flandes. Em relação à idade de 3 anos, 7\% apresentaram experiência de cárie e $31 \%$ placa visível, enquanto $31 \%$ aos 5 anos e $37 \%$ de placa visível.

212 crianças de 6 a 24 meses (51\% masculino e 49\% feminino), participaram de um estudo nos Estados Unidos na comunidade rural de lowa. Warren et al (2009), avaliou os exames odontológicos utilizando D1, (não cavitado), D2-3 (cavitado), fatores de risco, todos coletado no início e após 9 e 18 meses. Cerca de 128 crianças permaneceram no estudo após 18 meses. Entre estas crianças a prevalência D1 aumentou de 9 para 77\% e D2-3 de 2 para 20\%. Para D2-3 foi encontrada presença de mutans (OR=4,4, IC95\%: 1,4, 13,9) e bebidas açucaradas (OR=3,04, IC95\%: 1,1, 8,6), sendo que estes foram significativos e são preditores da ECC, em populações de alto risco.

\subsection{SANGRAMENTO GENGIVAL}

A presença da doença periodontal na infância nem sempre tem sido motivo de preocupação por parte dos profissionais que lidam com crianças. A negligência profissional se reflete na crença de que crianças não possuem alterações periodontais com conseqüências graves e, principalmente, que a dentição decídua não necessita de tratamento. Entretanto, a importância da detecção precoce, da prevenção e do tratamento da doença periodontal, cuja precursora é a gengivite, ainda na fase de dentição decídua, resultará numa população adulta mais saudável do ponto de vista da saúde bucal. (SCAVUZZI et al., 2001).

Cangussu et al. (2001), em um estudo transversal, verificaram boa condição periodontal em 109 crianças (ambos os sexos) de 5 anos de idade, da cidade de Itatiba, SP, que apresenta água fluoretada, com presença de periodonto saudável em $79,1 \%$ dos sextantes avaliados, com presença de sangramento em apenas 
19,9\% dos sextantes. Os autores utilizaram o Índice Comunitário Periodontal. que permite avaliar a condição periodontal quanto à higidez, sangramento, e presença de cálculo e bolsa.

Silveira, Oliveira e Padilha (2002), em um estudo realizado em 42 crianças de 4 a 13 anos de idade, com idade média de 9 anos, com 4 dentes afetados pela doença cárie, em média, através de um programa de integração DocênciaAssistência da Secretaria Municipal dde Saúde do Rio de janeiro, com alunois do nono período de Graduação de Odontologia da Universidade Estácio de Sá, RJ. Foi utilizado o ISG- inicial e ISG-final. O ISG inicial (antes de receber qualquer informação ou orientação prática no escovódromo sobre escovação e uso de fio dental) na primeira avaliação foi de 13\%, e após intervenção (ciclo de atividades promocionais de saúde como palestras e orientação de escovação), o ISG final foi reduzido para $5 \%$. A superfície oclusal e incisal não foi incluída pro não apresentar relação com o sulco gengival.

O Índice de Sangramento Gengival é um sinal facilmente detectável de alteração gengival aceito pela maioria dos profissionais. Por ser simples, nãosusceptível à interpretação subjetiva e requerer um pequeno tempo de exame, é largamente utilizado em levantamentos de grupos populacionais. Esse índice deve ser utilizado para registrar as alterações gengivais em crianças de 5 anos de idade. Quando for observado, após o exame, qualquer sinal de sangramento, será indicado a sua presença. Se, durante esse exame, não for observado tal sinal, será registrada ausência de sangramento. (PEREIRA, 2003).

A expressão "doença periodontal" representa um grupo de patologias que afeta os tecidos periodontais como as gengivites e periodontites, sendo a gengivite a doença bucal de maior prevalência. É encontrada em todas as idades, desde que a placa se acumule por um certo período de tempo. A variação que ocorre entre indivíduos é decorrente de diferentes respostas do hospedeiro. (SANTOS et al., 2004).

Estudo longitudinal de 3 anos realizado na Finlândia, por Pienihakkinen, Jokela e Alanen (2004) com 226 crianças, iniciou a primeira avaliação quando elas tinham 2 anos. Aos 2 anos, a presença de sangramento gengival foi registrada 
quando encontrada na superfície vestibular dentária. Se pelo menos um dente fosse afetado, todo o sextante era considerado positivo. O número respectivo de sextante foi calculado para superfície plana (máximo 6), para anterior (máximo 2) e posterior (máximo 4) na dentição. A maioria das crianças (98\%) não apresentou nenhum sextante com sangramento gengival. A presença de sangramento gengival teve baixo valor preditivo para risco de cárie na amostra estudada pelos autores.

Segundo Santos et al. (2004), após um estudo transversal realizado em 33 crianças gaúchas de Porto Alegre, com idade de 3 a 6 anos, como baixa renda e baixo nível de escolaridade dos pais. Com o objetivo de aprofundar o conhecimento da realidade do núcleo familiar das crianças acompanhadas em creches, relacionado à prevalência da doença cárie e doença periodontal com as condições sócio-econômicas do núcleo familiar dos pré-escolares usuários da creche comunitária Centro Infantil Murialdo - CIM.Os autores puderam observar que, das 16 crianças que ingeriam sacarose mais de 3 vezes ao dia, 3 apresentaram ISG=0 (42,9\% de 7 crianças); 11 (91,7\% de um total de 12 crianças) apresentaram ISG de 1 a 50\%; e 2 (100\%) apresentaram ISG entre 51 e 100\%. De um modo geral, 7 crianças apresentaram ISG igual a zero, 12 crianças, ISG entre 1 e $50 \%$ e 2 crianças ISG de 51 a 100\%. O ISG utilizado foi o ISG modificado e simplificado, considerado presente quando, após a sondagem leve na entrada do sulco gengival (com uma sonda periodontal), houvesse qualquer superfície com sinal de sangramento. $100 \%$ das crianças co 6 ou mais dentes cariados eram cuidados pro indivíduos de baixa escolaridade ( primeiro grau incompleto ou analfabeto).

Após avaliarem 804 crianças com 2 e 3 anos idade, na Suécia, de baixo nível econômico, Wennhall et al. (2005) verificaram que 39,1\% das crianças as quais os autores intervieram com programas de higiene, apresentaram sangramento gengival, comparadas com 49,3\% das crianças sem intervenção $(p<0,01)$. O índice utilizado foi com sangramento e sem sangramento após esvovação.

Santos e Soviero (2008), apresentaram uma revisão de literatura sobre os métodos de avaliação da higiene bucal em lactentes e pré-escolares através do registro de biofilme dental e condição gengival. Vários índices foram propostos para registrar o acúmulo de biofilme dental e diferentes metodologias foram empregadas na tentativa de se obter índices de fácil e rápida execução (uso do corante, apenas 
o registro do biofilme visível, presença de biofilme em todos os dentes, presença ou ausência do biofilme). Em relação à condição gengival também, muitos são os índices utilizados (inflamação ausente, leve, moderada ou severa; presença ou ausência de sangramento; uso da sonda periodontal no fundo do sulco gengival e uso do fio dental nas faces proximais de todos os dentes decíduos). É importante que os índices sejam práticos, rápidos e facilmente reprodutíveis.

Pigozzo et al (2008), em um trabalho de revisão de literatura fala dos principais índices utilizados para mensurar saúde bucal. Dentre eles, os índices utilizados em levantamentos epidemiológicos para detectar a presença de doenças nos tecidos periodontais que também verificam a freqüência ideal de controle clínico periodontal, os índices de placa para avaliação da higiene bucal e os índices utilizados para mensurar prevalência de cárie, tais como o índice de CPO-D, universalmente aceito para avaliar o risco de cárie. Observou-se que estes índices detectam a presença e a severidade das doenças, permitindo que políticas públicas sejam aplicadas com foco de objetividade, para solucionar os problemas de saúde apontados, mas dependem essencialmente do julgamento clínico do examinador, podendo, assim, serem influenciados por fatores subjetivos. Há ainda muitas controvérsias a respeito dos principais índices.

Em 2009, Moura et al, selecionou 341 pacientes, divididos em 2 grupos comparativos. O primeiro (experimental) com 262 crianças de 3 a 6 anos e que freqüentaram o Programa Preventivo para Gestantes e Bebês, o outro (controle), com 79 crianças de 3 a 6 anos e que não freqüentaram o Programa, mas eram atendidas por médicos e outros profissionais de saúde no Instituto de Perinatologia social do Piauí. O ISG foi realizado com uma sonda periodontal específica, posicionada a $60^{\circ}$ em relação ao eixo do dente, que percorreu a margem gengival a uma profundidade média de $1 \mathrm{~mm}$. O exame foi iniciado sempre no dente 55, continuando uma seqüência até o 85. A sondagem foi realizada nas superfícies vestibular e lingual de todos os dentes decíduos em três pontos distintos: central, mesial e distal de ambas as superfícies, totalizando 40920 pontos examinados. A presença ou ausência de sangramento foi avaliada. Aos 3 anos a média do ISG foi de $2,7 \%(n=35)$, comparada com a idade de 6 anos 3,79 $(n=4)$. Das $74 \%$ do grupo experimental e $82,3 \%$ do grupo controle apresentaram sangramento gengival em algum sítio avaliado. As crianças que apresentaram menores ISG 11 (13,7\%) foram 
as que freqüentaram com maior assiduidade as consultas de manuntenção preventiva do Programa Preventivo para gestante e Bebês.

Ao avaliar 230 crianças de idade de 6 anos de idade, em Reykjavik, na Islândia, Arnlaugsson et al (2009), observou a prevalência de gengivite e constatou que $26 \%$ das crianças tinham gengiva saudável, $23 \%$ sangramento em uma superfície, $20 \%$ a partir de duas, $17 \%$ entre três e $15 \%$ de quatro a oito. O ISG foi utilizado para avaliar a gengiva na vestibular de superfícies vestibulares de seis dentes $(55 / 54,52 / 53,64 / 65,84 / 85,72 / 73,75 / 74)$. A sonda periodontal foi inserida com leve pressão no sulco de duas ou três vezes em cada lugar, quando a hemorragia observada em 10 segundos a resposta era positiva ao sangramento. Houve diferença estatisticamente significante para os dentes 84/85 (42\%) em relação ao $72 / 73(29 \%)$.

\subsection{FATORES DE RISCO E INDICADORES DE RISCO PARA A CÁRIE DENTÁRIA EM PRÉ-ESCOLARES}

Burt (2001) define risco como a probabilidade de um evento ocorrer. Relata que os termos relacionados, como fator de risco, fator de riscos modificáveis, fator de risco demográficos, indicadores de risco determinados muitas vezes não são bem definidos pela literatura. Um fator de risco deve estar associado a um resultado. Pode ser um fator ambiental, comportamental ou biológico. É a ênfase temporal de exposição antes do resultado, é parte da cadeia causal, é a aceitação de fatores de risco que são envolvidos no início da doença, não necessariamente na sua progressão futura ou resolução.

A avaliação do risco de cárie é a ação de predizer se determinado paciente desenvolverá lesões durante um determinado período de tempo. O risco está na dependência de uma interação por determinado tempo, entre os conhecidos fatores etiológicos da cárie dentária, ou seja, a exposição à microbiota cariogênica, dieta contendo sacarose consumida frequentemente e hospedeiro susceptível. (ARAl et 
al., 2003). Bem como a uma gama de fatores ambientais e genéticos que envolvem o paciente no seu relacionamento familiar e social.

Para classificar cada paciente quanto ao seu risco de cárie, podem ser usados o diagnóstico clínico, as indicações de lesões de cárie passadas recentes e a presença de fatores de risco modificáveis. O risco de cárie é, portanto, a probabilidade de desenvolver novas lesões ou a progressão das já existentes dentro de um período variável. (TREATING, 1995).

Reisine, Litt e Tinanoff (1994), ao acompanharem 210 crianças australianas de 3 e 4 anos de idade por um ano, observaram que aquelas que apresentaram maior ceos $(2,8,40 \%)$, maior contagem de $S$. mutans na saliva (1-50, 45\%), e aquelas que os pais relataram maior freqüência de escovação (27\%), apresentaram mais lesões de cárie no segundo ano de avaliação (ceos=4.5, 58\%). Para os autores, os preditores da cárie mais importantes foram o ceos no ano anterior e nível salivar de de S. mutans. E, $28 \%$ faziam uso de mamadeira ao dia, $32 \%$ uso à noite, a população era de baixa renda.

Shou e Uitenbroek (1995) investigaram a influência do fator sócio-econômico na saúde bucal de 520 crianças escocesas de 5 anos de idade. Os autores concluíram que o comportamento materno (tabagismo, escovação e visitas ao dentista) influenciaram na experiência de cárie de seus filhos, pois a proporção de crianças que apresentaram ceod=0 foi de: $75 \%$ daquelas cujas mães não fumavam; $70,8 \%$ daquelas cujas mães visitavam o dentista regularmente e 73,2\% daquelas cujas mães escovavam seus dentes 2x/dia. O fator sócio-econômico (avaliado por tempo de estudo e ocupação da mãe, além da ocupação do parceiro), independente do indicador usado, foi estatisticamente relacionado com a experiência de cárie. Quanto mais baixo o nível socioeconômico, maior probabilidade de cárie (ceod>1). Além disso, quanto menor o nível sócio-econômico, maior o consumo de açúcar por estas crianças.

Bolin et al. (1997), através de um estudo multicêntrico, a partir dos dados de um programa sobre saúde bucal infantil, que envolvia oito países europeus, avaliaram 3200 crianças entre 5 e 12 anos de idade, entre os anos de 1993/1994. Os autores observaram 200 crianças de cada faixa etária em cada cidade 
participante. Os indicadores de risco de cárie avaliados, através de questionários, foram classe social da família, tabagismo materno e número de irmãos das crianças de 5 anos. Foi verificado que nas crianças de baixo nível social, havia maior necessidade de tratamento, com maior índice ceod. Estas diferenças entre as crianças de diferentes classes sociais foram mais evidentes na amostra de 5 anos. De acordo com os autores, na maioria das amostras (exceção de um país), as crianças de classe social mais alta apresentaram menores médias dos índices ceos/CPOS em relação às crianças de classe social mais baixa. Quando a atividade (o status) ocupacional do pai ou da mãe era considerados baixos, os valores dos índices ceos/CPOS era maiores nas crianças, principalmente aos 5 anos.

Holst et al. (1997) avaliaram o risco de cárie de 102 crianças suecas, do condado de Blekinge, até a idade de 4 anos, em um estudo longitudinal, verificaram que os fatores de risco mais freqüentes encontrados aos 2 anos de idade foram a falta de higiene bucal e presença de fissuras profundas nos primeiros molares associada à placa visível, ingestão freqüente de bebidas açucaradas associada à placa visível.

Walter e Nakama (1998), a partir de uma população de 2.191 crianças (223 masculinos, 54,10\% e 189 femininios, 45,9\%), de 0 a 24 meses, avaliaram 412 que apresentavam ausência de cárie, e que foram acompanhadas longitudinalmente. A partir da determinação do risco de cárie, baseado em fatores ambientais como higiene bucal, hábitos alimentares (consumo excessivo de carboidratos com freqüência maior que 6x/dia e, amamentação noturna), após acompanhamento por 1 ou 2 anos, os autores constataram que, no início do acompanhamento, 320 das 412 crianças $(77,7 \%)$ foram consideradas de risco e $92(22,3 \%)$ sem risco. Ao final do acompanhamento, apenas 54 crianças das 412 do total da amostra $(13,1 \%)$ apresentaram risco e $358(86,9 \%)$ das crianças foram consideradas sem risco, revertendo o quadro de risco, posto que, das 320 crianças que apresentaram risco no início, 266 (83,1\%) reverteram o risco ao longo do acompanhamento. A idade ideal da criança para entrar em um programa de prevenção é a de 12 meses, sendo que a educação prévia dos pais é um dos fatores mais importantes para manutenção da saúde bucal. 
Em 2001, Lulic-Dukic et al. avaliaram 145 crianças croatas (77 masculinos e 68 femininos), de uma creche, com idades entre 2 e 5 anos, através de exame clínico bucal. De acordo com os autores, a utilização da mamadeira não representou um risco de cárie significante, mas quando adocicada, ingerida à noite, e quanto ao hábito de escovação nos primeiros 24 meses pela própria criança foi significante $(p<0,00)$ para ECC.

Hallet e O’Rourke (2002), após avaliarem 3.375 crianças australianas através de um estudo longitudinal, entre 4 e 6 anos de idade, em uma região da Austrália sem fluoretação da água, verificaram, que a amamentação natural, durante a noite estava significativamente associada com menor experiência de cárie precoce da infância. Porém, as chances da ocorrência da cárie precoce da infância aumentaram significativamente se as crianças eram amamentadas no peito, durante a noite além dos 24 meses de idade. Dos 19\% das crianças examinadas que não utilizavam mamadeira, 30,5\% desenvolveram cárie precoce da infância, comparadas com $39,3 \%$ das crianças que utilizavam exclusivamente a mamadeira. Para os autores, os fatores determinantes para o estabelecimento da cárie precoce na infância são: líquidos açucarados na mamadeira, amamentação natural após os 24 meses, introdução de alimentos sólidos após os 9 meses, uso noturno da mamadeira e adormecimento, uso da mamadeira durante o dia, uso da mamadeira além dos 12 meses e uso da amamentação no peito além dos 24 meses. Sendo significantes: socioeconômico (OR=1,93, $\mathrm{Cl}=1,47,2,52)$, uso noturno da mamadeira $(\mathrm{OR}=1,73$, $\mathrm{Cl}=1,49,2,52)$, uso da mamadeira dia $(\mathrm{OR}=1,58, \mathrm{Cl}=1,35,1,84)$.

Segundo Tinanoff, Kanellis e Vargas (2002), em um trabalho de revisão da literatura, verificaram que os indicadores de risco de cárie são: experiência prévia de cárie, presença de mancha branca ou defeitos do esmalte, placa visível e nível sócio-econômico da família. As estratégias de prevenção da cárie em crianças préescolares incluem modificações da dieta com redução da freqüência de consumo de açúcar, escovação dentária supervisionada, suplementos de flúor para crianças de risco que vive em regiões onde a água não é fluoretada, aplicação tópica de fluoretos por profissional, e utilização de selantes nos primeiros molares permanentes. 
Hallet e O'Rourke (2003), após realizarem um estudo seccional cruzado de 2 515 crianças australianas de 4 e 5 anos, constataram que a prevalência $(44,8 \%)$ e severidade(ceod=2,05) de cárie precoce da infância foi estatisticamente maior quando associada ao hábito da utilização da mamadeira noturna. A prevalência de cárie aos 4 anos de idade foi de 30,7\%(ceod=1,29), enquanto que, aos 5 anos de idade, foi de $34,9 \%(\operatorname{ceod}=1,45)$. O uso diário de refresco e refrigerante aumenta significativamente a severidade da CPI $(p=0,001)$. A introdução de alimentos sólidos entre 4 e 6 meses de idade reduziu significativamente a prevalência e severidade da CPI $(p=0,001)$ quando comparada com o início mais tardio ou mais precoce que 4 a 6 meses $O$ nível sócio-econômico é um fator de risco independente importante, pois o baixo nível sócio-econômico estava relacionado ao aumento da cárie precoce da infância. A prevalência da cárie dentária nas crianças que começaram a escovar os dentes aos 12 meses foi de 31,6\%, enquanto que a prevalência nas que iniciaram a escovação aos 13 meses, foi de 38\%. Estudaram também variáveis como mama no peito entre 3 a 6 meses ceod=0,5, dorme com a mamadeira ceod=1,5, beberica a mamadeira $\operatorname{ceod}=1,4$, etnia $\operatorname{ceod}=1,4$, renda anual familiar $\operatorname{ceod}=1,3$.

Diversos fatores devem ser considerados na avaliação do risco de cárie, entre eles pode-se citar alguns como: a história de cárie do indivíduo, a quantidade de placa bacteriana presente nas superfícies dentárias, 0 tipo de bactérias presentes, a freqüência de ingestão de carboidratos fermentáveis, a secreção salivar, a capacidade-tampão da saliva e a presença de fluoretos._(ARAl et al., 2003).

Na região Sul, na cidade de Itajaí, SC (com água fluoretada), Serratine et al. (2003), verificaram através de questionários, o grau de instrução e renda dos pais, para tentar estabelecer uma relação entre esses parâmetros de 236 crianças de 10 creches públicas e 4 particulares com 91 crianças. Os autores constataram que o grau de instrução e a renda familiar das crianças das escolas particulares foram maiores que o das provenientes de escola pública, sendo esta diferença estatisticamente significante $(p<0,01)$. Porém, este grau de instrução não teve relação com a prevalência de cárie nas crianças_estudadas.

Em um estudo transversal, Steclsen-Blicks, Suinnegardh e Borssen (2004), realizados em 1967, 1971, 1976, 1980, 1987, 1992, 1997 e 2002, em 182 crianças 
de 4 anos em Umeda, uma cidade no norte da Suécia, realizou exames de cárie e fatores de risco, tais como hábitos de higiene bucal, uso do flúor e consumo de açúcar. Os mesmos métodos e critérios foram utilizados em cada estudos 19672002. O número de crianças com cárie diminuiu de $87 \%$ em 1967 para $42 \%$ em 1987, e o declínio estabilizou. Em 2002 46\% das crianças que tinham cárie o valor médio do CPOS foi de 2,0 e 6\% das crianças tinham CPOS igual ou maior que 10. Houve diferença significante para freqüência de escovação $(p<0,01)$. Embora os produtos açucarados entre as refeições aumentaram entre 1987 e 1997, não foram notadas mudanças de 1997-2002 e não houve mudanças importantes na prevalência de cárie durante os últimos 15 anos.

Kiwanuka, Astrom, Trovik, (2004), avaliou o impacto sócio demográfico e comportamentos correlatos da experiência de cárie e os padrões de consumo de açúcar entre as crianças pré-escolares de Uganda. 589 crianças de idade de 3,4,5 anos, que freqüentavam creches em áreas urbanas e peri-urbanas em Kampala central e Nakawa foram clinicamente examinadas para cárie utilizando o índice CPOD. A placa visível foi registrada nas regiões vestibular de incisivos superiores e um questionário foi aplicado para avaliar as características sócio-demográficas e hábitos de açúcar. A pontuação média do CPOD foi de 1,7, 2,4, 3,1 e 42\%, 44\%, $42 \%$, tinham placa visível entre 3,4,e 5 anos de idade respectivamente. Em Nakawa , um total de 64\%, 62\% e 22\%,tinham CPOD >0, dentes caraiados (dt)>0 e dentes $>0$ respectivamente, comparadas com Kampala central 56\%, 55\%, 17\%. Em Nakawa mãe com menor nível social de educação, relatou ingestão de xarope para tosse e placas foram associadas com probabilidades de CPOD $>0$. Os escores ajustados para freqüência media de açúcar variaram entre mães de baixo e altos níveis de educação (média de 11,0 pontos vs 10,4) e para crianças com escores de placa negativa e positiva (média $=10,6$ vs 10,9). A exepriência de cárie foi maior entre crianças que frequentaram escolas em Nakawa e aquelas que tiveram longos períodos de consumo de xarope para a tosse, tanto a experiência de cárie e frequência de consumo de açúcar foi maior entre crianças de nível de educação baixo da mãe.

Azevedo, Bezerra e Toledo (2005), ao avaliarem 369 crianças (188 masculinos, $51 \%$ e 181 femininos, 49\%),entre 36 e 71 meses, com média etária de 52 meses, observaram a presença de cárie precoce severa da infância em 36\% 
delas. $\mathrm{Na}$ idade de 36 a 48 meses, 30\% das crianças apresentavam cárie; entre 48 e 60 meses, 39\% a apresentavam, e entre 60 a 72 meses, 40\% das crianças foram afetadas. O critério para classificação de CPSI foi 1 ou mais superfície lisa com cavidade restaurada ou dente perdido devido à cárie em dente decíduo anterior superior. Através de um questionário observou-se que a maioria dos pais da amostra possuía baixo nível de escolaridade, educação elementar ou analfabeta (71\% dos pais e $61 \%$ das mães), com baixo nível sócio-econômico. A amamentação no peito durante o período noturno ocorreu em $72 \%$ das crianças e estava estatisticamente associada à presença de cárie precoce na infância $(79 \%$ das crianças). O uso da mamadeira noturna e amamentação no peito em crianças maiores de 12 meses foram relacionados com a presença da cárie precoce da infância.

Petersen (2005), propõe em seu trabalho que fatores sociais se relacionam à cárie. Enfatiza que os riscos para a saúde é a chave para prevenir doenças e que a taxa de fator de risco possa medir o potencial de prevenção. Define risco como uma probabilidade de um resultado adverso, ou um fator que aumenta esta probabilidade. Nenhum risco acontece em isolamento, e muitos têm raízes em cadeias complexas de eventos que medem períodos longos de tempo. Cada evento tem suas causas e pode se ter várias causas. Comportamentos sociais e culturais podem influenciar nos padrões de estilo de vida e assim, nos processos fisiológicos. $\mathrm{Na}$ saúde oral a prática de higiene, hábitos dietéticos, uso do tabaco e consumo excessivo de álcool são relacionados à experiência de cárie. Programas e estratégias de prevenção são importantes para redução de fatores de risco.

Helderman, Soe e Hof (2006), em um estudo retrospectivo de coorte, realizado em Rangum, Myanmar, demonstraram que 198 crianças entre 25 e 30 meses, que apresentavam cárie precoce da infância também apresentavam alguns hábitos considerados de risco à cárie, como o consumo de alimentos açucarados; de arroz pré-mastigado pelas mães e ainda, adormeciam amamentando no seio. A presença de cárie em pelo menos um dente já foi considerada cárie precoce da infância. De acordo com os autores, a amamentação natural noturna após os 12 meses de idade é um fator de risco para desenvolvimento da cárie precoce da infância. Um tempo mais prolongado de amamentação natural aumenta 
significativamente o risco de desenvolvimento da cárie. A amamentação natural durante o dia e após a idade de 12 meses não foi associado à cárie.

Crianças canadenses, entre 5-6 anos e 7-8 anos foram avaliados, por Brodeur; Galarneau, em 2006, através de um estudo longitudinal, e foi constatado que as que possuíam alto risco de cárie, apresentaram ceos=14,9. Destas crianças, $11,7 \%$ apresentaram 3 ou mais superfícies dentárias necessitando de tratamento. De acordo com os autores, os dentes mais afetados foram os quatro segundos molares, com incidência de $21 \%$, e os primeiros molares inferiores, com incidência de $24 \%$, seguido pelos segundos molares superiores (15\%) e incisivos superiores (4 a 8\%). Os incisivos inferiores e os caninos foram pouco afetados. Considerando-se o ceos modificado, havia 96 superfícies envolvidas. Destas, a porcentagem de lesões de cárie em superfície lisa foi de 54,3\% em cicatrículas e fissuras foi de $45,7 \%$, na superfície oclusal foi de $39,4 \%$ e em outras superfícies (6,3\%) na fissura vestibular em molares inferiores, e fissura palatina de molares superiores. Quando se considerou o ceos modificado foram encontradas 96 superfícies com cárie. Os autores salientaram que crianças com alta incidência de cárie e aquelas que necessitavam de tratamento para cáries extensas, provinham de classes sociais mais baixas, e que a atividade de cárie na dentição decídua iniciava-se em idade precoce, além de se desenvolver rapidamente.

Galarneau et al. (2006) realizaram um estudo transversal com 776 mães de crianças canadenses com idades entre 15 e 18 meses, através de um questionário contendo 36 perguntas. $29 \%$ das mães expunham seus filhos à cárie através de mamadeira com leite, no período noturno. Comidas doces são fornecidas às crianças por $16 \%$ das mães. De acordo com os autores, a pobreza tende a levar ao aumento do uso de comidas adocicadas. Uma em cada três mães de baixo nível sócio-econômico expõe seus filhos a comidas altamente cariogênicas com o intuito de os fazerem adormecer, comparado a uma em cada seis mães com melhores condições econômicas.

Maliderou, Reeves e Noble (2006), investigaram o efeito socieconômico, o açúcar e o consumo de lanches sobre a prevalência e severidade da cárie. Observaram um total de 60 crianças (26 masculinos e 34 femininas) de 5 a 16 anos de idade, na área do Chelsea, Londres. As crianças foram mistas de grupos étnicos 
e socioeconômicos. Os grupos sociais I e II que consumiram açúcar, batata frita e doces foram significantemente menor $(p<0,05)$ que os demais grupos. As crianças dos grupos sociais I,II,III apresentaram CPO mais baixos, sendo o CPO médio social das crianças do grupo I foi de 0,5 + 0,6, em relação ao grupo IV de 4,6 + 0,8, correlações significativas. $92 \%$ das crianças que tinham CPO $=0$ eram filhos de pais que trabalhavam em profissões técnicas ou administrativas, enquanto que pais parcialmente qualificados (80\%), não qualificados (86\%), desempregados (67\%) apresentaram CPO médio superior a $4(p<0,05)$. A situação sócio-econômica teve efeito significativo sobre a ingestão de açúcar, escolha de alimentos e saúde bucal.

Em um estudo realizado com 278 mães de bebês de 0 a 3 anos de idade matriculadas em creches públicas da cidade de Bauru-SP, Theodoro et al (2007), através de um questionário, determinou a relação entre o nível socioeconômico e o grau de conhecimento das mães em relação à saúde bucal de seus bebês. Com relação à renda familiar $31,09 \%$ foi de 2 a 3 salários mínimos e a renda inferior a 1 salário mínimo de 13,14\%. Para 95,89\% das mães os dentes do bebê devem ser higienizados após a mamada no peito ou na mamadeira, 93,15\% acreditam que há problema do bebê dormir mamando, a incorporação de açúcar na mamadeira ou alimentação predominou entre 6 e 12 meses (24,65\%), 49,31\% das mães usam o dentífrico fluoretado assim que os primeiros dentes erupccionam, com 71,23\% fazem uso de pequena porção e a primeira visita ao CD, 53,42\% deveria acontecer antes do irrompimento dos primeiros dentes. Houve correlação estatisticamente significantemente entre as duas variáveis estudadas $(p<0,05)$. E, observou-se que quanto maior o nível socioeconômico da mãe, maior seu grau de conhecimento sobre a saúde bucal.

Freire, Nunes e Soares (2007), compararam fatores relacionados à saúde bucal em creches públicas e filantrópicas de Goiânia-GO, com água fluoretada, entre 1993 ( $n=49)$ e 2001 ( $n=41)$, em uma população de 0 a 6 anos de idade, de baixa renda. Os dados foram coletados através de entrevista junto aos responsáveis pelas instituições. Num intervalo de oito anos (1993 a $2001 \mathrm{n}=49$ e $2001 \mathrm{n}=41$, respectivamente), todas as creches contavam com água fluoretada (98\% e 100\%) e escovação com creme dental fluoretado (91,8\% e 100\%). A escovação passou a ser em crianças mais jovens ( $<1$ ano, 0 e $0 \%$ e, 18, 43,9\%, houve aumento na freqüência diária de escovação ( $2,4,4$; para $4,9,8)$ e supervisão de um adulto de 41 
$(91,1 \%)$ para $38(92,71 \%)$, todos comparados com os anos de 1993 a 2001. Não observou-se mudanças em relação à utilização de açúcar nas refeições, nestes anos (100\%, 100\%), a freqüência diária de consumo em 2001 foi alta $(22 \%)$ e, a grande maioria das instituições continua não contando com qualquer assistência à saúde bucal.

Em um estudo transversal, na cidade de lowa, Warren et al (2007), através de um questionário, avaliou fatores associados à cárie em 212 crianças de 6 a 24 meses com idade média de 13 meses. Das 212 criança/pares mães, 187 tinham dentes. A presença de cárie foi significante associada com a idade avançada (34\% para 50 crianças com 18 meses), presença de SM em crianças ( $n=152,38 \%$ ) e renda familiar baixa $(n=148,15 \%)$, proporção de dentes com placa visível ( $n=78$, $30 \%$ ) onde foram registradas para molares superiores/ inferiores e incisivos, uso do flúor ( $n=43,26 \%)$, pasta de dentes $(n=96,15 \%)$, uso do copinho $(n=156,15 \%)$, bebidas açucaradas $(n=23,21 \%)$.

Qin et al. (2008), após realizarem uma avaliação em 246 crianças menores que 4 anos, de Beijing, China constataram que o nível educacional das mães de crianças livres de cárie era mais alto, além de melhor conhecimento sobre higiene bucal, do que o das mães de crianças com cárie precoce severa da infância, com diferenças significativas. Observaram também que a alimentação noturna (amamentação natural e mamadeira) e excessiva ingestão de açúcar foram fatores importantes para o estabelecimento da cárie precoce nestas crianças.

Ao analisar a saúde bucal das 857 crianças de 24-71 meses, atendidas em centros do delta do Mississipi, Shouthward et al (2008), observou que crianças em 19 creches de um segundo estudo, foram examinada pelo dentista, e os pais forneceram dados sobre as práticas de saúde bucal, dentistas também avaliaram placa visível (62,3\%) e testes de SM (49,7\%), história da saúde oral e sobre a saúde oral das crianças como a qualidade de vida. Indicações de cárie no estudo anterior (fio dental e consumo de bebidas açucaradas) foram fatores não indicativos no estudo atual, mas os fatores do segundo todos foram indicadores de cárie e urgente necessidade de tratamento, alguns indicadores como frequência de escovação não foi significante. 
lida et al (2009), associou em um estudo transversal, o aleitamento materno, sua duração, a outros fatores, com risco de cárie precoce em 1576 crianças nos Estados Unidos de 2 a 5 anos de idade. Houve associações com risco aumentado de cárie precoce a idade das crianças mais velhas (5 anos=44,3\%), a pobreza (41,3\%), a visita ao CD (36,3\%) nos últimos 5 anos e tabagismo materno (38,4\%). O aleitamento materno ou a sua duração são fatores de risco independentes para cárie precoce e cárie severa precoce.

A falta de informação dos pais sobre a necessidade de higiene dos dentes que estão irrompendo, e sobre o potencial cariogênico do leite em horários freqüentes, faz com que eles permitam que seus filhos adormeçam durante ou logo após a alimentação (HALLET; O'ROURKE, 2002, 2003). Desta forma, o leite estagnado sobre os dentes, acrescido de uma redução do fluxo salivar durante o sono, proporciona um excelente meio de cultura para microrganismos acidogênicos na cavidade bucal (ABDO et al., 1998). Porém, muitos pais não aceitam a explicação de que a amamentação prolongada seja a causa do aparecimento de cárie, defendendo os benefícios que ela traz; por este motivo, deve-se orientá-los corretamente sobre esse fato, considerando a visita ao dentista após a erupção dos dentes (ABDO et al., 1998; HALLET; O’ROURKE, 2002, 2003).

O uso do cigarro voluntário ou involuntariamente influencia a saúde geral. A fumaça de cigarro do ambiente e o uso de cigarro pela mãe estão associados a um grande número de consequências negativas para a saúde das crianças. (SHENKIN et al., 2004). Cerca de $21 \%$ dos filhos relatam o uso de tabaco se um ou ambos os pais fumam e apenas 9,8 das crianças fumam, quando nenhum dos pais fuma. $O$ modelo paterno parece influenciar o uso experimental e regular de tabaco e álcool dos filhos. O uso pelos pais facilita o acesso dos filhos a essas substâncias. (JACKSON et al., 1997).

A prevalência do uso de cigarro pela mãe está significativamente relacionada com a prevalência de cárie e o seu aumento pela diferença de classe social. A quantidade de cigarros fumada não é importante. Somente o uso de cigarros pela mãe é um fator significante a ser considerado como um indicador de risco adicional além da classe social, quando na predição do risco de cárie em crianças préescolares. Já o vício de fumar do pai versus a ausência do vício não estavam 
relacionados com a classe social da criança. O vício materno de fumar está associado com a experiência de cárie de crianças pré-escolares $(O R=1,54 ; p<0,05)$ mesmo quando ajustada para classe social, "status" nutricional e gasto semanal em doces, enquanto a influência do pai que fuma ou efeito combinado de ambos os pais é menos importante. (WILLIANS et al., 2000).

Aligne et al. (2003), ao analisarem o nível de cotinina de 3.873 crianças entre 4 e 11 anos, verificaram que 53,1\% (n=2.057) destas apresentavam nível de cotinina consistente com exposição à fumaça de cigarro do ambiente, 46,7\% ( $n=1804)$ apresentavam dentes decíduos cariados ou restaurados e 26,2\% ( $n=1015)$ apresentavam dentes permanentes cariados ou restaurados. De acordo com os autores, houve associação significativa entre o nível sérico de cotinina e presença de cárie em dente decíduo. Além disso, baixo nível socioeconômico e de educação do chefe de família também foram significantemente associados ao aumento do risco de dentes cariados e restaurados. Já nos dentes permanentes, não houve associação significativa entre os níveis de cotinina e cárie $(\mathrm{OR}=1,4, \mathrm{Cl}=1,1,1,8)$. De acordo com os autores, um quarto (1/4) das crianças com cárie em decíduos poderiam estar livres desta, se a exposição à fumaça de cigarro do ambiente fosse eliminada.

Shenkin et al. (2004) realizaram um estudo em lowa, EUA em que avaliaram a associação entre o uso do tabaco e cárie dentária na dentição decídua. Eles examinaram 687 crianças entre 4 e 7 anos de idade e, além disso, os pais responderam a um questionário sobre a situação socioeconômica e uso de tabaco. Os autores observaram que as crianças tinham risco aumentado de cárie em lares que havia indivíduos que fumavam. Crianças cujos lares possuíam um consumidor regular de cigarro e apresentaram lesões de cárie mais frequentemente dos que não possuíam ( $44 \%$ e $25 \%$ respectivamente). Após o ajuste de outras variáveis, como idade, fator socioeconômico, freqüência de escovação, ingestão de refrigerantes, a relação entre o uso do cigarro e a cárie ainda permaneceu significante. 
3 Proposição 



\section{PROPOSIÇÃO}

Neste projeto foram avaliadas clinicamente, crianças pré-escolares de instituições públicas, filantrópicas e particulares, moradoras de dois municípios (com e sem atenção odontológica) e com flúor na água de abastecimento, com a finalidade de verificar de forma descritiva e analítica:

- a prevalência de cárie;

- o índice de placa visível;

- o índice de sangramento gengival e,

- fatores indicadores de risco à cárie.

As hipóteses nulas testadas:

1- que não existem diferenças quanto aos indicadores de saúde bucal nas crianças pré-escolares:

- entre os dois municípios;

- entre as instituições públicas e privadas considerando os dois municípios juntos e Areado isoladamente;

- entre as instituições com e sem assistência odontológica considerando os dois municípios juntos e Alfenas isoladamente;

2- que não existe relação entre os fatores indicadores de risco pesquisados e a CPI das populações acima estudadas.

3- o padrão de cárie anterior não exerce influência sobre o padrão de cárie posterior. 



$$
\begin{array}{r}
4 \text { Material e } \\
\text { Métodos }
\end{array}
$$





\section{MATERIAL E MÉTODOS}

O presente estudo foi realizado em dois municípios localizados na região Sul do Estado de Minas Gerais, Brasil. O município de Alfenas a $340 \mathrm{Km}$ da capital do Estado, Belo Horizonte, apresenta uma população estimada de 71.628 habitantes. De acordo com dados fornecidos pela Companhia de Água e Saneamento do Município (COPASA), a água de abastecimento público é fluoretada desde 1971, recebendo um teor de flúor de 0,60 a 0,85 ppm. Areado, o outro município envolvido no estudo, apresenta uma população estimada de 13.203 habitantes, e localiza-se a $385 \mathrm{Km}$ da capital do Estado. De acordo com dados fornecidos pela COPASA a água de abastecimento público é fluoretada desde 1984, recebendo um teor de flúor de 0,60 a 0,85 ppm.

O projeto teve início após a sua aprovação, pelo Comitê de Ética em Pesquisa da Faculdade de Odontologia de Bauru, da Universidade de São Paulo (Anexo 1).

Neste estudo foram realizados exames clínicos bucais em crianças préescolares ( 0 a 71 meses de idade) e foram distribuídos questionários aos pais/responsáveis para a avaliação de fatores indicadores de risco à cárie. A participação das crianças e de seus pais/responsáveis foi condicionada perante a assinatura de um Termo de Consentimento Livre e Esclarecido (Anexo 2).

Ao final do levantamento de saúde bucal foi proferida uma palestra aos pais das crianças envolvidas, abordando os problemas encontrados e os cuidados preventivos necessários para preveni-los. 


\subsection{Seleção da Amostra}

Inicialmente foram distribuídas nas escolas dos dois municípios, as cartas contendo: o convite à participação no estudo; o documento de esclarecimento aos pais/responsáveis e o TCLE (Termo de Consentimento Livre e Esclarecido), além do questionário aos pais/responsáveis. Em Alfenas, existem 07 préescolas/creches públicas e 08 privadas. Em Areado, existem 03 préescolas/creches públicas e 01 privada.

Em Alfenas, foram incluídas as crianças oficialmente matriculadas, nas creches Municipais: Zita Engel (203 crianças), Santos Reis (85 crianças), Santa Luzia (117 crianças), Maria Lúcia Cardoso (105 crianças), São Paulo (25 crianças) e creches Filantrópicas: Centro de Educação Infantil Gota de Leite Mãos Unidas (100 crianças) e Centro de Educação Infantil "Cíntia Maria de Carvalho" (91 crianças) Além delas foram incluídas as instituições da rede particular de ensino: Centro Educacional Mundo Mágico (89 crianças), Centro Educacional Brilho do Saber (70 crianças), Escola Leão de Faria (33 crianças), Colégio Atenas (92 crianças). Na rede privada, das 08 instituições, 04 não aceitaram participar do estudo. Somente as crianças das creches de Alfenas recebem atenção odontológica provida pelas instituições de ensino superior do município.

Em Areado, foram incluídas as crianças oficialmente matriculadas nas três creches municipais: Dona Bita (30 crianças), Casa da Criança (23 crianças), Nova Areado (35 crianças). Além delas foi incluída a única instituição da rede particular de ensino, Escola Infantil Lambuzando e Criando (54 crianças). As crianças das creches de Areado não recebem nenhum tipo de atenção odontológica provida pelo município.

Como critérios de exclusão foram considerados: os pais que não concordaram com a participação de seus filhos neste estudo, a não colaboração das crianças selecionadas da amostra durante o exame, crianças portadoras de doenças sistêmicas, e as que se encontravam ausentes por algum outro motivo no dia do exame. 
Portanto, neste estudo, a amostra total foi de 447 crianças (225 do gênero masculino e 222 do gênero feminino) nos dois municípios juntos. Em Alfenas, as 07 pré-escolas/creches públicas (267 crianças) e 04 privadas (106 crianças) com um total de 373 alunos participantes. Em Areado, as 03 pré-escolas/creches públicas (56 crianças) e 1 privada (18 crianças) com um total de 447 alunos participantes.

\subsection{Condições dos Exames Clínicos}

Os exames foram realizados por um único examinador treinado e calibrado previamente (OMS/99). Além dele, um auxiliar anotou os dados encontrados nas fichas apropriadas.

Para cada um dos exames clínicos a ser realizado foi aceito um índice kappa de concordância maior ou igual a 0,8.

Todas as crianças foram examinadas, em cada instituição, sob condições padronizadas, em ambiente fechado, com luz natural. Durante o exame dependendo de sua idade, a criança ficou sentada em cadeira comum, em pé, ou deitada no colo do operador que realizou o exame na posição de joelho a joelho, com um funcionário da instituição.

As crianças foram examinadas nos períodos da manhã e da tarde, procurando não alterar a rotina da instituição. A seqüência de exames clínicos foi: índice de placa visível (IPV), índice de sangramento gengival (ISG) e, índice de cárie (CPOS e ceos). Todo o material clínico usado para os exames bucais foi previamente esterilizado e o ambiente dos exames foi em local limpo, ventilado com a realização dos trabalhos de forma a cumprir os requisitos necessários de biossegurança. 
4.3 Material usado para a coleta dos dados

\subsubsection{Material de exame clínico}

- espelho bucal plano (Duflex-SS White, Rio de Janeiro, Brasil);

- sonda IPC (Hufrield, Estados Unidos, E.U.A.);

- $\quad$ pinça clínica (Duflex-SS White, Rio de Janeiro, Brasil);

- fio dental não encerado (Sanifil, Curitiba, Brasil).

4.3.2 Material de apoio ao exame clínico

- luva descartável (Satari, São Paulo, Brasil);

- gorro descartável (Embramac, São Paulo, Brasil);

- máscara descartável (Embramac, São Paulo, Brasil);

- sabonete;

- toalha de papel;

- sacos plásticos para descarte de material;

- gaze (Medi House, São Paulo, Brasil);

- espátula de madeira (Estilo, Guarapuava, Brasil)

- álcool 70 p/v (Ciclofarma, Serrana, Brasil);

- caneta esferográfica azul;

- lápis preto;

- borracha;

- fichas clínicas impressas em folhas de papel A4;

- $\mathrm{CD}$;

- Prancheta.

4.3.3 Questionários sobre os fatores indicadores de risco à cárie

Os pais ou responsáveis, além das autorizações permitindo a participação de seus filhos nesta pesquisa, foram instruídos a responder um questionário sem nenhuma interferência do pesquisador, abordando vários aspectos possivelmente relacionados ao risco de cárie da criança (Item 4.7). 


\section{4 Índice de Placa Visível}

Foi empregado o índice de Ainamo; Bay (1975) que avalia a presença ou ausência de placa visível, sem o auxílio de nenhum recurso mecânico ou químico. A ocorrência de placa claramente visível nas superfícies mesial, vestibular e lingual de todos os dentes nos quadrantes direitos de maxila e mandíbula foram examinados. Neste índice a placa a ser considerada, é aquela claramente visível, sem nenhuma dúvida, a qualquer pessoa que esteja examinando. Os resultados foram anotados em fichas apropriadas (Anexo 3). A partir deste capítulo, será empregado o termo biofilme dentário visível.

\section{5 Índice de Sangramento Gengival}

Foi empregado o índice de Carter; Barnes (1974) que avalia, com o auxílio de fio dental não encerado, a presença ou ausência de sangramento gengival e, não a quantificação do grau de sangramento. Este índice foi empregado apenas para as crianças a partir dos 3 anos de idade, por duas razões: a possibilidade de uma maior colaboração, e da dentição decídua estar completa. Todas as superfícies dentárias interproximais foram examinadas, sendo que a boca foi dividida em seis segmentos (Figura 1). 


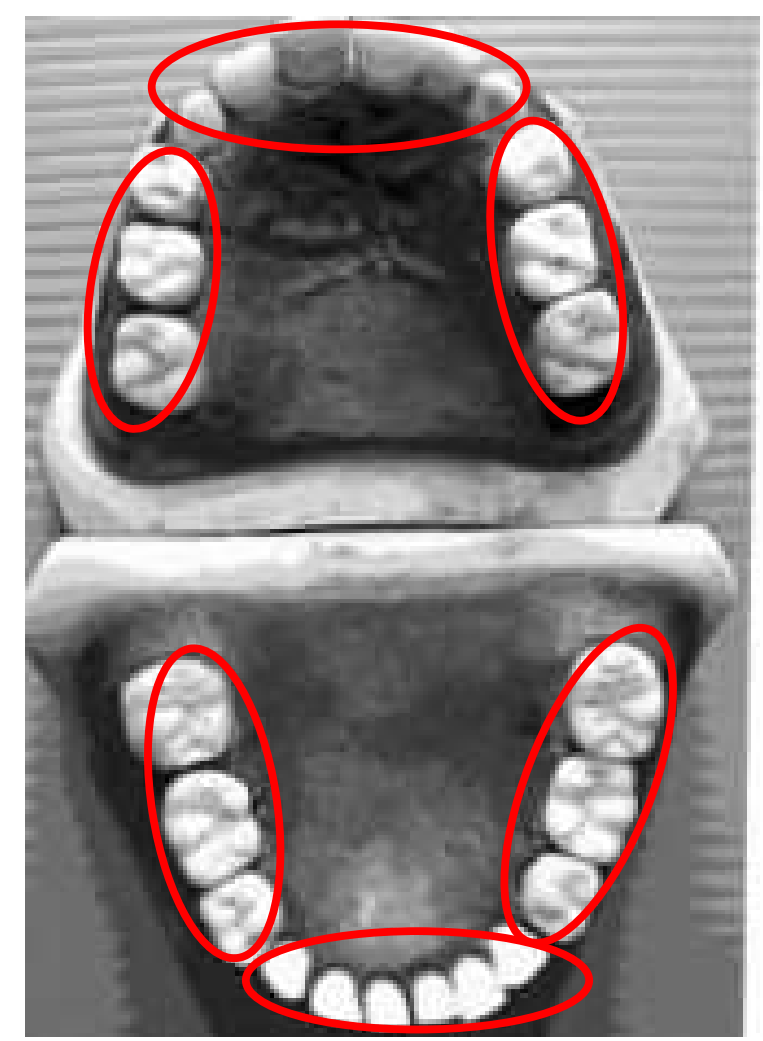

O fio foi passado primeiro nos três seguimentos da Maxila e depois nos três da Mandíbula, respectivamente na seguinte ordem: direito; anterior; esquerdo e, esquerdo; anterior e direito. $\mathrm{O}$ fio foi introduzido no espaço interproximal num movimento inciso-gengival e, passado alternadamente dentro do sulco gengival de cada lado da papila. Neste procedimento teve-se o cuidado para não lacerar a papila. Uma vez ultrapassado o contato proximal, o fio foi estendido tanto quanto possível em direção as face vestibular e lingual e levado para o fundo do sulco. Para cada unidade interproximal, uma nova extensão do fio, foi usada. Durante este exame, houve o afastamento da bochecha do paciente para a aplicação do fio, o que facilitou a visão direta da área, com a finalidade de identificar as unidades e sangramento tanto por vestibular como por lingual. Quando houve sangramento, ele foi imediatamente evidente na área ou no fio. No entanto, permitiu-se cerca de 30 segundos entre um seguimento e um novo, para uma reinspeção da área em exame. Normalmente não ocorre que o sangramento de uma área interfira com outra. Contudo, se houver hemorragia, pode-se lavar a boca do paciente antes da análise do próximo segmento. $O$ operador foi bem treinado, no emprego da pressão digital e no posicionamento do indivíduo durante o exame e adquiriu a habilidade de 
reproduzir o procedimento para os próximos pacientes. O cálculo deste índice é feito anotando-se o total de áreas susceptíveis de risco e o total de áreas que apresentaram sangramento para cada paciente em fichas apropriadas (Anexo 4).

\section{6 Índice de Cárie}

Foram empregados os índices de cárie CPOS e ceos (OMS/99), cujos critérios são descritos no (Anexo 5) e, que avaliaram a presença e a história de cárie do indivíduo por superfície dentária. Os resultados obtidos foram anotados em fichas apropriadas (Anexo 6). O exame foi realizado com um espelho plano e, caso houvesse necessidade, com a finalidade de facilitar o procedimento, o dente pode ser limpo com auxílio da sonda exploradora e de uma gaze seca.

Um foi considerado presente na boca quando qualquer parte dele estava visível. Caso o dente permanente e outro decíduo ocupassem o mesmo espaço dentário, somente a condição do dente permanente foi registrada. Com relação às condições dentárias, tanto letras (dentes decíduos) quanto números (dentes permanentes) foram utilizados para o seu registro. Os mesmos campos foram utilizados, portanto, para registro de dentes decíduos e de dentes permanentes. Um cuidado especial foi tomado para o diagnóstico das restaurações estéticas, que foram de detecção mais difícil.

\subsection{Questionário de Avaliação dos Fatores Indicadores do Risco à Cárie}

O questionário entregue aos pais/responsáveis constava de várias perguntas de múltipla escolha. (Anexo 7). Seu preenchimento foi devidamente explicado, em reuniões na própria instituição que a criança estava matriculada. Os dados colhidos abrangeram aspectos relativos aos fatores indicadores de risco à cárie dentária, associados aos fatores sócio-econômicos familiares, ao grau de instrução dos pais, 
ao tipo de assistência odontológica recebida pela criança, ao tipo de cuidados preventivos caseiros dirigidos à criança e, ao seu padrão dietético.

\subsection{Análise Estatística}

Os resultados do estudo são apresentados com base em um plano de análise quantitativa descritiva mediante a elaboração de tabelas e gráficos ilustrativos dos dados coletados. Para a análise estatística analítica, os índices de saúde bucal: ceos e IPV foi aplicado o teste estatísitco t-Student, e a os fatores indicadores do risco à cárie o teste do qui-quadrado. Para os fatores indicadores com relação significante com a experiência de cárie, foi utilizado o teste Regressão Linear Múltipla. Para todas as análises foi adotado um valor de significância de $\alpha=5 \%$. Os dados foram processados em planilhas do programa Microssoft Exceß ${ }^{\circledR}$ para conferência e posteriores análises. 
5 Resultados 



\section{RESULTADOS}

Os resultados deste trabalho estão apresentados em tabelas e gráficos em virtude do grande volume de informações coletadas, com a finalidade de tornar 0 entendimento mais claro e a apresentação mais objetiva.

\subsection{Análise Descritiva da Amostra Total: Alfenas e Areado}

Foi avaliado neste estudo, um total de 447 crianças entre 0 a 71 meses de idade, de dois municípios do estado de Minas Gerais, sendo 373 (83,5\%) de Alfenas e de 74 (16,5\%) de Areado que pertenciam a instituições públicas 323 $(72,3 \%)$ e privadas $124(27,7 \%)$, Grafico 1.

\section{Criança (n)}

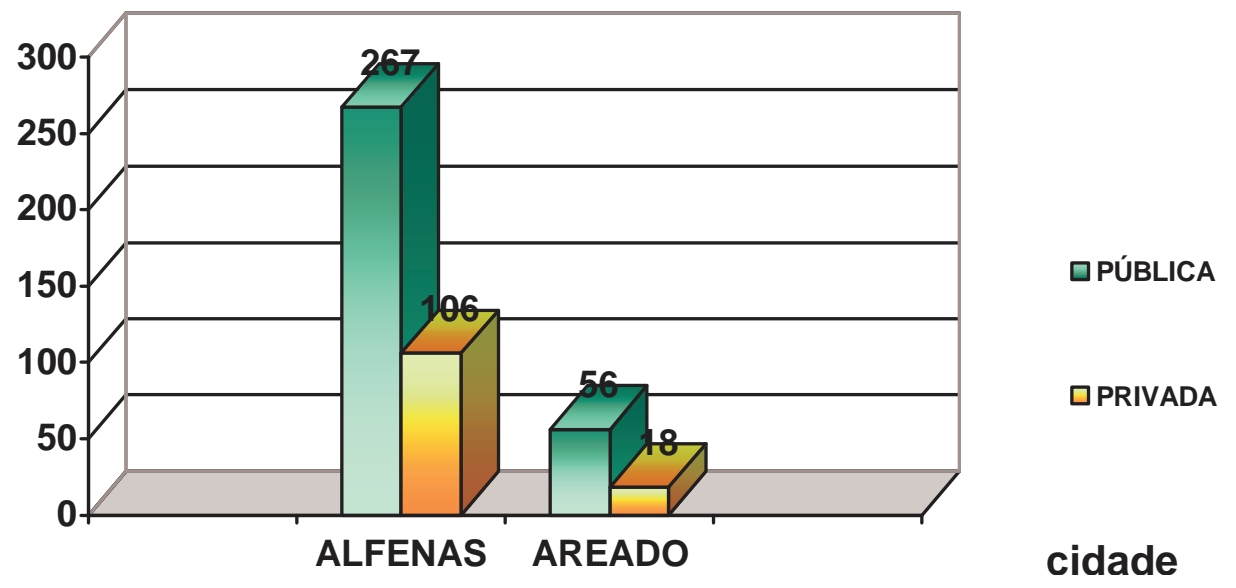

Gráfico 1 - Distribuição de criança por cidade e tipo de escola 
A distribuição das crianças por faixa etária em cada tipo de escola, considerando os dois municípios juntos mostra o predomínio delas em escolas públicas até os 60 meses, e o aumento gradual da presença nas escolas privadas. Chama a atenção que dos 61 aos 71 meses, a presença das crianças nos dois tipos de escola foi bastante equilibrado (Gráfico 2).

\section{Criança (n)}

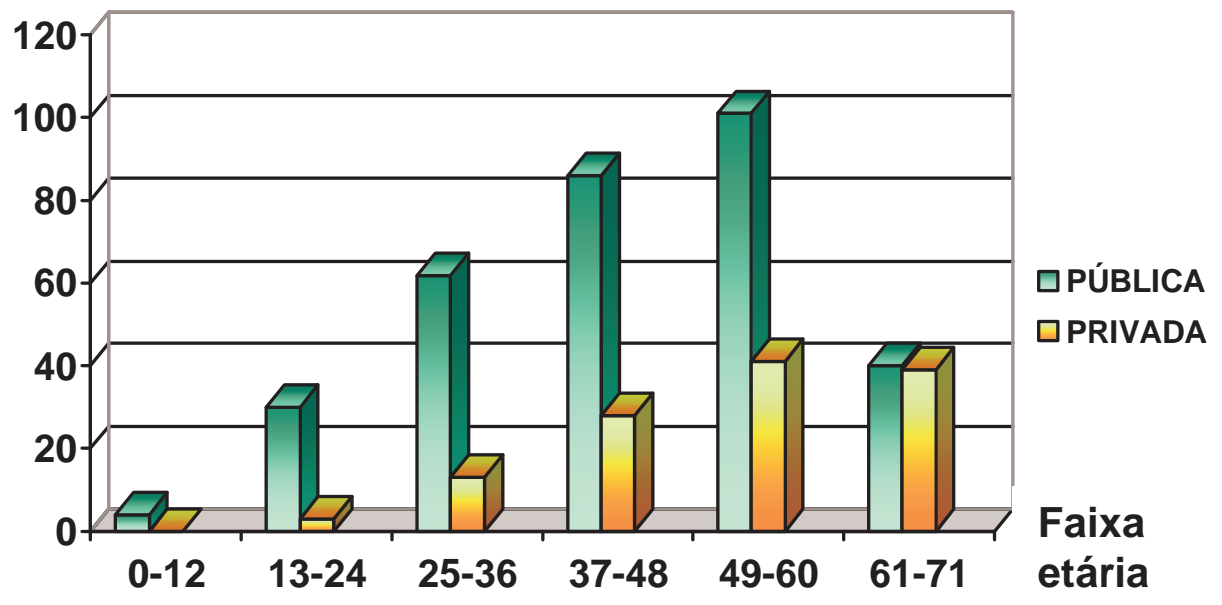

Gráfico 2 - Distribuição de criança por faixa etária e o tipo de instituição

Compuseram a amostra, 222 crianças (49,70\%) do gênero feminino e 225 (50,30\%) do gênero masculino, apresentando uma distribuição homogênea (Gráfico 3).

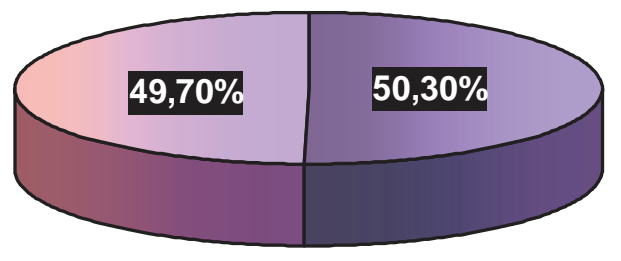

$\square$ MASCULINO

口FEMININO

Gráfico 3 - Distribuição porcentual da amostra segundo o gênero 


\subsection{Análise Descritiva da Amostra Total: Experiência de CPI e IPV}

Observou-se que a maioria das crianças, ou seja, 293 (66 \%) apresentaramse livres de cárie (Gráfico 4), demonstrando a polarização na experiência da CPI na população estudada.

Experiência de CPI

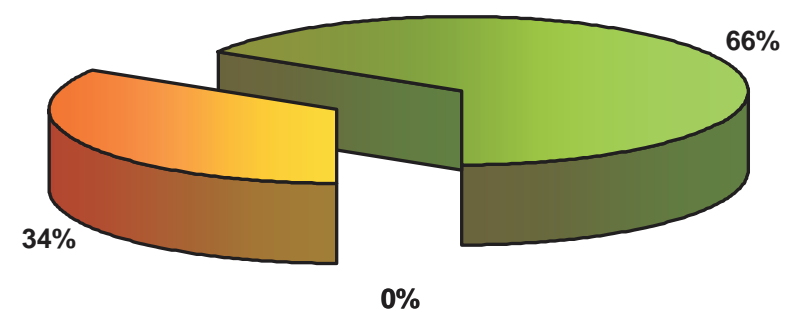

口COM

口SEM

Gráfico 4 - Distribuição de crianças de acordo com a experiência de CPI

Considerando-se a distribuição da experiência de CPI na amostra por faixas etárias, percebe-se que ela se concentra dos 37 aos 60 meses, faixa que abriga o maior número de crianças. Porém dos 37 aos 48 meses a quantidade de crianças com e sem CPI se aproxima, diferindo do que ocorrem nas demais faixas etárias (Tabela 1 e Gráfico 5). 
Tabela 1- Distribuição da amostra total por faixa etária, de acordo quanto à experiência de CPI

\begin{tabular}{c|c|c||c|c||c}
\hline \hline \multicolumn{1}{|c||}{} & \multicolumn{2}{c||}{ ceos $=0$} & \multicolumn{2}{c||}{ ceos $>\mathbf{0}$} & total \\
\cline { 2 - 6 } Faixa Etária & $\mathbf{n}$ & $\%$ & $\mathbf{n}$ & $\mathbf{n}$ \\
\hline $\mathbf{0 - 1 2}$ & 03 & 75 & 01 & 25 & 04 \\
$\mathbf{1 3 - 2 4}$ & 28 & 85 & 05 & 15 & 33 \\
$\mathbf{2 4 - 3 6}$ & 57 & 74 & 20 & 26 & 77 \\
$\mathbf{3 7 - 4 8}$ & 61 & 53 & 53 & 47 & 114 \\
$\mathbf{4 9 - 6 0}$ & 92 & 66 & 48 & 34 & 140 \\
$\mathbf{6 1 - 7 1}$ & 52 & 66 & 27 & 34 & 79 \\
\hline Total & 293 & 66 & 154 & 34 & 447 \\
\hline
\end{tabular}

\section{Criança (n/\%)}

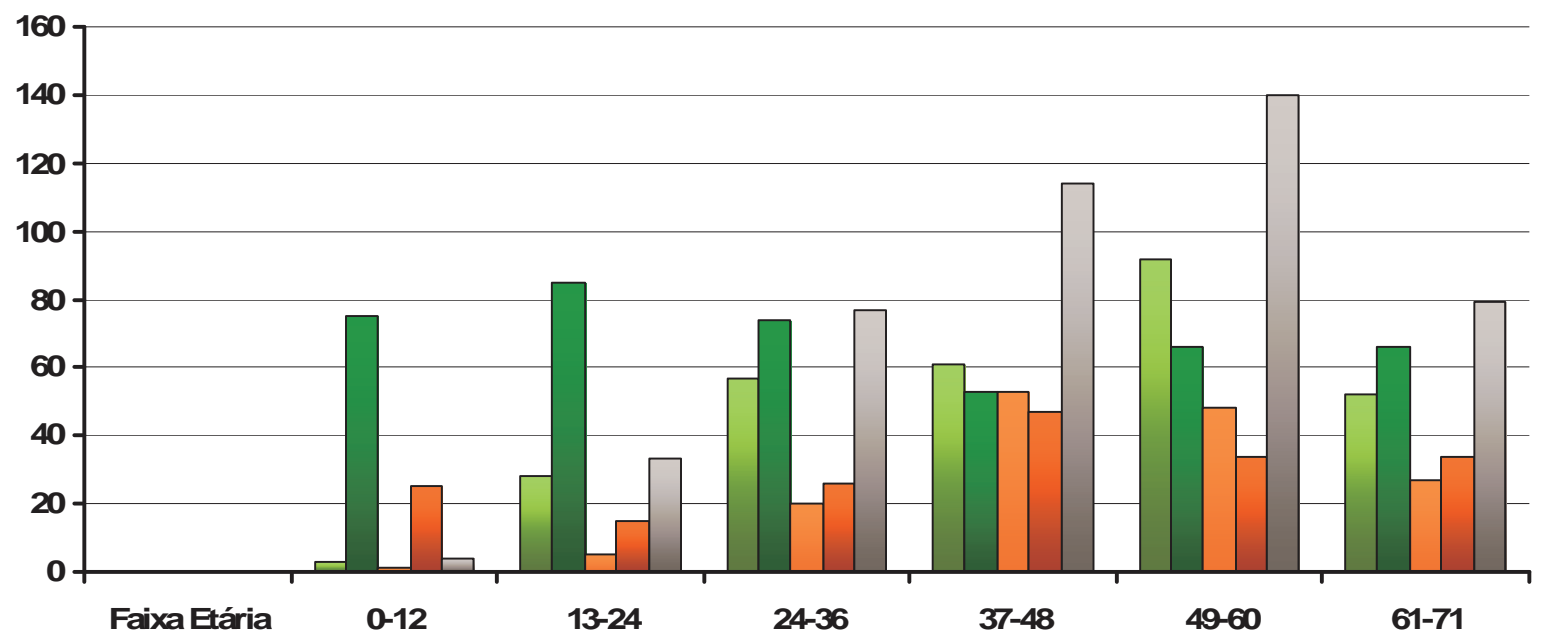

$\operatorname{ceos}=0:$
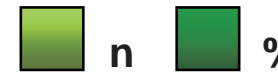

ceos > 0:
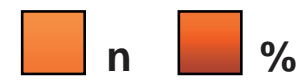

criança (n)

Gráfico 5 - Distribuição da amostra total por faixa etária, quanto experiência de CPI 
Analisando a amostra total, verificou-se que de todas as crianças, 42 ou $9,39 \%$ e 90 , ou $20,13 \%$, eram daquelas com cárie nos primeiros e segundos molares decíduos respectivamente (tabela 2 e gráfico 6). Quando se considera as diferentes faixas etárias, percebe-se que o maior volume de crianças com CPI se concentra entre 37 e 48 meses tanto para o primeiro como para o segundo molar decíduo (gráfico 6) . Além disso, todas as crianças (132) que apresentaram CPI em molares decíduos, a superfície oclusal (119 ou 91\%) foi a predominantemente afetada (gráfico 7).

Tabela 2 - Distribuição da porcentagem de crianças de acordo com a presença ou ausência da experiência de CPI nos dentes decíduos posteriores

\begin{tabular}{c||c|c||c|c}
\hline \hline \multicolumn{1}{c||}{} & \multicolumn{2}{c||}{ ceos - SIM } & \multicolumn{2}{c}{ ceos- NÃO } \\
\cline { 2 - 5 } \multicolumn{1}{c|}{ Faixa Etária } & $\mathbf{1}^{0}$ molar & 2o molar & $\mathbf{1}^{0}$ molar & 2o molar \\
& $\mathbf{n}(\%)$ & $\mathbf{n}(\%)$ & $\mathbf{n}(\%)$ & $\mathbf{n}(\%)$ \\
\hline $\mathbf{0 - 1 2}$ & $0(0)$ & $0(0)$ & $0(0)$ & $0(0)$ \\
$\mathbf{1 3 - 2 4}$ & $1(0,22)$ & $0(0)$ & $446(99,78)$ & $0(0)$ \\
$\mathbf{2 4 - 3 6}$ & $5(1,11)$ & $4(0,89)$ & $442(98,89)$ & $443(99,11)$ \\
$\mathbf{3 7 - 4 8}$ & $23(5,14)$ & $42(9,39)$ & $424(94,86)$ & $405(90,61)$ \\
$\mathbf{4 9 - 6 0}$ & $9(2,01)$ & $32(7,15)$ & $438(97,99)$ & $415(92,85)$ \\
$\mathbf{6 1 - 7 1}$ & $4(0,89)$ & $12(2,68)$ & $443(99,11)$ & $435(97,32)$ \\
\hline
\end{tabular}


Crianças com Cárie (\%)

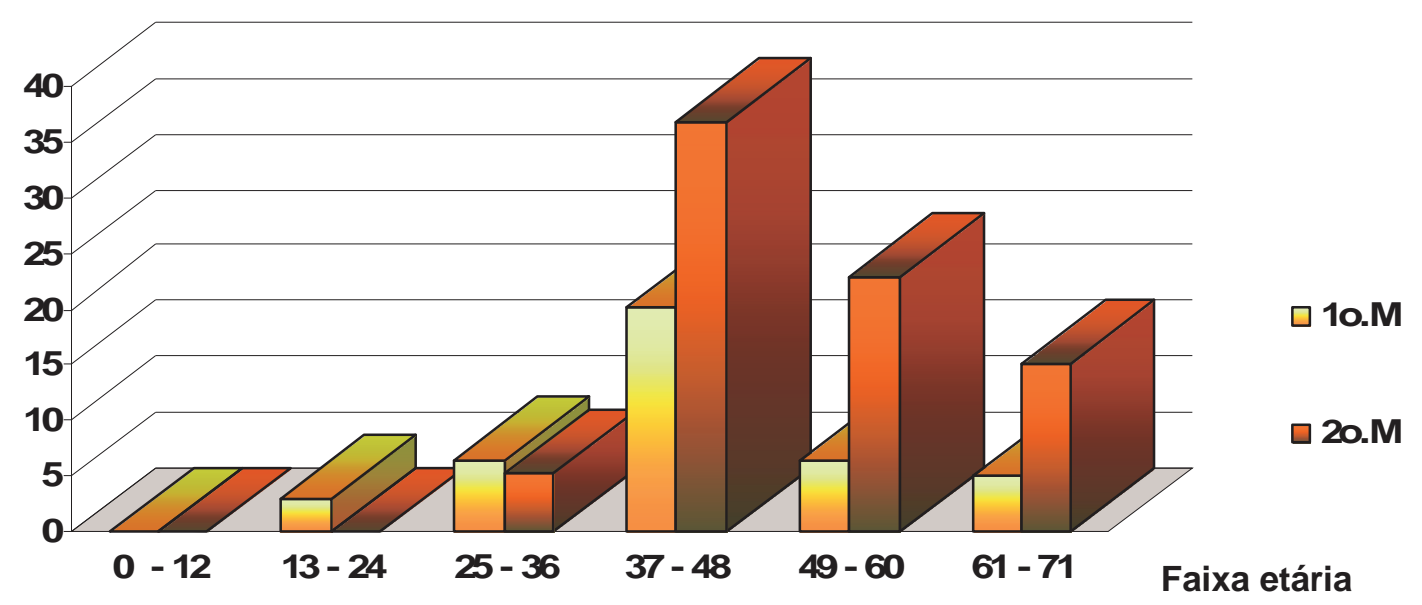

Gráfico 6- Distribuição da porcentagem de crianças de acordo com a experiência de CPI nos dentes decíduos posteriores

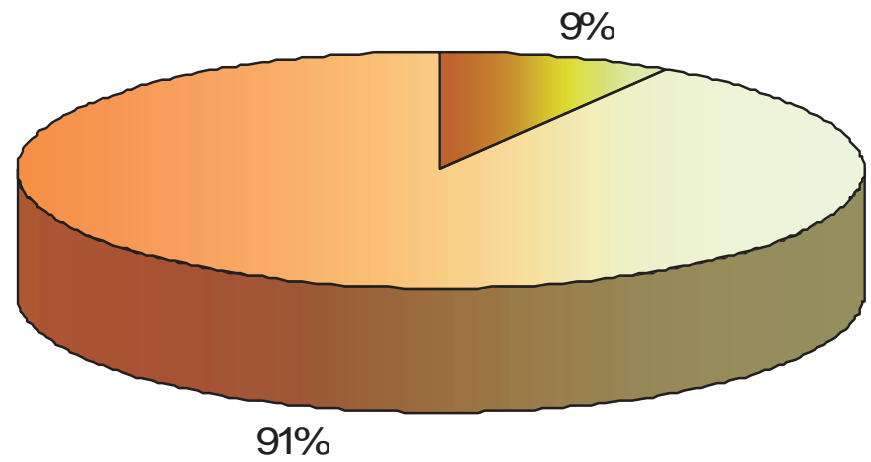

\author{
Experiência de \\ CPI Posterior \\ $\square$ PROXIMAL \\ $\square$ OCLUSAL
}

Gráfico 7- Distribuição da porcentagem de crianças de acordo com a experiência de $\mathrm{CPI}$ nas superfícies dos dentes decíduos posteriores 
A experiência de CPI (sim) e de IPV (sim) na amostra total nas regiões anterior, posterior e anterior/posterior, é demonstrada pela porcentagem de crianças que apresentavam tal condição bucal (gráfico 8).

CPI E IPV

(\%)

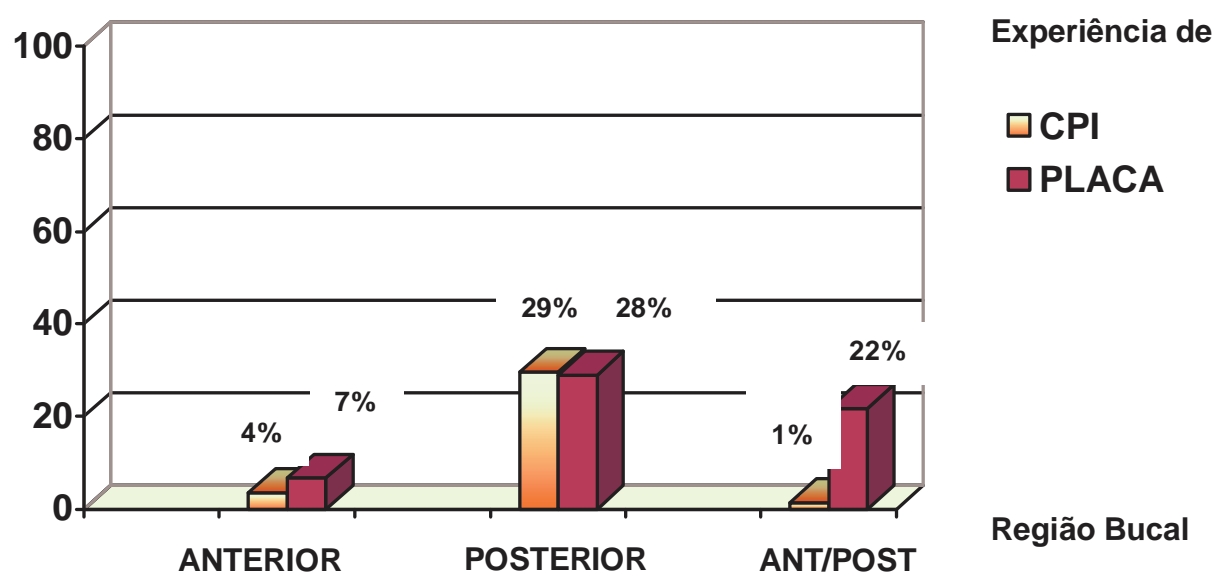

Gráfico 8 - Distribuição da porcentagem de crianças na amostra total com experiência de CPI e IPV

5.3 Análise Descritiva dos Índices de Saúde Bucal na Amostra Total (0 a $71 \mathrm{~m})$ : ceos, IPV e ISG

A experiência de CPI nas crianças aumentou com a idade, sendo maior na faixa dos 37 a 48 meses. Nota-se que embora a experiência de cárie encontrada na amostra estudada não tenha sido muito alta, ela já estava presente nos bebês mais novos (tabela 3 e gráfico 9). 
Tabela 3 - Experiência de CPI na amostra total, quanto à faixa etária

\begin{tabular}{c||c|c}
\hline \multicolumn{1}{c||}{} & \multicolumn{2}{c}{ ceos } \\
\cline { 2 - 3 } \multicolumn{1}{c||}{ Faixa Etária } & média & Dp \\
\hline $0-12$ & 0,25 & 0,5 \\
$13-24$ & 0,15 & 0,36 \\
$25-36$ & 0,59 & 2,36 \\
$37-48$ & 1,09 & 2,41 \\
$49-60$ & 0,85 & 2,17 \\
$61-71$ & 0,75 & 1,57 \\
\hline
\end{tabular}

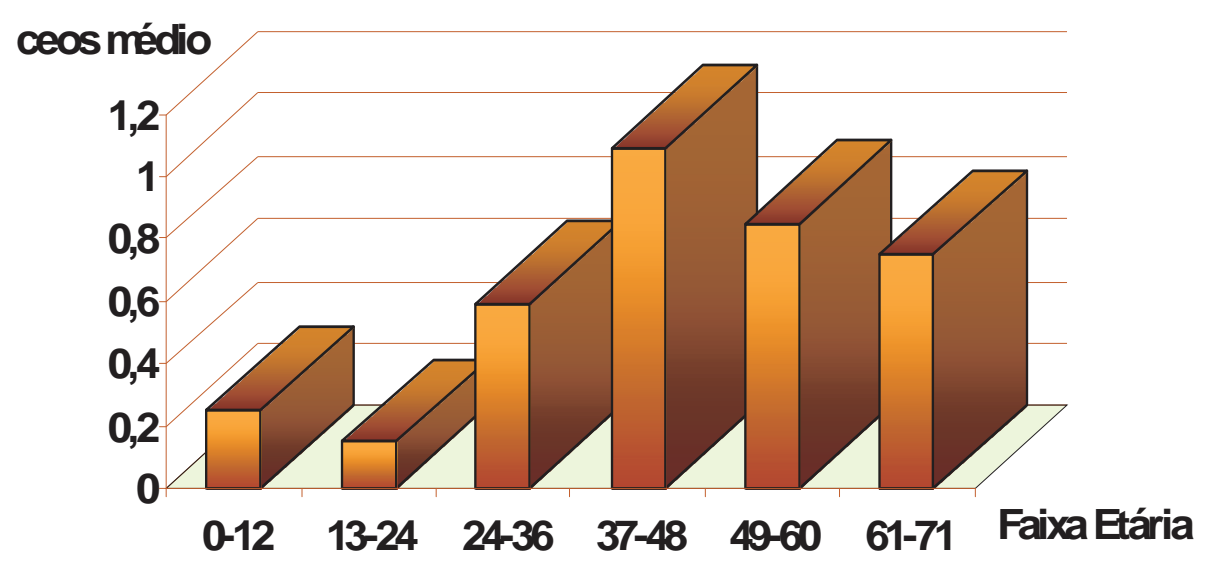

Gráfico 9 - Experiência de CPI na amostra total, quanto à faixa etária

A presença de placa visível na amostra total dos 24 ao 71 meses mostra uma distribuição aparentemente homogênea, envolvendo um porcentual ligeiramente superior à metade de crianças com placa visível para cada faixa etária (tabela 4 e gráfico 10). 
Tabela 4 - Distribuição das crianças amostra total por faixa etária, quanto à placa visível

\begin{tabular}{|c|c|c|c|c|c|}
\hline \multirow[b]{2}{*}{ Faixa Etária } & \multicolumn{2}{|c|}{ IPV - SIM } & \multicolumn{2}{|c|}{ IPV - NÃO } & \multirow[b]{2}{*}{ Total } \\
\hline & $\mathbf{n}$ & $\%$ & $\mathbf{n}$ & $\%$ & \\
\hline $0-12$ & 04 & 100 & 0 & 0 & 04 \\
\hline $13-24$ & 11 & 33 & 22 & 67 & 33 \\
\hline $24-36$ & 48 & 62 & 29 & 38 & 77 \\
\hline $37-48$ & 65 & 57 & 49 & 43 & 114 \\
\hline $49-60$ & 83 & 59 & 57 & 41 & 140 \\
\hline $61-71$ & 45 & 56 & 34 & 44 & 79 \\
\hline$\overline{\text { Total }}$ & 256 & 57 & 191 & 43 & 447 \\
\hline
\end{tabular}

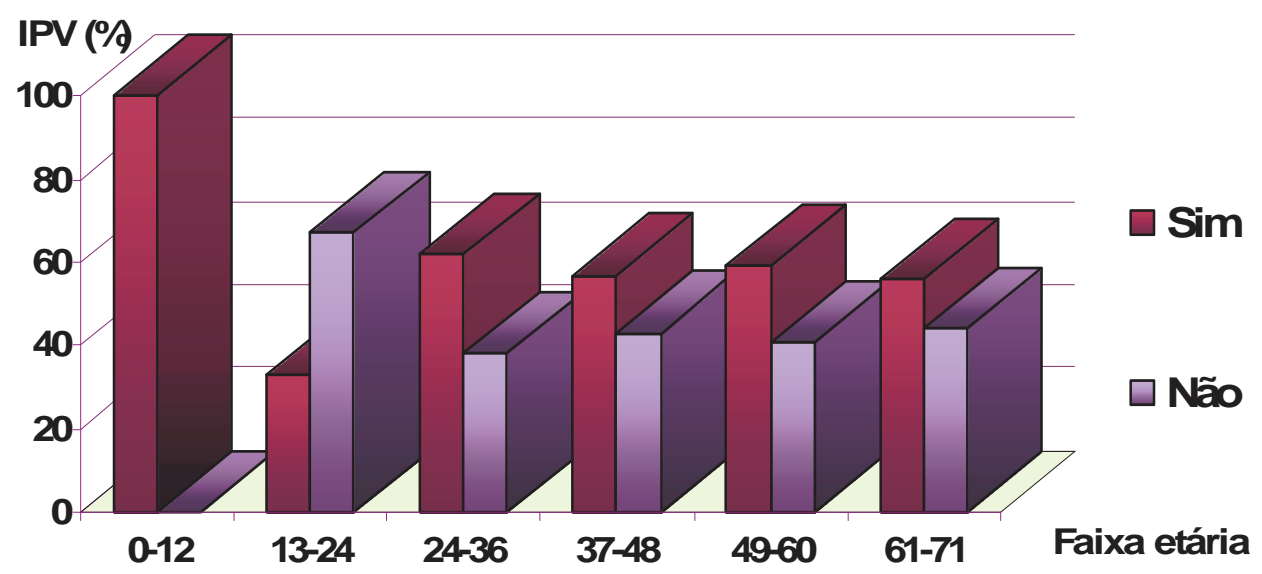

Gráfico 10 - Distribuição das crianças da amostra total por faixa etária, quanto à placa visível

O ISG foi aplicado em todas as crianças a partir dos 3 anos de idade e, não foi verificado sangramento em nenhuma área examinada de todas as crianças participantes desta etapa. 


\subsection{Análise Estatística dos Índices de Saúde Bucal: ceos e IPV}

A comparação entre as amostras dos dois municípios quanto aos dois índices de saúde bucal estudados mostra que para ambos houve uma diferença significante, com os menores valores encontrados para as crianças de Alfenas (Tabela 5).

Tabela 5 - Índices de saúde bucal das crianças entre os dois municípios e parâmetros da análise pelo teste t Student

\begin{tabular}{cccccc}
\hline \hline Índices & Areado & Alfenas & $\mathrm{t}$ & $\mathrm{GL}$ & $\mathrm{P}$ \\
\hline \hline ceo-s & $1,27 \pm 2,87$ & $0,70 \pm 1,90$ & 2,1433 & 445 & $0,0326{ }^{*}$ \\
IPV $(\%)$ & $12,71 \pm 13,85$ & $4,47 \pm 5,30$ & 8,7295 & 445 & $0,000{ }^{*}$ \\
\hline * $=$ estatisticamente significante & & & &
\end{tabular}

${ }^{*}=$ estatisticamente significante

Considerando-se os tipos de escola analisados dos dois municípios juntos, observou-se que não houve diferença estatisticamente significante entre elas quanto aos índices bucais de cárie e placa. Assim, o ceos foi de 0,70 \pm 1,46 (escola privada) $x 0,83 \pm 2,30$ (escola pública), com $p=0,5642$. Para o IPV (\%), os resultados foram de 5,03 \pm 9,72 (escola privada) x 6,14 \pm 7,24 (escola pública), com $p=0,1879$.

Foi então analisado se a presença ou não de assistência odontológica nas escolas teria influência sobre esses dois índices de saúde bucal, considerando-se os dois municípios juntos. Cabe lembrar, que todas as escolas de Areado e todas as escolas privadas de Alfenas, que foram analisadas não apresentavam assistência odontológica aos seus alunos. Os resultados são mostrados na tabela 6.

Tabela 6- Índices de saúde bucal das crianças segundo a presença de assistência odontológica e parâmetros da análise pelo teste t Student

\begin{tabular}{|c|c|c|c|c|c|}
\hline Índices & $\begin{array}{c}\text { Com } \\
\text { Assistência }\end{array}$ & $\begin{array}{c}\text { Sem } \\
\text { Assistência }\end{array}$ & $\mathrm{t}$ & GL & $p$ \\
\hline ceo-s & $0,70 \pm 2,10$ & $0,93 \pm 2,09$ & 1,1506 & 445 & 0,2505 \\
\hline IPV (\%) & $4,34 \pm 5,54$ & $8,06 \pm 10,29$ & 4,9433 & 445 & 0,0000 * \\
\hline
\end{tabular}

${ }^{*}=$ estatisticamente significante 
Foi então analisado, se haveria diferenças para os índices de saúde bucal estudados, considerando-se o fator tipo de escola e a presença de assistência odontológica, para cada um dos municípios isoladamente. A assistência odontológica só foi verificada e estudada em Alfenas.

Os resultados dessas análises para Alfenas (escola privada x pública e, sem $\mathrm{x}$ com-assistência odontológica) coincidem, visto que a assistência odontológica só foi verificada nas escolas públicas deste município. Assim, para Alfenas, nenhum desses dois fatores exerceu influência significante para os índices estudados: ceos de 0,70 $\pm 1,27$ (escola privada / sem-assistência odontológica) x 0,70 $\pm 2,10$ (escola pública / com-assistência odontológica), com $p=0,992$; IPV (\%) de 4,81 \pm 4,63 (escola privada / não-assistência odontológica) x 4,34 \$ 5,54 (escola pública / comassistência odontológica), com $\mathrm{p}=0,431$.

Os resultados da análise da influência do tipo de escola sobre os índices de saúde bucal em Areado são mostrados na tabela 7.

Tabela 7- Índices de Saúde Bucal das crianças segundo o tipo de escola no município de Areado

\begin{tabular}{cccccc}
\hline \hline & Escolas & Escolas & & & \\
Índices & Públicas & Privadas & $\mathrm{t}$ & $\mathrm{GL}$ & $\mathrm{p}$ \\
\hline \hline ceo-s & $1,45 \pm 3,01$ & $0,72 \pm 2,35$ & $-0,931$ & 72 & 0,355 \\
IPV $(\%)$ & $14,77 \pm 8,19$ & $6,29 \pm 23,43$ & $-2,327$ & 72 & 0,023 * \\
\hline
\end{tabular}

* = estatisticamente significante

\subsection{Análise Estatística da Influência de Fatores Indicadores do Risco à}

\section{Cárie, sobre o ceos na Amostra Total ( 0 a 71m)}

A seguir, serão apresentados os resultados da análise feita utilizando o teste do qui-quadrado, para avaliar a influência exercida por alguns fatores indicadores de risco à cárie estudada, sobre as seguintes situações: experiência de CPI (sim ou não), considerando-se as crianças dos dois municípios juntos. 
A experiência de CPI (sim ou não) na população estudada, não foi influenciada pelos fatores indicadores de risco a cárie estudados individualmente e relacionados a seguir:

- freqüência de escovação (adequada/inadequada) $(p=0,33408)$;

- tratamento com flúor tópico ( $\operatorname{sim} / n a ̃ o) ~(p=0,61435)$;

- freqüência do uso do fio dental (freqüente, às vezes e nunca) ( $p=0,92538)$;

- escovação (feita somente pela criança ou pela criança e um adulto) ( $p=0,87577)$;

- consumo de açúcar diário (até 3 vezes e mais que 3 vezes ) ( $p=0,77970$ );

- uso de mamadeira durante a noite ( $\operatorname{sim} /$ não) $(p=0,54581)$;

- conteúdo da mamadeira (leite puro e leite associado a carboidrato) ( $p=0,66542)$;

- uso de líquidos adocicados na mamadeira ( $\operatorname{sim} / n a ̃ o) ~(~ p=0,38834)$;

- presença de fumantes na residência ( $\operatorname{sim} /$ não) $(p=0,1366)$ e,

- pelo nível sócio-econômico, classificado em seis diferentes categorias (baixo inferior, baixo superior, médio inferior, médio, médio superior e alto) ( $p=0,69432)$.

A experiência de cárie (sim ou não) na população estudada foi influenciada significantemente pelos fatores indicadores de risco a cárie estudados individualmente e relacionados a seguir, nas tabelas 8 e 9.

Tabela 8 - Influência do gênero na experiência de cárie, analisada pelo teste do quiquadrado

\begin{tabular}{cccc}
\hline \hline Gênero & Ceos $=0$ & Ceos $>0$ & $\mathbf{P}$ \\
& $\mathbf{n}(\%)$ & $\mathbf{n}(\%)$ & \\
\hline \hline feminino & $160(72,1)$ & $62(28,0)$ & 0,00529 * \\
masculino & $134(59,6)$ & $91(40,4)$ & $0,01 \%$ \\
\hline
\end{tabular}

* $=$ estatisticamente significante 
Tabela 9 - Influência da freqüência de visitas ao CD, na experiência de cárie, analisada pelo teste do qui-quadrado

\begin{tabular}{cccc}
\hline \hline Visitas ao CD & $\begin{array}{c}\text { Ceos }=\mathbf{0} \\
\mathbf{n}(\%)\end{array}$ & $\begin{array}{c}\text { Ceos>0 } \\
\mathbf{n}(\%)\end{array}$ & P \\
\hline \hline Sim & $44(51,8)$ & $41(48,2)$ & \\
Às vezes & $64(51,2)$ & $61(48,8)$ & \\
Não & $170(81,3)$ & $39(18,7)$ & 0,0000 * \\
\hline = estatisticamente significante & &
\end{tabular}

Observou-se que houve uma relação significante entre o fator gênero, com a experiência de cárie positiva, sendo que neste trabalho, esta relação foi encontrada para os meninos. Com relação à freqüência de visitas ao Cirurgião Dentista, também houve uma relação significante entre elas e a experiência de CPI ', sendo que neste trabalho esta relação foi encontrada para aquelas crianças que nunca procuravam o CD.

Todos os fatores indicadores do risco à cárie foram submetidos à análise de regressão Múltipla, como variáveis independente, para estudar a relação dos mesmos em conjunto, com a experiência de CPI (ceos) quantitativamente na população estudada (variável dependente). Empregou-se o método "Forward Stepwise" que identifica aquelas variáveis que são estatisticamente significantes nesta relação. De doze variáveis independentes estudadas, cinco apresentaram relação significante com a variável dependente, sendo três delas, com um valor de $B$ negativo. O modelo final encontrado foi significante $(p=0,0000)$, com um $R^{2}=26 \%$ (Tabela 10). 
Tabela 10- Fatores indicadores do risco à cárie com relação significante com a experiência de CPI, indicados pela análise de Regressão Linear Múltipla

\begin{tabular}{ccccc}
\hline \hline FIRC & B & DP & GL & p \\
\hline $\begin{array}{c}\text { Gênero } \\
\text { Freqüência }\end{array}$ & 0,962 & 0,2985 & 1 & 0,0013 \\
$\begin{array}{c}\text { Escovação } \\
+\end{array}$ & $-1,155$ & 0,2147 & 1 & 0,0000 \\
$\quad$ & & & & \\
Fio Dental & 0,476 & 0,2413 & 1 & 0,0485 \\
Fumante & $-1,042$ & 0,3374 & 1 & 0,0020 \\
Nível & & & & \\
Sócioeconômico & $-0,464$ & 0,1974 & 1 & 0,0187 \\
\hline
\end{tabular}

Análise de Regressão Linear Múltipla - significância do modelo $p=0,000$ e $\mathrm{R}^{2}=26 \%$

$\mathrm{FIRC}=$ fator indicador do risco à cárie

\subsection{Análise Estatística dos Índices de Saúde Bucal na Amostra Parcial}

(37 a $71 \mathrm{~m})$

Dentro desta amostra, verificou-se que $73,02 \%$ das crianças apresentavam-se livres de carie, ou com o ceos $=0$ enquanto que $26,97 \%$, um ceos $>0$. A análise do índice de cárie, também foi feita separando-se as crianças de acordo com a região bucal acometida por esse tipo de lesão (Tabela 11). Nesta tabela se observa que houve um predomínio de crianças com lesões posteriores, quando consideradas isoladamente, ou quando em conjunto com crianças que também apresentavam lesões anteriores. As proporções de crianças que se enquadram nestas duas situações podem ainda ser analisadas diante da amostra total (341 crianças), e somente da amostra com ceos $>0$ (92 crianças), revelando novamente o predomínio absoluto da proporção de crianças portadoras de CPI posterior. 
Tabela 11 - Distribuição das crianças de 37 a 71 meses de acordo com o índice de cárie, dos municípios de Alfenas e Areado juntos

\begin{tabular}{|c|c|c|c|}
\hline Situação & $\bar{n}$ & $\begin{array}{c}\% / 341 \\
\text { (amostra total) }\end{array}$ & $\begin{array}{c}\% / 92 \\
(\text { ceos > } 0)\end{array}$ \\
\hline ceos $=0$ & 249 & 73,02 & - \\
\hline $\operatorname{ceos} A>0$ & 06 & 1,75 & 6,52 \\
\hline $\operatorname{ceos} \mathrm{P}>0$ & 81 & 23,75 & 88,04 \\
\hline $\operatorname{ceos} \mathrm{A}+\mathrm{P}>0$ & 05 & 1,46 & 5,43 \\
\hline $\operatorname{ceos} A+P>0+\operatorname{ceos} P>0$ & 86 & 25,21 & 93,47 \\
\hline
\end{tabular}

Foi feita uma análise desses grupos apresentados na tabela 11, com relação aos valores encontrados para o ceos, buscando verificar se a presença de CPI anterior teria alguma influência na experiência de CPI posterior encontrada. Verificou-se que o ceos do grupo de crianças que só apresentava CPI posterior foi de 0,45 , enquanto que o ceos $P(A+P)$, (ceos posterior, do grupo de crianças que apresentava CPI anterior e posterior), foi de 0,051. A diferença entre esses valores foi significante $(p=0,005)$, identificada pelo teste de Mann-Whitney. O ceos total encontrado para o do grupo $A+P$ foi de 0,49 , e o ceos do grupo de crianças que só apresentava CPI posterior foi de 0,45 . Os valores encontrados foram muito semelhantes entre si. 



\section{Discussão}





\section{DISCUSSÃO}

\subsection{METODOLOGIA EMPREGADA}

No Brasil, a cárie dental continua sendo uma das doenças de maior incidência e prevalência, tanto na infância quanto na idade adulta. Diversos fatores influenciam, potencializam ou amenizam sua ocorrência, sendo a placa bacteriana o principal deles. A OMS (1997) preconiza que a faixa etária pré-escolar é a ideal para monitoramento da prevenção da cárie, dos padrões de saúde bucal e para se avaliar os programas preventivos a serem desenvolvidos na população infantil.

Apesar de um declínio da cárie dentária no país, observado em um levantamento nacional (BRASIL, 2004), estes dados são desiguais nas diferentes regiões do país e ainda são valores considerados altos, sobretudo nas faixas etárias de 18 a 36 meses e na idade de 5 anos. Há a necessidade urgente de dados nacionais recentes relacionados à epidemiologia da cárie na faixa etária de 0 a 5 anos, já que existem apenas estudos isolados em alguns locais do país. (CARVALHO et al., 2002; SERRATINE et al., 2003; VOLPATO; FIGUEIREDO, 2005; BRANDÃO et al., 2006; OLIVEIRA et al., 2008). Como o exame odontológico não é tão acessível à criança pré-escolar como às crianças de idade escolar, isso explicaria os poucos estudos disponíveis na literatura. Por esta razão, no presente estudo, avaliou-se crianças pré-escolares até a idade de 71 meses (5 anos) de duas cidades interioranas do sul de Minas Gerais, Alfenas e Areado. Além desta dificuldade, acrescenta-se que o uso de diferentes metodologias nos estudos epidemiológicos de cárie envolvendo crianças nesta faixa etária, dificulta ainda mais a comparação dos resultados obtidos. Outros fatores ainda podem interferir, como diferentes grupos etários, critérios divergentes para definição de cárie, ou seus indicadores, condições distintas para coleta dos dados, como luz, secagem prévia das superfícies, complicando ainda mais as comparações. Todos esses componentes de uma pesquisa epidemiológica enfatizam ainda mais o caráter multifatorial da cárie. (BRANDÃO et al., 2006). 
De uma perspectiva epidemiológica, o exame dos sinais precoces de cárie é difícil de realizar, pois um diagnóstico acurado depende de condições clínicas apropriadas, o que é muito dificultado pela idade das crianças (SCAVUZZI et al., 2007) e pelas condições de exame encontradas nos diferentes locais. Como a maioria das crianças da amostra era da cidade de Alfenas, e destas, grande parte pertencia à rede pública de ensino, que presta atendimento odontológico, elas já estavam acostumadas à abordagem odontológica, não dificultando a realização do exame. No entanto, todos os exames foram realizados em ambiente fechado de cada instituição envolvida, sob iluminação natural, o que torna muito difícil o exame acurado de uma lesão inicial de cárie. Por essas razões, o índice escolhido foi o ceos, de aplicabilidade comprovada em vários estudos (O'SULLIVAN, TINANNOFF, 1993, CERQUEIRA et al, 1999; AL-BANYAN et al, 2000; BONECKER et al, 2000; CARVALHO et al, 2002; DAVIDOFF, ABDO, SILVA, 2005; BONECKER, 2005; GRADELLA et al, 2007; SCAVUZZI et al 2007; OLIVEIRA et al, 2008 e com a vantagem de apresentar maior sensibilidade e poder de discriminação, sobretudo, em levantamentos epidemiológicos de populações de baixa prevalência de cárie, como a encontrada neste trabalho, visto que considera todas as superfícies dentárias. (PINTO, 2008). Este índice foi empregado conforme os critérios propostos pela OMS (1997), tendo sido avaliadas 88 superfícies dentárias, sendo 5 em cada dente posterior e 4 em cada dente anterior. Por ser este trabalho de delineamento transversal, os dados colhidos através do índice ceos, são referidos como "experiência de CPI". Conforme a definição adotada pela Associação Americana de Odontopediatria, já descrita no capítulo de Revisão da Literatura, neste estudo foram observadas lesões de cárie que se encaixam numa classificação ampla denominada de CPI e também especificamente, como CPI-S. A denominação de CPI-S é dada para enfatizar a lesão mais severa, que é classificada de acordo com o seu tipo e a idade da criança, cuja definição é englobada pela definição da CPI. Neste estudo será empregado normalmente o termo CPI, e eventualmente, os termos CPI+CPI-S, sobretudo quando em comparações com outros trabalhos que fazem esta distinção, visto que foi observada a presença de CPI-S, em várias crianças também.

Uma melhor avaliação do grau de saúde bucal de uma criança deve considerar índices que avaliem a história de cárie presente, o acúmulo de biofilme, associado a índices que avaliem a condição gengival. A avaliação apenas do 
biofilme pode resultar numa informação não confiável a respeito da qualidade de higiene bucal da criança, pelo fato da mãe da mesma realizar uma melhor higiene de sua boca, se souber que a criança será examinada por um profissional, conforme relato de Santos, Soviero (2008). No entanto é sabido que o acúmulo de biofilme dentário está relacionado à cárie dentária (ALALUUSUA, MALMIVIRTAZ, 1994) e à gengivite, relatado por Santos, Soviero (2008). Embora os microrganismos responsáveis pela gengivite sejam diferentes dos causadores da cárie, a gengivite é um indicador de prática infreqüente de higiene oral e está relacionada à progressão da cárie. (AAPD, 2007). Além disso, a presença de placa visível em pré-escolares pode ser usada como indicador de risco de cárie em crianças muito jovens (TINANOFF et al., 2002), já que a CPI se desenvolve em superfícies lisas (RIPA, 1986), que são facilmente acessíveis à rotina de escovação. A formação da placa determina redução do $\mathrm{pH}$ da boca e induz desmineralização do esmalte dentário que culmina na formação da cavidade. (PASAREANU, 2007).

Os índices que avaliaram acúmulo de biofilme e sangramento gengival neste estudo são considerados binários ou dicotômicos, pois avaliam a presença ou ausência da variável clínica em estudo. Eles são fáceis, rápidos de serem administrados, e de pouca subjetividade, pois não quantificam a variável clínica e sim anotam simplesmente a presença ou ausência da variável como 0 (zero) ou 1 (um). (GALGUT, 1999). Esta é uma característica ideal para levantamentos feitos em campo, ou seja, ambientes sem nenhuma sofisticação de recurso técnico.

O índice para avaliar o biofilme dentário neste estudo foi o de Ainamo, Bay (1975), denominado de Índiced de Placa Visível, que pode ser empregado em todos os dentes conforme já descrito no capítulo de material e métodos. A identificação do biofilme deve considerar aquele claramente visível além de qualquer dúvida, pois como já demonstrado por Alaluusua, Malmivirta (1994), este tipo de acúmulo é reconhecido fator de risco á cárie e sobre o qual deve recair a preocupação do profissional.

Mesmo quando a doença periodontal está presente na infância, nem sempre suscita nos profissionais que atendem a população infantil, uma preocupação. Esse tipo de negligência normalmente é motivado pela crença de que as crianças não apresentam alterações periodontais, com implicações mais sérias, e mesmo, que 
não haveria necessidade de uma preocupação com o tratamento dentário. Contudo a prevenção, detecção e o tratamento da gengivite quando realizados precocemente, têm a possibilidade de evitar a doença periodontal, nas crianças, e, portanto, garantir uma população adulta com elevado nível de saúde bucal. (SCAVUZZI et al, 2001). O índice de sangramento gengival é um sinal objetivo e de fácil detecção das alterações gengivais, aceito por grande número de profissionais. (TINOCO, GJERMO, 1992; FRITSCHER, ARAÚJO, FIGEIREDO, 1999; TOASSY, PETRY, 2002; FELDENS et al 2006; SANTOS et al, 2008; SANTOS, SOVIERO, 2008). Pelas vantagens já descritas, ele tem sido amplamente utilizado em levantamentos epidemiológicos. Normalmente é empregado para detectar alterações gengivais em crianças com idade igual ou superior a 5 anos de idade. (TINOCO, GJERMO, 1992; PEREIRA, 2003; LEITE et al, 2004; GOMES-FILHO et al, 2006). Neste estudo, foi utilizado o índice de Carter e Barnes (1974) que emprega o fio dental não encerado nas áreas interproximais mesiais e distais de todos os dentes, para detectar a presença ou ausência de sangramento no sulco gengival. Este índice foi também preconizado para crianças (LEITE et al, 2004, SANTOS, SOVIERO, 2008), pois a distribuição e desenvolvimento de gengivite nelas são diferentes do que ocorre em adultos. Desse modo é necessário um índice de alta sensibilidade para detectar graus mais leves de alterações gengivais, características preenchidas pelo índice que emprega o fio dental. (TINOCO, GJERMO, 1992). No entanto, o que se relata Santos, Soviero, (2008) na literatura, é a falta de concordância entre os autores na escolha dos índices que avaliam a presença do biofilme dentário e de alterações gengivais em crianças. Por esse motivo, nesta população em que o comportamento nem sempre é de colaboração, deve-se optar por índices que sejam rapidamente aplicados, reprodutíveis e, práticos, como já salientado.

Todos os exames clínicos, neste estudo, foram realizados por um único pesquisador, devidamente calibrados, seguindo a mesma tendência que outros trabalhos. (TOMITA et al, 1996; LEITE et al, 1999; BARROS et al, 2001, TOASSY, PETRY, 2002; AZEVEDO et al., 2005; DAVIDOFF, ABDO, SILVA, 2005; RIBEIRO, OLIVEIRA, ROSENBLATT, 2005; BRANDÃO et al., 2006; FELDENS et al, 2006; SORAGGI et al, 2007; KRAMER et al, 2008.) Foi adotado um grau de reprodutibilidade entre os exames dados pelo índice kappa, em torno de 0,80. 
Estudos que envolvem vários locais e uma amostra maior exigem uma maior quantidade de examinadores (O'SULLIVAN; TINANOFF, 1993a, 1993b, 1996; REISINE et al., 1994; SCHOU, UITEMBROEK, 1995; HALLET, O'ROURKE, 2002, 2003; AZEVEDO et al., 2005; BRANDÃO et al., 2006; OLIVEIRA et al., 2008; QIN et al., 2008), o que não foi o caso do presente estudo, devido ao tamanho restrito da amostra, de 447 crianças, divididas em dois municípios.

A identificação do grau de saúde bucal de uma determinada população infantil, além de ser demonstrada pelos índices de saúde bucal empregados, examinados diretamente na criança, pode ser estudado através de uma pesquisa junto aos pais/responsáveis, sobre inúmeros fatores sócio-comportamentais, que também estão envolvidos na etiologia das principais doenças bucais: cárie dentária e gengivite. A finalidade desta abrangência é permitir traçar metas e estabelecer estratégias de ações multidisciplinares na prevenção, tratamento e controle dos problemas encontrados. No entanto o estudo dos fatores de risco às doenças bucais não é simples, pois envolve estudos longitudinais. Pela definição de Fator de Risco entende-se: "Fator ambiental, comportamental ou biológico, confirmado por uma sequência temporal, comumente em estudos longitudinais, que se presente aumenta diretamente a probabilidade da ocorrência da doença, e se ausente ou removido, reduz a probabilidade. Os fatores de risco são parte da cadeia causal, ou expõem o hospedeiro à cadeia causal. Uma vez que a doença ocorra, a remoção do fator de risco, pode não resultar na cura". (BECK, 1998). O presente estudo foi desenvolvido com um delineamento transversal, portanto os fatores pesquisados são denominados, com Indicadores de Risco. Um indicador de risco pode ser um fator de risco provável, pois os dados transversais nos quais ele se baseia são mais fracos do que os resultados de estudos longitudinais. (BURT, 2001).

Para que a possibilidade e a probabilidade da prevenção atinja 100\%, a criança deveria ingressar num programa preventivo com menos de 12 meses de idade e sem presença de fatores de risco. Este fato indica que a educação prévia dos pais é um dos fatores mais importantes na manutenção da saúde bucal. Levando em conta se tratar de pacientes de pouca idade, é a conduta dos pais que determina o inexistente ou baixo risco da criança em adquirir a cárie dentária. A reversão do risco também é eficaz na manutenção da saúde bucal, principalmente quando acontece nos primeiros 6 meses de acompanhamento da criança. 
(WALTER, NAKAMA, 1998). Todavia, uma vez que o padrão de cárie ou os fatores necessários para iniciação da cárie estejam estabelecidos, eles são mais difíceis de serem revertidos. (O'SULLIVAN, TINANOFF, 1993; REISINE et al., 1994). O presente estudo, por ter tido um delineamento transversal como Feitosa, Colares (2004), Davidoff, Abdo, Silva, (2005), Adekoya-Sofowora, Nasir, Adesina, (2006); Maciel et al, (2007), Kramer, (2008), em que os exames bucais e a pesquisa junto aos pais foram feitos uma única vez, procurou através da aplicação de um questionário aos pais, sem a supervisão do pesquisador, identificar os fatores indicadores de risco à cárie que poderiam ter algum significado com a situação de saúde bucal encontrada nas crianças. A utilização de um questionário estruturado, com respostas em alternativas fechadas, realizada neste estudo, também foi empregada por diversos pesquisadores, tanto nacionais (BARROS et al, 2001; RIBEIRO OLIVEIRA ROSENBLATT, 2005; THEODORO et al, 2007; MACIEL et al, 2007; KRAMER, 2008), como internacionais. (O'SULLIVAN; TINANOFF, 1993 a, 1993b; REISINE et al., 1994; SCHOU, UITEMBROEK, 1995; HALLET; O'ROURKE, 2002, 2003; ADEKOYA-SOFOWORA, NASIR, ADESINA, 2006; DECLERK, 2008; QIN et al., 2008).

\subsection{DISCUSSÃO DOS RESULTADOS ENCONTRADOS}

\subsubsection{ANÁLISE DESCRITIVA}

\section{Amostra total: Alfenas x Areado}

Em geral o atendimento infantil no serviço público inicia-se na idade escolar (MARTINS, ARAÚJO, VELOSO, 1999). No entanto em Alfenas todas as creches públicas avaliadas, recebiam o atendimento odontológico educativo/preventivo, com palestras sobre educação em saúde bucal e ensino de técnica de escovação (TINANOFF et al, 2002; TOASSY, PETRY, 2002; GRADELLA et al, 2007; SORAGGI, et al, 2007; SANTOS et al, 2008), na própria instituição, oferecido por alunos de graduação, como parte de um estágio curricular obrigatório, durante o ano 
letivo. Em Areado nenhuma instituição participante do estudo recebia qualquer atendimento deste gênero. Desse modo foi possível avaliar se esta atividade educativa/preventiva teria alguma influência sobre o nível de saúde bucal das crianças dos dois municípios. $\mathrm{Na}$ Odontologia algumas prioridades são estabelecidas em relação a determinadas doenças, grupos populacionais por faixa etária, situação econômica e tipo de serviço prestado à comunidade. Com relação à situação econômica e considerando-se o alto custo dos serviços odontológicos privados, a população de baixa renda recebe atenção prioritária dos serviços públicos. Porém o setor público ainda não está preparado para a demanda da população específica de pré-escolares, necessitando, portanto, de profissionais mais capacitados. (GRACIANO, 1980, BONECKER et al, 1997, TINANOFF et al, 2002; MACIEL et al, 2007; MENEGHIM et al, 2007). No presente estudo, como já salientado, a atenção oferecida era proporcionada por alunos de graduação e não por profissionais contratados, retratando uma situação diferente, do que normalmente se encontra, o que foi constatado em Areado, em que a atenção odontológica é somente oferecida às crianças escolares.

No presente estudo, nos dois municípios envolvidos, a distribuição de crianças entre as escolas públicas e privadas considerando-se toda a amostra, (Gráfico 1) ou todas as faixas etárias (Gráfico 2) reflete de certo modo o nível sócioeconômico (NSE) da população, pois em ambos os casos há um evidente predomínio de crianças matriculadas em instituições públicas. A escola pública tem sido associada a um menor nível sócio-econômico da família, por vários autores. (GRACIANO, 1980, AL-KHATEEB et al, 1991; FREIRE, MELO, SILVA, 1996; CARVALHO et al, 2002; HOFFMANN et al, 2004; FEITOSA, COLARES, 2004; LEITE et al, 2004; BARBOSA et al, 2007; MENEGHUIM, 2007; FREIRE et al, 2009). Portanto, também foi possível estudar a influência deste fator, na amostra selecionada neste estudo. No entanto, a partir dos 60 meses essa situação muda, com um número bastante homogêneo de crianças matriculada nos dois tipos de instituição. Essa situação pode significar que com o aumento da idade da criança, ocorreria uma maior preocupação dos pais com a alfabetização de seus filhos e, aqueles pais com melhor situação sócio-econômica, os matriculariam na rede de ensino privada. 
Inicialmente foi distribuído em todas as pré-escolas/creches públicas e privadas de Alfenas e Areado, uma carta dirigida aos pais/responsáveis legais, sobre o tipo de trabalho que seria desenvolvido e um outro documento em que constava 0 consentimento formal livre e esclarecido dos mesmos (Anexo 2) para que a criança fizesse parte da amostra. No entanto, 447 retornaram o documento assinado, autorizando a participação no estudo. Assim, foi selecionada aleatoriamente a amostra, que casualmente apresentou uma homogeneidade entre meninas e meninos (Gráfico 3). Outros levantamentos epidemiológicos têm adotado esta mesma sistemática quando a amostra total não é tão numerosa. (TOASSI, PETRY, 2002; MOURA et al, 2009).

\section{Amostra total: Experiência de CPI e IPV}

De acordo com a definição oferecida pela Academia Americana de Odontopediatria de 2009, a lesão de cárie quando encontrada numa população que apresente a mesma faixa etária da amostra deste estudo é denominada como Cárie Precoce da Infância (CPI), que foi identificada, utilizando-se o índice ceos. Neste estudo, enquanto a maioria das crianças estava livres de experiência CPI, cerca de $34 \%$ delas apresentavam alguma experiência (Gráfico 4), confirmando achados de Gueiros, Silva (2003); Hoffmann et al (2004); Martins et al (2004); Davidoff, Abdo, Silva (2005); Ribeiro, Oliveira, Rosenblat (2005); Sofowora, Nasir, Adesina (2006); Barbosa et al (2007); Oliveira et al (2008); Melo et al (2009), que também identificaram uma distribuição polarizada da cárie. Neste tipo de distribuição, uma pequena parcela da população concentra as maiores necessidades de tratamento, especialmente a parcela menos favorecida economicamente. (FREIRE et al, 1996; CARVALHO et al, 2002; WEYNE, 2003; HOFFMANN et al, 2004; SOFOWORA, NASIR, ADESINA, 2006; BARBOSA et al, 2007). Na abordagem deste problema, é recomendado por Medeiros, Souza, Fonseca (1998); Cerqueira et al (1999); Leite et al (2004); Bastos (2006); Barbosa (2007); Soraggi et al (2007); Santos et al (2008), que haja uma interação de profissionais de saúde, educadores e pais, que poderão 
nortear novas práticas e almejar um futuro com menos desigualdade de distribuição de cárie dentária.

A distribuição da experiência de CPI nas diferentes idades mostra que ela se concentra dos 37 aos 48 meses de idade (Tabela 1 e Gráfico 5) concordando com alguns autores. (BARROS et al, 2001; GRADELLA et al, 2007). Portanto, essas crianças foram infectadas num período anterior, que pode ter correspondido à "janela da infectividade", dos 19 aos 31 meses. (CAUFIELD, CUTTER, DASANAYAKE, 1993; MEDEIROS, SOUZA, FONSECA, 1998; THEODORO et al, 2007). No entanto, é verificado que quando se trata de população de alto risco à cárie, a experiência de CPI apresenta um aumento estatisticamente significante, a partir dos 31 meses (NAKAMURA, 2009), revelando que a infecção pelos microorganismos cariogênicos, ocorreu mais precocemente. É interessante observar também que não só a experiência de CPI, mas também o número de crianças participantes aumentam com a idade. Contudo as faixas etárias dos 37 aos 60 meses concentram o maior número de crianças, embora dos 49 aos 60 meses, a proporção de CPI começa a cair. Essa distribuição em que a experiência de cárie aumenta com a idade é um fenômeno esperado e atestado por alguns autores. (TOMITA et al, 1996; MEDEIROS, SOUZA, FONSECA, 1998; CERQUEIRA et al, 1999; BARROS et al, 2001; SILVA et al, 2006; MAIA, et al, 2007; OLIVEIRA et al, 2008). A presença de um número maior de dentes na boca, o maior tempo deles em contato com os prováveis fatores de risco, a adoção pela criança da dieta familiar e um controle inadequado da higiene bucal estaria relacionado a este quadro. (TOMITA et al, 1996; MEDEIROS, SOUZA, FONSECA, 1998; VASCONCELOS et al 2004; BRANDÃO et al, 2006). A variação na experiência de CPI, mostrando uma queda a partir de determinado tempo observada neste estudo, também foi verificada em outros levantamentos como por Martins et al (2004), devido a um menor consumo de açúcar, mudanças no diagnóstico de cárie e melhorias nas condições socioeconômicas e Bönecker (2005), com uma melhoria da saúde bucal.

Considerando-se a amostra total, na faixa etária entre 37 e 48 meses de idade, observou-se uma maior ocorrência de CPI para ambos os dentes posteriores decíduos, sendo que para o segundo molar, a ocorrência foi maior que o dobro, em relação ao primeiro molar (Tabela 2 e Gráfico 6). Contudo até os 71 meses apesar do declínio da experiência de CPI, ela ainda prevaleceu para o segundo molar. 
Salienta-se ainda que de todas as superfícies, houve um predomínio de lesões na oclusal (91\%). (Gráfico 7). A superfície oclusal apresenta uma área de muitas irregularidades, de difícil limpeza pela localização do dente na boca e pelas características anatômicas próprias, que facilitam o acúmulo do biofilme dentário. Esses dados vão de encontro a outros longitudinais, que mostram que o segundo molar decíduo após 7,5 meses de seu irrompimento na cavidade bucal, apresentou o primeiro sinal de cárie. (NAKAMURA, 2009). Portanto, a rapidez em que se instala a lesão de cárie neste dente, contribui para essa ocorrência tão superior. Isso chama a atenção para a necessidade de uma proteção precoce específica para este dente, que deverá exercer suas funções na cavidade bucal aproximadamente até os 11 anos de idade e, mais ainda para a superfície oclusal. A ocorrência do predomínio de crianças afetadas por cárie em dente decíduo posterior foi verificada por Vasconcelos et al (2004) que também constataram o predomínio da superfície oclusal afetada e ainda por Sofowora, Nasir, Adesina (2006). Em levantamento longitudinal, de bebês com alto risco à cárie, Nakamura (2009) verificou que aos 3 anos de idade $58 \%$ das superfícies oclusais de primeiros e segundos molares estavam acometidas por cárie. No entanto nesta idade, os dentes mais afetados foram os incisivos centrais superiores, com resultado significante. Outros autores também verificaram a maior ocorrência de cárie em dentes anteriores decíduos. (O'SULLIVAN, TINANNOFF, 1993; BONECKER et al, 2000; BARROS et al, 2001; DAVIDOFF, ABDO, SILVA, 2005; RIBEIRO, OLIVEIRA, ROSENBLATT, 2005; SILVA et al, 2006; MACIEL et al, 2007).

Pelo Gráfico 8, observa-se que houve um acúmulo de IPV e CPI (considerando-se lesões de todas as superfícies) na região posterior, demonstrando uma tendência a associação causa-efeito, além da maior dificuldade dos pais executarem uma adequada higiene nos dentes posteriores de seus filhos, o que indica uma necessidade de atuação profissional educativa para modificar este quadro. 


\section{Amostra total: Índices de Saúde Bucal - ceos, IPV e ISG}

Quando se analisa a distribuição da experiência de CPI (ceos) por crianças nas diferentes faixas etárias, na amostra total, percebe-se novamente que entre os 37 e 48 meses foram encontrados os maiores valores de experiência de CPI (Tabela 3 e Gráfico 9). Contudo mesmo nesta faixa o valor encontrado não foi alto. A distribuição mostra um aumento com a idade, com o pico na faixa já citada e seguida de um declínio suave. O aumento da experiência de CPI com a idade foi verificado em outros estudos (SILVA et al, 2006; MAIA et al, 2007), sendo para alguns estatisticamente significantes. (BARROS et al 2001; GRADELLA et al, 2007; NAKAMURA, 2009). No presente estudo a distribuição da experiência de CPI por idade, no entanto, apresenta valores considerados baixos, embora a CPI já estivesse presente na faixa etária mais nova, dos 0 aos 12 meses. Esses dados contrariam outros de trabalhos nacionais (SILVA et al, 2006; MAIA et al, 2007; GRADELLA et al, 2007), que verificaram valores muito mais elevados de experiência de CPI (ceos) em faixas etárias correspondentes. Dentre estes autores citados, Maia et al (2007) desenvolveram o estudo em locais que não tinham água fluoretada, assim como Cerqueira et al (1999) e Martins et al (2006). Mais recentemente uma avaliação de bebês de alto risco à cárie, evidenciou um ceos= 0 até os 11 meses de idade. No entanto, até os 35 meses a experiência de CPI verificada (ceos) foi muito mais alta, sendo significante em relação à dos bebês mais novos (NAKAMURA, 2009). Os bebês deste último estudo pertenciam a famílias de baixo nível sócioeconômico, cujas mães eram portadoras de um elevado nível de infecção por estreptococos do grupo mutans. Alguns trabalhos apresentam a experiência de CPI avaliada pelo ceod, porém com valores que seriam maiores, se fosse feita a conversão para ceos, em bebês até 30 meses (BARROS et al, 2001), ou até 60 meses (MAIA et al, 2007). Neste estudo, embora a maioria das crianças pertencesse a famílias de nível sócio-econômico baixo, elas recebiam algum atendimento educativo/ preventivo, como já relatado, o que pode ter influenciado nos resultados encontrados. Os altos índices de CPI encontrados por diversos autores(já ciatados) em levantamentos epidemiológicos de regiões isoladas no Brasil podem ser atribuídos à falta de informação dos pais, dificuldade de acesso ao atendimento, 
ausência de um programa odontológico no serviço público que atenda essa faixa etária, ou mesmas razões não identificadas (MARTINS, ARAÚJO, VELOSO, 1999).

O acúmulo de biofilme dentário encontrado na amostra total (Tabela 4 e Gráfico 10) mostra um quadro interessante: presença de placa visível em todos os bebês (04) até 12 meses e, depois, uma distribuição homogênea entre os bebês de cada faixa etária, indicando que a presença da placa visível não sofreu influência da presença de mais ou menos dentes na boca. Para efeito de comparação, considerando-se a amostra total até os 36 meses de idade $(n=63)$, foi observado que $55,26 \%$ dela apresentava IPV, sendo esse resultado muito superior ao encontrado por Couto et al (2005), em 260 crianças de faixa etária similar, com apenas 35\% dela apresentando o IPV. No entanto este último autor só considerou a face vestibular dos incisivos superiores, enquanto no presente trabalho, foram analisadas todas as faces dentárias V, L e M, do lado direito da boca. Trabalhando com 302 crianças de 3 a 5 anos de idade, Scavuzzi et al (2001) encontraram 92,9\% da amostra acometida por placa visível, na superfície vestibular de todos os dentes decíduos, enquanto no presente trabalho, $57 \%$ da amostra total estava envolvida. Enfatiza-se que em Alfenas, município com o maior número de participantes, praticamente todos, recebia alguma atenção preventiva/educativa oferecida por graduandos em Odontologia. Percebe-se assim uma necessidade urgente de medidas educativas e formativas aos pais/responsáveis, para realizarem o adequado controle do biofilme dentário, em casa, na criança de idade pré-escolar, visto que a presença deste tipo de acúmulo orgânico tem sido associada ao risco de cárie. (ALALUUSUA, MALMIVIRTA, 1994). Dados epidemiológicos transversais (BARROS et al, 2001) mostraram que o aumento da quantidade de biofilme foi associado de forma significante ao desenvolvimento da cárie, em 74,12\% das crianças que apresentavam o maior escore de acúmulo de biofilme. De forma semelhante, Couto et al (2005), encontraram uma correlação positiva significante entre o IPV e o ceod.

A indicação mais significante da gengivite é a observação de determinados sinais clínicos (Carter, Barner, 1974). No entanto, a gengiva da criança durante a fase de dentadura decídua apresenta coloração mais vermelha que no adulto devido a uma vascularização mais abundante (Moura et al, 2009). A observação de sangramento gengival durante o exame clínico pode ser considerada um exame 
complementar no controle de lesões de CPI e, em especial, daquelas localizadas nas superfícies interproximais. O número de pontos de sangramento gengival orienta o clínico com relação ao controle do biofilme dental, agente etiológico das doenças periodontais e cárie dentária (Araújo et al, 2005). Neste estudo, o tecido gengival apresentou-se com aspecto saudável, sem nenhuma indicação clínica de reação inflamatória, sem tendência a sangrar por pressão ao passar o fio dental. $O$ valor encontrado para o ISG foi igual a zero para os dois municípios estudados. Analisando pré-escolares de 5 e 6 anos de idade de creches públicas de Belo Horizonte e, empregando a mesma técnica usada neste estudo para avaliar o ISG, Leite et al, (2004) encontraram $51,1 \%$ das crianças com sangramento gengival, especialmente na região de molares, provavelmente pela dificuldade de higienização, principalmente porque constataram que mais da metade das crianças não faziam uso do fio dental, em áreas de contatos justos. (FRITSCHER, ARAÚJO, FIGUEIREDO, 1999; SILVEIRA, OLIVEIRA, PADILHA, 2002; TOASSI, PETRY, 2002; LEITE et al, 2004; SILVA et al, 2006; SORAGGI et al, 2007; THEODORO et al,2007; PAREDES et al, 2009). A faixa etária estudada neste trabalho foi a partir dos três anos de idade, devido a uma provável maior colaboração da criança e, à presença da dentadura decídua completa. Porém como já salientado, o ISG é um indicativo da presença de CPI proximal e, neste estudo, foram encontradas poucas lesões deste tipo e, com mais freqüência, em crianças de 4 a 5 anos de idade (TINOCO, GJERMO, 1992; SCAVUZZI et al, 2001; LEITE, et al, 2004; SILVA et al ,2006). 57\% das crianças apresentassem IPV, (Tabela 4 e Gráfico 10), esta não pode ser relacionada ao desenvolvimento de doença periodontal nessas crianças, no momento em que este estudo foi desenvolvido. Pelo Gráfico 8, a presença de IPV predominantemente na região posterior pode ser um indicador clínico para o futuro desenvolvimento de problemas gengivais nesse local. 


\subsubsection{ANÁLISE ESTATÍSTICA -}

\section{Amostra total: Índices de Saúde Bucal - ceos e IPV}

Os menores valores dos índices de saúde bucal (ceos e IPV) encontrados em Alfenas (Tabela 5), provavelmente estejam relacionados a alguns fatores. Somente as crianças participantes de creches públicas estavam incluídas em um estágio curricular das Faculdades de Odontologia de Alfenas (UNIFAL e UNIFENAS) como já salientado anteriormente. Em Areado não existe nenhum programa preventivo em andamento voltado à população pré-escolar. Este programa constitui-se em prevenção à criança e educação aos pais. À criança: motivação em relação à higiene bucal com métodos simples e eficientes para a remoção do biofilme dental e prevenção das doenças bucais, a importância da dieta e alimentos, as características da cavidade bucal com saúde ou acometida pela doença, técnicas de escovação com macromodelos, com a participação dos alunos; a importância da escovação diária, uso do fio dental e a pasta dental, e, também, filmes sobre os dentes, para maior motivação da criança. Aos pais: são orientados sobre a importância da dentição, nutrição e dieta, CPI, doença periodontal. São os responsáveis pela saúde bucal de seus filhos, é essencial a educação à sua saúde para se conseguir melhores resultados com os filhos. Os pais são os modelos para os filhos e, portanto, precisam ser incentivados a monitorar a higienização bucal diária das crianças. A importância de progamas preventivos no controle do biofilme dentário (SANTOS et al, 2008) ou da cárie dentária (FREIRE et al, 1997), também tem sido demonstrada por outros autores, Bader et al, 2005; Adekoya-Sofowora et al, 2006; Gussy et al , 2006; Pasareanu, 2007; Simratvir et al, 2009. Apesar do IPV em Alfenas ser menor de forma significante, em relação ao de Areado, também foi observado que para todas as crianças havia uma alta prevalência de biofilme, sugerindo que a escovação, na quase totalidade delas, não está sendo efetiva, reforçando a necessidade de um adulto auxiliar na escovação dos dentes da criança. (SCAVUZZI, et al 2001; TINANOFF, KANELLIS, VARAGAS, 2002; LEITE et al, 2004; VASCONCELOS et al, 2004; MAIA et al, 2007; MOURA et al, 2009). 
O processo de controle da CPI envolve vários aspectos entre eles a atuação do $C D$, uma dieta adequada, balanceada e variada, uma reeducação materna e dos responsáveis pelas crianças em saúde bucal, fatores esses que ajudam na prevenção da CPI. Ações preventivas e educativas devem ser implementadas, orientando sobre uma escovação eficaz que controle adequadamente o biofilme dentário, já que ele está diretamente relacionado com a ocorrência de $\mathrm{CPI}$ e doença periodontal. (DAVENPORT, 1990; GALGUT, 1999; LÖE, SWITZERLAND, 2000; SCAVUZZI, et al, 2001; TOASI, PETRY, 2002; LEITE et al, 2004; SILVA et al, 2006; SANTOS, SOVIERO, 2008; MOURA et al, 2009). Além deste aspecto acima descrito que pode ter favorecido as crianças de Alfenas, aparentemente as crianças participante da amostra que freqüentavam creches públicas, deste município, apresentavam um nível sócio-econômico melhor que as de Areado no mesmo tipo de instituição. Existem evidências de que o baixo NSE está relacionado à história de cárie da criança. (GRACIANO, 1980; ARNLAUGSSON, MAGNUSSON, 1996; FREIRE et al, 1996; CARVALHO et al, 2002; TOMITA et al, 2007), ou ainda como relata Santos et al, (2008) a um pior nível de saúde periodontal.(SHOU, UITENBROEK, 1993; PETERSEN, 2005; ADEKOYA-SOFOWORA, 2006; FELDENS et al, 2006; DUMITRACHE, SFEATCU, BUZEA, 2008;

Embora se saiba que a escola pública se relacione ao NSE mais baixo, (TINOCO, GJERMO, 1992; FREIRE et al, 1996; GALGUT, 1999; CARVALHO et al, 2002), ao considerar os dois municípios juntos, comparando-os quanto ao tipo de escola (privada x pública), observou-se que não houve diferença estatisticamente significante entre elas quanto aos índices ceos e IPV, embora eles tenham sido pouco menores nas escolas privadas; concordando Carvalho et al, (2002) e Couto et al (2005). Esses dados, no entanto, diferem dos obtidos por Freire et al, (1996), trabalhando com pré-escolares de 0 a 6 anos de idade de creches públicas e privadas, em que os autores puderam constatar diferença significante entre a população com e sem cárie destas instituições, bem como entre o ceod nesses grupos de crianças. No presente estudo, deve ser enfatizado, que o número de instituições privadas e de crianças nelas matriculadas era bem menor que o levantado nas creches públicas o que pode ter influenciado o resultado obtido.

Em relação ao acesso à assistência odontológica, existem poucos estudos avaliando a contribuição dos serviços odontológicos para a melhoria dos níveis de 
cárie na população. (SHEIHAM, 1997; CANGUSSU et al, 2000; LEITE et al, 2004). Analisando os dois municípios juntos, sob esse parâmetro, observou-se no presente estudo que, o IPV foi o dobro nas escolas sem assistência odontológica e, embora não tenha sido verificada nenhuma diferença significante quanto ao ceos, ele também foi menor nas creches que recebiam assistência (Tabela 6).

Quando foram comparados os índices de saúde bucal (ceos e IPV) para o município de Alfenas isoladamente, verifica-se que a semelhança entre os valores encontrados reflete a similaridade da situação bucal dessas crianças. Embora a creche pública possa refletir uma situação de NSE inferior, e, portanto, piores índices de saúde bucal, como já salientado anteriormente, essas crianças vêm participando de programas preventivos oferecidos por graduandos em odontologia. Isso talvez tenha equilibrado a situação inicialmente desfavorável e, explique a homogeneidade dos dados finais. O programa que é desenvolvido, nas creches voltado aos pré-escolares (pais, professores), vai de encontro ao pensamento de Freire et al, (1996), que acredita ser este o lugar ideal para o desenvolvimento de programas de saúde bucal para esta faixa etária. A motivação gerada por programas educativos-preventivos tem grande importância na redução e controle do biofilme dentário, sendo muito mais efetiva se acompanhada de sessões de reforço com métodos simples e eficientes. Esse tipo de prática tem mostrado ser importante, para tornar a escovação dentária, uma rotina para a criança. (SCAVUZZI et al, 2001; SILVEIRA OLIVEIRA, PADILHA, 2002; TOASSI, PETRRY, 2002; VASCONCELOS et al, 2004; MAIA et al, 2007). A influência de um programa de saúde bucal, de aplicação continuada, pode ser melhor entendida, quando se observa os dados das comparações entre as escolas públicas e privadas de Areado (Tabela 7). Outro fato a se considerar é que, na primeira infância, a criança possui uma relação de dependência com o adulto, inserindo-se dentro do contexto sociocultural da família, o qual tem forte influência na definição das medidas de limpeza da boca a serem adotadas. A orientação das medidas de prevenção à cárie são funções que o cirurgião-dentista deve desenvolver, tendo em vista os comprovados efeitos destas orientações na promoção da saúde bucal dos indivíduos (CERQUEIRA et al , 1999).

Em Areado, como somente o fator NSE esteve atuante, é visível o efeito que o mesmo exerce, pois para ambos os índices, foram obtidos melhores resultados, para as crianças de escolas privadas. Esses dados remetem a duas reflexões 
importantes. A primeira delas, diz respeito à necessidade de programas de saúde bucal para a população de pré-escolares de instituições públicas, confirmando dados da literatura. (FREIRE et al, 1996; CARVALHO et al, 2002; LEITE et al, 2004). A segunda reflete uma relação já conhecida, pois se demonstrou que nas creches públicas de Areado, foram encontrados os maiores índices de cárie, embora não significantes e os maiores de IPV, estes sim significantes, indicando claramente a necessidade do controle do biofilme dentário nessa faixa etária, para a prevenção da CPI. (FRITSCHER, ARAÚJO, FIGUEIREDO, 1999; SCAVUZZI, et al, 2001; SILVEIRA, OLIVEIRA, PADILHA, 2002; TOASSY, PETRY, 2002; LEITE et al, 2004; COUTO et al 2008; SANTOS, SOVIERO, 2008).

\section{Amostra total: Fatores Indicadores do Risco à Cárie $x$ ceos}

Ao se analisar o resultado da análise estatística dos fatores indicadores de risco à cárie individualmente, pelo teste do qui-quadrado, é importante considerar que o questionário que pesquisava a presença de tais fatores na amostra deste estudo foi respondido pelos pais, sem a supervisão da pesquisadora, portanto, é de se esperar algum grau de subjetividade nas respostas. Outro aspecto que talvez tenha contribuído para a ausência de resultados significantes no estudo dos fatores indicadores de risco à cárie, é que a prevalência de lesões de cárie encontrada na população estudada não foi alta. Ambos os municípios têm água de abastecimento público fluoretada há 38 anos em Alfenas e há 25 anos em Areado e, além disso, no Brasil, desde o início da década de 90, todos os dentifrícios mais populares vendidos, têm seu teor de flúor controlado. Portanto as crianças deste estudo receberam estes benefícios desde o nascimento. Um terceiro fator que certamente também contribuiu para esses resultados foi que a maioria das crianças do estudo eram as que participavam do programa preventivo oferecido pelos graduandos das duas faculdades de odontologia de Alfenas.

No estudo dos fatores indicadores do risco à cárie, (Anexo 7), os dados coletados foram trabalhados de modo a transformá-los em alternativas fechadas, que permitissem uma análise estatística. A avaliação pelo teste do qui-quadrado 
mostrou que apenas dois fatores estudados apresentaram resultados significantes com a experiência de CPI (sim/não), na população estudada : o gênero masculino das crianças (Tabela 8) e a ausência de visitas feitas ao CD (Tabela 9 ). Resultados semelhantes aos demonstrados na tabela 8, porém não significantes foram encontrados em Londrina (WALTER, NAKAMA, 1999) e, em João Pessoa (RIBEIRO, OLIVEIRA, ROSENBLATT, 2005), com relação respectivamente: à incidência de $\mathrm{CPI}+\mathrm{CPI}$-S em crianças de 0 a 24 meses e, prevalência de $\mathrm{CPI}+\mathrm{CPI}-$ $\mathrm{S}$, em crianças de 48 meses. E ainda na Bélgica, (DECLERCK et al, 2008), em que se avaliou a experiência de $\mathrm{CPI}+\mathrm{CPI}-\mathrm{S}$ (ceod), com resultados significantes, nas crianças de 5 anos de idade. $O$ índice de CPI-S para crianças de 12 a 71 meses foi superior para as meninas, mas não significante. (LUCA, MUNTEANU, FARCASIU, 2008). De maneira semelhante à experiência de CPI+CPI-S (ceod) também foi maior e não significante para as meninas. (ADEKOYA-SOFOWORA et al, 2006). Observase claramente por esses resultados a diversidade de metodologias nos levantamentos epidemiológicos em pré-escolares, o que certamente dificulta a compreensão da exata dimensão dos problemas de saúde bucal neste grupo populacional. Pelos resultados encontrados no presente estudo, os programas de prevenção da CPI em pré-escolar, deveriam ter uma atenção maior para os meninos. Os meninos normalmente têm um temperamento mais agressivo que as meninas, oferecendo maiores dificuldades aos pais, durante a higienização bucal. Esse aspecto é na maioria das vezes suficiente para muitos pais desistirem de realizar a higiene bucal de seus filhos. Além disso, culturalmente, os meninos têm mais liberdade e menor atenção a aspectos relacionados à saúde pessoal.

Neste estudo, o segundo fator indicador de risco isoladamente que teve uma relação significante com a experiência de cárie (ceos=0), foi a ausência de visitas ao CD (Tabela 9), que à primeira vista parece incompreensível. No entanto, o que se observa, sobretudo em populações de baixo NSE, como a maioria das crianças desta amostra, é que a procura ao CD só ocorre, quando existem problemas dentários que geram dor ou desconforto (VASCONCELOS et al, 1994; MARTINS, ARAÚJO, VELOSO, 1999; KRAMER et al, 2008), pois a grande maioria da população não tem adequada formação em saúde bucal (MARTINS, ARAÚJO, VELOSO, 1999). Além deste aspecto, ressalta-se que populações de baixo NES também têm dificuldades no acesso a bens e serviços públicos de saúde que 
prestam atendimento preventivo. (MAIA et al, 2007; GRADELLA et al, 2007). A busca por atendimento odontológico aumenta também com a idade, porque também os problemas tornam-se mais prevalentes. (VASCONCELOS et al, 1994; MARTINS, ARAÚJO, VELOSO, 1999; KRAMER et al, 2008).

A fim de avaliar todos os fatores indicadores do risco de cárie conjuntamente e identificar aqueles que mais influenciassem a experiência de CPI foi realizada uma análise de regressão linear múltipla, que avalia diferentes variáveis independentes simultaneamente, com uma variável dependente, ou a CPI. Os resultados dessa análise podem ser conferidos na Tabela 10, que expressa os valores dos coeficientes e níveis descritivos obtidos. Por essa análise, quando o fator B for positivo, ele expressa uma variação no mesmo sentido, ou seja, há a chance de ocorrência da CPI, sempre que a variável estiver presente. Quando o valor de B for negativo, ele expressa uma variação em sentido contrário, ou seja, não há a chance de ocorrência de CPI, quando a variável estiver presente.

Pode-se observar que de todos os indicadores de risco estudados, encontrou-se significância apenas para cinco deles. Quanto ao gênero, da mesma forma que na análise individual, destacou-se o masculino, como já descrito anteriormente. A freqüência de escovação apresentou um valor de B negativo , indicando que que quanto maior fosse a freqüência de escovação menor seria a ocorrência de CPI. Muitos trabalhos contrariam esses dados, mostrando resultados conflitantes com relação a este fator, indicando um efeito negativo da maior freqüência de escovação. (REISINE, LITT, TINANOFF, 1994; SANTOS et al, 1997; SILVA et al, 2006; MAIA et al, 2007). Esses resultados, normalmente são explicados pela deficiência da escovação, que normalmente é realizada somente pela criança, como neste estudo, e, portanto, com um grau de higiene bucal deficiente. Aliás, este também foi um aspecto observado neste estudo, em que pelo menos $57 \%$ das crianças da amostra apresentavam biofilme visível. Contudo, não é simples a explicação para esse tipo de achado. Talvez um questionamento mais profundo com os pais sobre os hábitos de escovação de seus filhos, pois também é provável, que eles tenham superestimado a freqüência de escovação das crianças, ou ainda aquelas com maior número de lesões, tenham sido advertidas a realizar uma escovação mais freqüente. (REISINE, LITT, TINANOFF, 1994). A escovação bem realizada, no entanto, é sem dúvida um fator positivo no controle da CPI . (REISINE, 
PSOTER, 2001; TOASSI, PETRRY, 2002; STECKSEN-BLICKS, SUNNEGARDH, BORSSEN, 2004;; VASCONCELOS et al, 2004; MAIA et al, 2007). Ao se realizar mais que uma escovação diária há sem dúvida, maior chance de se atingir áreas não alcançadas com uma única escovação. Além disso, essas escovações múltiplas, têm também uma melhor chance de neutralizar ataques ácidos produzidos pelas refeições diárias feitas pela criança, havendo portanto como resultado final, um maior benefício na prevenção da CPI, para essas crianças. Por outro lado, várias escovações diárias mal executadas não reverteriam em um benefício preventivo significante ao indivíduo.

Para a freqüência do uso do fio dental, o valor de $B$ foi positivo indicando que quanto maior ela fosse, maior seria a ocorrência de CPI. Esse resultado pode ser interpretado pelo fato de, em primeiro lugar, uma informação superestimada, dada pelos pais, uma vez que, embora muitas mães afirmem que seu uso é importante na prevenção da cárie em seus filhos (THEODORO et al, 2007) elas também afirmam que seus filhos não o utilizam (SORAGGl et al, 2007; PAREDES et al, 2009) além do fato, de uma criança até os 6 anos de idade não conseguir em sua maioria, usálo corretamente.

Para a presença de fumante na residência, o sinal de B foi negativo, indicando que quanto maior o número de fumantes, menor seria a ocorrência de CPI. Esse dado contradiz outros autores (WILLIAMS, KWAN, PARSONS, 2000; ALIGNE et al, 2003; SHENKIN et al, 2004; IIDA et al, 2009). Ainda não se sabe ao certo se a fumaça do cigarro da mãe, associa-se com maior risco de cárie, pela presença de elevados níveis séricos de cotinina em crianças que são fumantes passivos, ou se esta substância apenas serve de marcador para uma causa real e não mensurável da cárie, como o fato da mãe que fuma, apresentar uma tendência a fazer escolhas não saudáveis de dieta e hábitos de higiene bucal. (ALIGNE et al, 2003; SHENKIN et al, 2004; IIDA et al, 2009).

Para o NSE (baixo), o sinal de $B$ foi negativo, indicando que quanto menor o NSE, maior seria a ocorrência de CPI. Este tipo de relação tem sido relatado por inúmeros autores nacionais e internacionais. (SCHOU, UINTENBROEK, 1995, FREIRE et al, 1996; FREIRE et al, 1999; HALLET, O'ROURKE, 2003; THEODORO et al, 2007; MENEGHIM et al, 2007; DUMITRACHE, SFEATCU, BUZEA, 2008). 
Uma situação inversa é encontrada em sociedades africanas (ADEKOYASOFOWORA et al, 2006). As famílias de baixo NSE convivem com inúmeras dificuldades, como o acesso a serviços de saúde, educação e ofertas de trabalho. Por essas razões essas famílias, em piores condições sociais têm maiores dificuldades de enfrentar seus problemas de saúde, porque simplesmente elas não conseguem vencer as barreiras sociais e econômicas que lhes deram origem. Portanto, em muitas sociedades são necessárias profundas mudanças socioeconômicas para reverter o quadro social vigente. (SILVEIRA, BRUM, SILVA, 2002). O modelo matemático empregado apresentou uma significância de $p=0,000$. Isto significa que ele teve lógica, não ocorrendo aleatoriamente. $O \mathrm{R}^{2}$ indica que houve correlação entre as variáveis independentes e a variável dependente e, que $26 \%$ das variações na ocorrência da CPI, podem ser explicadas por este modelo matemático.

\section{Amosta parcial (37 a 71 meses):Índice de Saúde Bucal - ceos}

No presente estudo, a distribuição da prevalência de CPI, de acordo com os grupos: sem CPI; com CPI somente anterior; somente posterior e, $\mathrm{CPI}$ anterior e posterior, demonstram uma maior prevalência do grupo com CPI posterior, comparado com os demais grupos que apresentavam $\mathrm{CPI}$. No entanto o grupo mais prevalente foi o de crianças sem CPI, revelando também nesta amostra parcial, que foi evidenciada a polarização da CPI (Tabela 11). Isso denota baixa prevalência de CPI nesta população estudada (26,98\%).

A importância de se analisar a prevalência de CPI considerando-se a região da boca, é que existem evidências de que a criança que tem o padrão de cárie anterior superior, tem maior número de lesões posteriores e, de forma significante. (O' SULLIVAN, TINANOFF, 1993). De acordo com esses autores, as crianças que apresentam cárie na região anterior são de grande risco para desenvolvimento de CPI na região posterior devido ao nível aumentado de $\mathrm{S}$. mutans associado à $\mathrm{CPI}$ anterior. Assim, o ceos de crianças de 3 a 5 anos de idade, que apresentassem um padrão de CPI anterior superior + posterior, seria maior que o ceos posterior, de 
crianças que apresentavam somente o padrão posterior de CPI. E, o ceos posterior de crianças que apresentavam o padrão de CPI anterior superior + posterior, também seria maior que o ceos posterior de crianças que apresentavam somente 0 padrão posterior de CPI (O' SULLIVAN, TINANOFF, 1993).

Neste trabalho, o valor encontrado para o ceos $P$ do grupo que apresenta CPI $A+P$ foi de 0,051 , menor do que o ceos $P$ do grupo que só apresentava cárie $P$ (ceos=0,45). Este resultado foi significante pela análise do teste de Mann-Wintney $(p=0,005)$, porém contraria os obtidos no estudo de O'Sullivan, Tinanoff (1993), em que o ceos $\mathrm{P}$ do grupo com $\mathrm{CPI} \mathrm{P}+\mathrm{A}$ foi de 2,5 vezes maior que o ceos $\mathrm{P}$ do grupo que só apresentava CPI P. Além disso, quando se comparou o ceos total do grupo que apresentava $\mathrm{CPI} A+P($ ceos=0,49) ele foi praticamente igual do ceos do grupo que só apresentava CPI P (ceos=0,45). Novamente este trabalho contraria os obtidos por O'Sullivan, Tinanoff (1993) em que se obteve um valor de ceos total $(A+P) 5,1$ vezes maior que o observado no grupo de crianças que só apresentaram CPI P.

Considerando-se a prevalência de CPI nesta amostra parcial, o grupo com padrão de $\mathrm{CPI}(\mathrm{A}+\mathrm{P})$, apresentou uma prevalência de $\mathrm{CPI} P 13$ vezes menor que 0 grupo com padrão de CPI só $P$. Dois fatos podem ter contribuído para esses resultados contraditórios. O primeiro deles é que da amostra total, apenas $1,46 \%$ ou 5 crianças apresentaram CPI A+P (Tabela 11). O segundo, apenas 1,75\%, ou 6 crianças na amostra total, apresentaram CPI somente anterior. Portanto, de 341 crianças de 3 a 6 anos de idade que apresentaram o maior volume de cárie, apenas 11 crianças apresentaram CPI anterior. Portanto, para a amostra de 37 a 71 meses, dos dois municípios juntos de acordo com o índice de ceos, observou-se que não houve influência da experiência de CPI anterior na de CPI posterior encontrada. 
7 Conclusões 



\section{CONCLUSÕES}

Através da análise dos resultados encontrados neste estudo permitiu-se:

Constatações:

Análise Descritiva

- Prevalência de Cárie

$\checkmark$ Quanto à CPI, verificou-se uma distribuição não homogênea entre as crianças, com predomínio daquelas sem $\mathrm{CPI}$;

$\checkmark$ A prevalência de cárie por faixa etária foi baixa e aumentou com a idade, estando presente em idade bem precoce;

$\checkmark$ A maior prevalência de cárie foi observada na região posterior, com o pico entre os 37 e 48 meses de idade;

- Indicadores de Saúde Bucal: ceos, IPV e ISG

$\checkmark$ verificou-se que o ceos por faixa etária foi baixo, aumentou com a idade, com o maior valor entre 37 e 48 meses de idade

$\checkmark$ verificou-se que $57 \%$ das crianças apresentavam IPV, sendo sua distribuição homogênea nas diferentes faixas etárias;

$\checkmark$ não se verificou ISG em nenhuma criança da amostra;

\section{Análise Estatística}

$\checkmark$ verificou-se que tanto o ceos como o IPV foram maiores e significantes para as crianças do município de Areado, portanto este resultado rejeita parcialmente o primeiro item da primeira hipótese nula;

$\checkmark$ verificou-se que entre as instituições públicas e privadas não houve diferença estatisticamente significante quanto ao ceos e IPV dos dois municípios juntos e do ceos para o município de Areado isoladamente, portanto este resultado aceita o segundo item da primeira hipótese nula; 
$\checkmark$ verificou-se que entre as instituições com e sem assistência odontológica não houve diferença estatisticamente significante quanto ao ceos dos dois municípios juntos e do ceos e IPV para o município de Alfenas isoladamente, portanto este resultado aceita parcialmente o terceiro item da primeira hipótese nula;

$\checkmark$ verificou-se que dos fatores indicadores de risco estudados isoladamente, somente o gênero masculino $e$ as visitas ao $C D$ foram relacionados significantemente com a experiência de CPI, portanto este resultado aceita parcialmente a segunda hipótese nula;

$\checkmark$ verificou-se que dos fatores indicadores de risco estudados em conjunto, 0 gênero masculino, a freqüência de escovação, uso do fio dental, presença de fumante na residência e nível socioeconômico foram relacionados significantemente com a experiência de $\mathrm{CPI}$, portanto este resultado aceita parcialmente a segunda hipótese nula e,

$\checkmark$ verificou-se uma relação inversa e significante ao esperado, com o padrão de CPI somente posterior, prevalecendo sobre quem apresentava o padrão anterior + posterior, portanto este resultado aceita a terceira hipótese nula.

\section{Conclusão}

A amostra de pré-escolares estudada revelou que a CPI afeta essa população de forma polarizada, numa idade muito precoce, com ênfase nos dentes posteriores, os quais necessitam de uma proteção precoce e específica para eles. O nível de acúmulo de biofilme visível é elevado em todas as faixas etárias e não correspondeu à história de $\mathrm{CPI}$, relativamente baixa nesta população; e nem ao bom nível de saúde gengival. No entanto, requer uma atenção preventiva profissional e dos pais/responsáveis, para controle deste biofilme e, de seus efeitos nocivos à saúde bucal. Isto foi demonstrado de forma significante, pelo efeito positivo da atenção odontológica verificada entre os municípios estudados. 
Referências 



\section{REFERÊNCIAS}

ABDO, R. C. C.; NUNES; D. N.; SALLES, V. Revisão de literatura, cárie rampante, etiologia e soluções de tratamento. R Univ Alfenas, Alfenas, v. 4, p. 159-163, p 1 10. 1998.

ADEKOYA-SOFOWORA, C.; NASSIR, W. O.; TAIWO, M.; ADESINA, O. A. Caries experience in the primary dentition of nursery school children in Ife, Ife, Nigéria.

African Journal of Oral Helth, Nigéria, v.2, n. 1, p. 19-25. 2006.

AINAMO, J.; BAY, I. Problems and proposals for recording gingivitis and plaque. Int Dent J, Inglaterra, v. 25, n. 4, p. 229-235, Dec. 1975.

ALALUUSUA S., MALMIVIRTA, R. Early plaque accumulation-a sign for caries risk in young clhildren. Community Dent Oral Epidemiol, Dinamarca, v. 22, n. 5 (Part 1), p. 273-276, Oct. 1994.

AL-BANYAN, R. A. et al. Oral health survey of 5-12-year-old children of national guard employees in Riyadh, Saudi Arabia. J Paediatric Dentistry, Inglaterra, v. 10, p. 39-45. 2000

ALIGNE, C. A. et al. Association of pediatric dental caries with passive smoking. $\mathbf{J}$ AM Dent Assoc, Estados Unidos, v. 289, n. 10, p. 1258- 1264. 2003.

AMERICAN ACADEMY OF PEDIATRIC DENTISTRY. Policy on early childhood caries (ECC): Classifications, consequences and preventive strategies. Pediatr Dent, Estados Unidos, v. 30, n. 7, (Reference Manual), p.40-43, 2008-2009.

AMERICAN ACADEMY OF PEDIATRIC DENTISTRY. Policy on use of caries-risk assessment toll (CAT) for infants, children, and adolescents. Pediatr Dent, Estados Unidos, v. 28, n. 7, (Reference Manual), p. 24-28, 2007.

ANDERSON, M. Risk assentment ande epidemiology of dental caries: reviieiw of the literature. Pediatric Dent, Estados Unidos, v. 5, n. 24, p. 377-385, Sept-Oct. 2002.

ANTUNES, L. F.; PERES, M. A.; MELLO, T. R. C. Determinantes individuais e contextuais da necessidade de tratamento odontológico na dentição decíddua no Brasil. Ciênc Saúde Coletiva, Rio de Janeiro, v. 11, p. 79-87. 2006.

ARAI, P. S.; CAMARGO, A. L. R.; JORGE, A. O. C.; REGO, M. A. Avaliação do risco de cárie em crianças através de método convencional e do programa cariograma. JBP, Curitiba, v. 6, n. 32, p. 317- 324, 2003. 
ARNLAUGSSON S.; MAGNUSSON T. E. Prevalence of gingivitis in 6-year-olds in Reykjavik, Iceland. Acta Odontol Scand, Scandinávia, v. 54, p. 247-250. 1996.

AZEVEDO, T. D. P. L.; BEZERRA, A. C. B.; TOLEDO, O. A. feedind habits and severe early childhood caries in brazilian preschool children. Pediatr Dent, Estados Unidos, v. 27, n.1, p. 28-33. 2005.

BARBER L. R.; WILKINS, B. S. Evidence-based prevention, management, and monitoring of dental caries. The Journal of dental Hygiene, v. 76, n. 4. 2002.

BARBOSA A. P. C.; KRINGER, L.; MOYSÉS, S. T.; MOYSÉS, S. J. Prevalência da doença cárie em crianças de cinco anos de idade na cidade de Curitiba: análise crítica. Epidemiol Serv Saúde, Brasília, v. 16, n. 2, Jun. 2007.

BARROS, S. G. de et al. Contribuição ao estudo da cárie dentária em crianças de 0 a 30 meses. Pesqui Odontol Bras, São Paulo, v. 15, n. 3, p. 215-222, Jul-Set. 2001.

BASTOS, J. R. M.; MAGALHÃES, S. A.; SILVA, R. H. A. Levantamento Epidemiológico de Cárie Dentária no Município de Poço Fundo, Minas Gerais, nos anos de 1999 e 2003. Arquivos em Odontologia, Belo Horizonte, v. 42, n. 2, p. 81160, Abr-Jun. 2006.

BECK J D. Risk revisited. Community Dent Oral Epidemiol, Dinamarca,v. 26, p.220-225.1998.

BENEDETTO, M. S. de. et al. Correlação epidemiológica de prevalência e necesidade de tratamento de cárie dentária entre mães e bebês de 6 a 24 meses de idade em São Paulo. JBP, Curitiba, v. 2, n. 9, p. 357-361. 1999.

BOLIN A. K.; BOLIN, A.; JANSSONL; CALLTORP. Children's dental helth in Europe. Swed Dent J, Suécia, v. 21, p.25-40.1997.

BÖNECKER, M. J. S. et al. Redução na prevalência e severidade de cárie dentária em bebês. JBP, Curitiba, v. 3, n. 14, p.334-340. 2000.

BÖNECKER, M. J. S. Tendência da experiência de cárie dentária em crianças de 5- 59 meses de idade do município de Diadema (SP) entre os anos de 1995 e 2004. 2005. 107 f. Tese (Livre-Docente em Odontologia - Odontopediatria) Faculdade de Odontologia da Universidade de São Paulo, São Paulo. 2005. 
BÖNECKER, M. J. S.; GUEDES-PINTO, A. C.; WALTER, L. R. F. Prevalência, distribuição e grau de afeccção de cárie dentária em crianças d e 0 a 36 meses de idade. Rev Assoc Paul Cirur Dent, São Paulo, v. 5, n. 6, p. 535-540, Nov-Dez.. 1997.

BRANDÃO I. M. G et al. Cárie precoce: influências de variáveis sóciocomportamentais e do lócus de controle da saúde em um grupo de crianças de Araraquara, São Paulo, Brasil. Cad. Saúde. Publica, Rio de Janeiro, v. 22, n. 6, p. 1247-1256, Jun. 2006.

BRASIL. MINISTÉRIO DA SAÚDE. Projeto SB Brasil 2003. Condições de saúde bucal da população brasileira 2002 - 2003: resultados principais. Brasília, 2004. $68 \mathrm{p}$.

BROUDEUR, J-M.; GALARNEAU, C. The high incidence of early childdhood caries in Kindergarten-age children. J Ord Dent Quebec, Quebec, Suplement, Apr. 2006

BURT, A. B. Definitions of risc. J Dent Educ, Estados Unidos, v. 65, n. 10, p. 10071015. 2001.

CANGUSSU, MCT, COELHO, EO, FERNANDEZ, RAC. Epidemiologia e iniqüidade em saúde bucal aos 5, 12 e 15 anos de idade no município de Itatiba, São Paulo, 2000. Rev FOB, São Paulo, v.9,n.1/2, p. 77-85, Jan-Jun. 2001.

CARTER, H. G.; BARNES, G. P. The gingival bleeding index. J Periodontol, Estados Unidos, v. 45, n. 11, p. 801- 805, 1974.

CARVALHO, K. S. et al. Avaliação da prevalência de cárie em crianças de 0 a 6 anos nas cidades de Uberlândia e Araguari MG. Horizonte Científico, Uberlândia, v. $1,2002$.

CAUFIELD P, CUTTER G R, DASANAYAKE A P. Initial acquisition of mutans streptococci by infants: evidencr for a discrete window of infectivity. J Dent Res, Estaddos Unidos, v. 72, n. 1, p. 37-45, Jan. 1993.

CERQUEIRA, L. M.; ALVES, M. S.; BONECKER, M. J.; PINHO, A. L. Estudo da Prevalência de Cárie e da Dieta em Crianças de 0-36 meses na cidade de Natal, RN. JBP, Curitiba, v. 2, n. 9, p. 351-356, 1999.

COUTO, G. B. L. et al. Prevalência de cárie, mancha branca e placa visível em cças de 0 a 36 meses, assistidas pelo Programa de Saúde da Família na cidade de Camaragibe, PE. Odontol Clin Científ, Recife, v. 4, n. 1, p. 19-28, Jan/Abr., 2005. 
DAVENPORT, E. S. Caries in the preschool child: aetiology. J Dent, Inglaterra, v. 18, p. 300-303. 1990.

DAVIDOFF, D. C. O.; ABDO, R. C. C.; SILVA, S. M. B. Prevalência de cárie precoce da infância. Pesq Bras Odontoped Clin Integr, João Pessoa, v. 5, n. 3, p. 215-221, Set-Dez. 2005.

DECLERK, D. et al. Factors associated with prevalence and severity of caries experience in preschool children. Community Dent Oral Epidemiol, Dinamarca, v. 36, p. 168-178. 2008..

DEFINITION of Early Childhood Caries. Definition of of Early Childhood Caries. Pediatr Dent, Estados Unidos , v. 28, n. 7, p. 13, 2007.

DINI, E. L.; HOLT, R. D.; BEDI, R. Caries and its association with infant feeding and oral health-related behaviours in 3-4 year old Brazilian children. Community Dent Oral Epidemiol, Dinamarca, v. 28, p. 241-248, Aug. 2000.

DUMITRACHE, M. A.; SFEATCU, R.; BUZEA, C. Socio-economica and caries experience in primary teeth among schoolchildren of 1-st grade in Bucharest. OHDMBSC, Romênia, v.7, n.2, June. 2008.

FEITOSA, S.; COLARES, V. Prevalência de cárie dentária em pré-escolares da rede pública de Recife, Pernambuco, Brasil, aos quatro anos de idade. Cad Saúde Pública, Rio de janeiro, v.20, n. 2, p. 604-609, Mar-Abr, 2004.

FELDENS, E. G.; KRAMER, P. F.; FELDENS, C. A.; FEREIRA, S. H. Distribution of plaque and gingivitis and associated factors in 3-to 5-year-old brazilian children. $\mathbf{J}$ Dent Child, Estados Unidos, v. 73, n. 1, p. 4- 10, 2006.

FREIRE, M. C. M. et al. Experiência de cárie em crianças de instituições de educação infantil com e sem assistência odontológica. Rev Odonto Ciênc, Rio Grande do Sul, v. 24, n. 1, p. 64-70. 2009.

FREIRE, M. C. M.; MELO, R. B.; SILVA, S. A. Dental caries prevalence in relation to socioeconomic status of nursery school children in Goiânia - GO, Brazil.

Community Dent Oral Epidemiol, Dinamarca, v. 24, n. 5, p. 357-361, Oct. 1996.

FREIRE, M. C. M.; NUNES, M. F.; SOARES, F. F. Fatores relacionados à saúde bucal em creches de Goiânia-GO. Odontologia e Sociedade, Goiânia, v. 9, n. 11, p. 1-6. 2007. 
FRITSCHER, A. M. G., ARAÚJO, D. F.; FIGUEIREDO, M. C. Avaliação comparativa dos pindices de cárie, placa visível e sangramento gengival de 50 pares mãe-filho. JBP, Curitiba, v. 1, n. 4, p. 34-42. 1999.

GALGUT, P. A comparison of different indices used in the clinical assessment of plaque and gingival bleeding. Clin Oral Invest, Londres, v. 3, p. 96-99, 1999.

GOMES P. R.; COSTA, S.C.; CYPRIANO, S.; SOUSA, M. L.R. Paulínia, São Paulo, Brasil: situação da cárie dentária com relação ás metas OMS 2000 e 2010. Cad.

Saúde Pub, Rio de Janeiro, v. 20, n. 3, p. 866-870, Mai-Jun. 2004.

GOMES-FILHO, I. S. et al. Relationship among gender, race, age, gingival width, and probing depth in primary teeth. J Periodontol, Estados Unidos, v. 77, n. 6. p. 1032-1042. 2006

GRACIANO, M. I. G. Critérios de avaliação para classificação sócio-econômica. Serv Social Soc, São Paulo, v.1, n. 3, p.181-193. 1980.

GRADELLA, C. M. F. et al. Epidemiologia da cárie dentária em crianças de 5 a 59 meses de idade no município de Macapá, AP. RGO, Porto Alegre, v. 55, n. 4, p. 329334, Out.-Dez, 2007.

GUEIROS, L. A. M.; SILVA, M. D. P. Da. Inquérito de cárie e perfil alimentar em escolas de 6 a 12 anos de duas populações da região metroplolitana do Recife. Odontol Clin Cientif, Recife, v.2, n. 3, p. 201-209, Sep-Dez. 2008.

GUSSY, M. G. et al. Early childhood caries: current evidence for aetiology and prevention. Journal of Paediatric and child Health, Australia, v. 42, p. 37-43. 2006.

HALLET, K. B.; O' ROURKE, P. K. Early childhood caries an infant feeding pratice. Community Dent Health, Inglaterra, v. 19, n., p. 237-242. 2002

HALLET, K. B.; O' ROURKE, P. K. Social and behavioural determinants of early childhood caries. Aust Dent J, Austrália, v. 48, n. 1, p. 27-33, 2003.

HELDERMAN P.; SOE, W.; HOF, M. A. Risk fators of early childhood caries in a Southeast Asian population. J Dent Res, Estados Unidos, v. 85, n. 1. 2006.

HOFFMANN R. H. S. et al. Experiência de cárie dentária em crianças de escolas públicas e privadas de um município com água fluoretada. Cad Saúde Pub, Rio de Janeiro, v. 20, n. 2, p. 522-528, Mar-Abr. 2004. 
HOLST, A.; MARTENSSON, I.; LAURIN, M. Identification of caries risk children and prevention of caries in pre-school children. Swed Dent J, Suécia, v. 21, p. 185-19, 1997.

IIDA, $\mathrm{H}$. et al. Association between infant breastfeeding and early childhood caries in the United States. Pediatr. Dent, Estados Unidos, v. 120, n. 4, p. 944-952. 2009..

IRIGOYEN M. E et al. Caries experience and treatment nees in 6-12 year-old urban population in relation to scioeconomic status. Community Dent Health, Inglaterra, v. 13, n. 2, p. 96-98, Jun. 2002.

KIWANUKA, S. N.; ASTROM, A. N.; TROVIK, Dental caries experience and its relationship to social and behavioural factors among 3-5-year-old chlidren in Uganda. Int J Paediatric Dentistry, Inglaterra, v. 14, p. 336-346. 2004.

KRAMER, P. F. et al. Utilização de serviços odontológicos por crianças de 0 a 5 anos de idade no Município de Canela, Rio Grande do Sul, Brasil. Cad Saúde Pública, Rio de Janeiro v.24, n.1. 2008.

LEITE F. R. M. et al. Avaliação das condições bucais das crianças de cinco e seis anos em duas creches de Belo Horizonte. Pesq Bras Odontop Clin Integr, João Pessoa, v.4, n.3, p.205-210, Set-Dez. 2004.

LEITE, T. A. et al. Cárie dental e consumo de açúcar em crianças assistidas por creche pública. Rev Odontol Univ São Paulo, São Paulo, v. 13, n. 1, p. 13-18. 1999.

LEROY R, BOGAERTS K, LESAFFRE E, DECERCK D. - Effect of caries experience in primary molars on cavity formation in the adjacent permanent first molar. Carie Res, Suíça, v. 39, p. 342-349. 2005.

LEVERETT, D. H. et al. Caries risk assessment by a cross-sectional discrimation model. J Dent Res, Estados Unidos, v. 72, n. 2, p.529-537, Feb. 1993.

LITT, M. D.; REISINE, S.; TINANOFF, N. Multidimesinonal causal model of dental caries development in low-icome preschool children. Public Health Rep, Estados Unidos, v. 110, n. 5, p. 607-617, Sep-Oct. 1995.

LOE, H.; SWITZERLAND, B. Oral hygiene in the prevention of caries and periodontol disease. Int Dent J, Inglaterra, v. 50, p. 129-139. 2000. 
LOMBARDI, C. et al. Operacionalização do conceito de classe social em estudos epidemiológicos. Rev. Saúde Pública, São Paulo, v. 22, n. 4. p. 253-265. 1988.

LUCA, R.; MUNTEANU, A.; FARCASIU, C. Severe early childhood caries in a group of preschool children over a two year period. OHDMBSC, Romênia, v. 7, n. 3, p. 913, Sept, 2008.

LULIC-DUKIC et al. Factors predisposing to early clhildhood caries (ECC) in clhidren of pre-school age in the city of Zagreb, Croatia. Coll Antropoll, Croacia, v. 1, p. 297302.

MACIEL, S. S. V. V. et al. Prevalência da cárie precoce na infância em crianças de 0-36 messes em creches públicas de Caruaru/PE. Pesq Bras Odontoped Clin Integr, João Pessoa, v. 7, n.1, p-59-65, Jan-Abr. 2007.

MAIA, S. A, et al. Prevalência de cárie em crianças de 0 a 60 meses, na cidade de Manaus. Conscientiae Saúde, São Paulo, v. 6, n. 2, p. 255-258. 2007,

MARSHALL T. A. et al. The roles of meal, snack, and daily total food and beverage exposures on caries experience in young children. Jornal of Public Health

Dentistry, v. 65, p.166-73. 2005.

MARTINS, M. D.; ARAÚJO, R. G. D.; VELOSO, N. F. Avaliação das necessidades de tratamento odontológico de crianças de baixa renda. JBP, Curitiba, v.2, n.6. 1999.

MARTINS, R. J. et al. Declínio da cárie em um município da região noroeste do Estado de São Paulo, Brasil, no período de 1998 a 2004. Cad Saúde Pública, Rio de Janeiro, v. 22, n. 5, p. 1035-1041, Mai. 2006.

MATTOS-GRANER, R. O. et al. Caries prevalence in 6-36 month-old Brazilian children. Community Dent Health, Inglaterra, v. 13, n. 2, p. 96-98, Jun. 1998.

MEDEIROS, U. V.; SOUZA, M. I. C.; FONSECA, C. T. Prevalência de cáries em pacientes bebês. JBP, Curitiba, v. 1, n. 3, p.23-34, 1998.

MELO, M. M. D. et al. Polarização da cárie dentária em pré-escolares cadastrados no Programa saúde da Família do Recife. Odontol Clin Cientif, Recife, v. 8, n. 1, p. 35-40. 2009. 
MENEGHIM, M. C. et al. Classificação sócio-econômica e sua discussão em relação à prevalência de cárie e fluorose dentária. Ciênc Saúde Coletiva, Rio de Janeiro, v. 12, n. 2, p. 523-529, 2007.

MOREIRA, T. P.; NATIONS, M.K.; ALVES, M. S. C. F. Dentes da desigualdade: marcas bucais da experiência vivida na pobreza pela comunidade do Dendê, Fortaleza, Ceará, Brasil. Cad Saúde Pública, Rio de Janeiro, v. 23, n. 6, p. 1-10, Jan-Jun. 2007.

MOURA, L. F. A. D. et al. Avaliação da saúde gengival em crianças que frequentaram o programa preventive para gestantes e bebês na cidade de Teresina. RGO, Porto Alegre, v. 57, n. 1, p. 47-53, Jan./Mar., 2009.

NAKAMURA A. A. Erupção de dentes decíduos e cárie precoce da infância: estudo longitudinal. 2009. $191 \mathrm{f}$. Tese (Doutorado em Odontologia Odontopediatria) Faculdade de Odontologia de Bauru, Universidade de São Paulo, Bauru, 2009.

NARVAI, P. C;. CATEKLIANOS R. A.; FRAZÃO, P. Prevalência de cárie em dentes permanentes de escolares no Município de São Paulo, SP, 1970-1996. Rev Saúde Publica, São Paulo, v. 34, p. 196-200. 2000.

O'SULLIVAN, D. M.; TINANOFF, N. Maxillary anterior caries associated with increased caries risk in other primary teeth. J Dent Res, Estados Unidos v. 72, n. 12, p. 1577-1580, 1993b.

O'SULLIVAN, D. M.; TINANOFF, N. Social and biological factors contributing to caries of the maxillary anterior teeth. Pediatr. Dent, Estados Unidos, v. 15, n. 1, p. 41-44, Jan./Feb. 1993a.

O'SULLIVAN, D. M.; TINANOFF, N. The association of early dental caries patterns with caries incidence in preschool children. J Public Health Dent, Estados Unidos, v. 56, n. 2, p.81-83, 1996.

OLIVEIRA T. M. et al. Comparação entre índices ceos e ceos modificado em bebês e pré-escolares. Rev Odontol Univ São Paulo, São Paulo, v. 20, n. 2, p. 128-133. 2008.

ORGANIZAÇÃO MUNDIAL DE SAÚDE. Levantamento epidemiológico básico de saúde bucal: manual de instruções. 3 ed. São Paulo: Livraria Editora Santos. 1991. 
PAREDES. S. O. et al. Behavioral and social factors related to dental caries in 3 to 13 year-old children from João Pessoa, Paraíba, Brazil. Rev Odonto Ciênc, Rio Grande do Sul, v. 24, n. 3, p. 231-235. 2009.

PASAREANU, M. A. Considerations regarding early childhood caries. J Prev Med, Romênia, v. 15, p. 130-133. 2007.

PEREIRA, A. C.Odontologia em Saúde Coletiva. Porto Alegre: Artmed, 2003. p.83.

PETERSEN, P. E. Sociobehavioural risk factors in dental caries - international perspectives. Community Dent Oral Epidemiol, Dinamarca, v.33, p. 274279. 2005.

PIENIHAKKINEN, K.; JOKELA, J.; ALANEN, P. Assessment of caries risk in preschool children. Caries Res, Suíça, v. 38, p. 156-162, 2004.

PIGOZZO, M. N. et al. A importância dos pindices de pesquisa clínica odontológica: uma revisão da literatura. Rev Odontol da Univ Cidade de São Paulo, São Paulo, v. 20 , n. 3, p. 280-287. 2008.

PINTO. V. G. Saúde Bucal Coletiva. São Paulo: Santos. 2008

POLETTO, L. T. A. Levantamento epidemiológico e saúde bucal da população urbana de Bauru. 1993. Tese (Doutorado em Odontologia) Faculdade de Odontologia de Bauru - Universidade de São Paulo, São Paulo. 1993.

POLICY on tobacco use. Policy on tobacco uso. Pediatr Dent, Estados Unidos, v. 28, n. 7 , p. $45-46,2007$.

QIN, M.; LI, J.; ZHANG, S.; MA, W. Risk factors for severe early childhood caries in children younger than 4 years old in Beijing, China. Pediatr. Dent, Estados Unidos, v. 30, n. 2, p. 122-128, Mar./Apr. 2008.

REISINE, S. T.; PSOTER, WALTER. Socioeconomic status and selected behavioral determinants as risk factors for dental. Caries. J Dent Educ, Estados Unidos, v. 65, p.1009-1016. 2001

REISINE, S.; LITT, M.; TINANOFF, N. A biopsychosocial model to predict caries in preschool children. Pediatr. Dent., v. 16, n. 6, nov/dec.1994.

RIBEIRO, A. G.; OLIVEIRA, A. F. de; ROSENBLATT, A. Cárie precoce na infância:prevalência e fatores de risco em pré-escolares, aos 48 jmeses, na cidade 
de João Pessoa, Paraíba, Brasil. Cad Saúde Pública, Rio de Janeiro, v. 21, n. 6, p. 1695-1700, Nov-Dez. 2006.

RIPA, L. W. Nursing caries: a comprehensive review. Pediatr Dent, Estados Unidos, v. 10, n. 4 , p. 268-282, Dec. 1988.

ROBKE, F. J. Effects of nursing bottle misuse on oral health. J Orofac Orthop, Germânia, n. 1, p. 5-19. 2008

SANTOS A. P. P. et al. Oral hygiene frequency and presence of visible biofilm in the primary dentition. Braz Oral Res, São Paulo, v. 21, n. 1, p. 64-69. 2007.

SANTOS, A. P. P. dos; SOVIERO. V. M. Avaliação da qualidade da higiene bucal em lactentes e pré-escoalres: importância e método: revisão de literatura. Pesqui Odontol Bras, Curitiba v. 4, n. 2, p. 87-92, Mai-Ago. 2008.

SANTOS, C. S. dos et al. Avaliação de um programa educativo-preventivo periodontal em crianças de 6 a 8 anos de uma escola de rede pública de Porto Velho - RO. Odontol Clin Cientif, Recife, v.7, n. 3, p. 221-225. 2008.

SANTOS, M. F. dos et al. Relação entre doença cárie e gengivite e condições socioeconômicas dos usuários da creche comunitária centro infantil Murialdo.

Boletim da Saúde, Porto Alegre, v.18, n.1, Jan-Jn. 2004.

SARTORI, L. A. Prevalência da doença cárie em escolares de 5 a 14 anos, na cidade de Alfenas, MG. R Univ Alfenas, Alfenas, v. 5, p 1-10. 1999.

SCAVUZZI A. I. F. et al. Avaliação da Presença da Placa Visível e ICNTP em crianças de 3 a 5 anos na cidade de Feira de Santana-BA. JBP, Curitiba, v. 4, n. 20, Jul-Ago. 2001.

SCAVUZZI, A. I. F. Et al. Longittudinal study od dental caries in Brazilian children aged from 12 to 30 months. Int J Paediatr Den, Inglaterra, v. 17, p.123-128. 2007.

SCHOU L.; UITENBROEK, D. Social and behavioural indicators of caries experience in 5-years-old children. Community Dent Oral Epidemiol, Dinamarca, v.23, n.5, 276-81. 1995.

SERRATINE, A. C. P. et al. Prevalência de cárie dental em crianças de 19 a 31 meses de idade, matriculadas em creches públicas e particulares em Itajaí, SC. JBP, Curitiba, v. 6, n. 32, p. 311- 315. 2003. 
SHEIHAM, A. Impact of dental treatment on the incidence of ddental caries in chiçdren and adults. Community Dent Oral Epidemiol, Dinamarca, v.25, 104-112. 1996

SHENKIN, J. D. Et al. The association between uviromental tobacco smoke tooth caries. J Public Health Dent, Estados Unidos, v. 3, p. 184-186. 2004.

SILVA, J. S. et al. Prevalência de cárie e indicadores de risco em crianças de 2 a 6 anos na clínica de odontologia preventiva - UFPB. Rev Odonto Ciência, Rio Grande do Sul, v.21, n. 51, p. 17-21. 2006.

SILVA, S. M. B.; Oliveira, F. S.; Pereira Júnior, E. S.; Machado, M. A. A. M. Cárie precoce na infância: relato de caso clínico. JBP, Curitiba, v.4, n.22, Nov-Dez. 2001.

SILVEIRA, J. L. G. C.; OLIVEIRA, V.; PADILHA, W. W. N. Avaliação da redução do índice de placa visível e do índice de sangramento gengival em uma prática de promoção de saúde bucal com crianças. Pesqui Odontol Bras, São Paulo, v. 16, n. 2, p. 169-174, 2002.

SILVEIRA, R. G.; BRUM, S. C.; SILVA, D. C. Influência dos fatores sociais, educacionais e econômicos na saúde bucal das crianças. RMAB, Rio de janeiro, v.52, n.1/2, Jan-Dez. 2002.

SIMRATVIR, M. et al. Evaluataion of caries experience in 3-6-year-old children, and dental attitudes amongst the caregivers in the Ludhiana city. J Indian soc Pedod Prevent Dent, India, v. 27, n. 3, p. 164-169, Jul-Sept. 2009.

SLADE, G. D. et al. Intra-oral distribution and impact of caries experience among South Australian school children. Austr Dent. J, Austrália, v. 41, n. 5, p. 343350.1996.

SLADE, G. D. et al. Intra-oral distribution andd impact of caries experience among South Australian scjool children. Australian Dental Journal, Australia, v. 41, n. 5, p. 343-350. 1996.

SORAGGI, M. B. S. et al. A cárie dentária e suas condicionantes em crianças de uma escola pública municipal em Niterói, RJ. Pesq Bras Odontoped Clin Integr, João Pessoa, v. 7, n. . 2, p. 119-124, Mai-Ago. 2007.

STECKSEN-BLICKS, C.; SUNNEGARDH, K.; BORSSÉN, E. Caries experience and background factors in 4-year-old children: time trends 1967-2002. Caries Res, Suíça, v. 38 , p. $149-155$. 
THEODORO, D. S. et al. Fator socioeconômico e o grau de conhecimento das mães em relação à saúde bucal de bebês. Odontol Clin Cientif, Recife, v. 6, n. 2, p.133137. 2007.

TINANOFF, N.; KANELLIS, M. J.; VARGAS, C. M. Current understanding of epidemiology, mechanisms, and prevention of dental caries in preschool children.

Pediat. Dent, Estados Unidos, v. 24, n. 6, p. 543-551, 2002.

TINOCO, N. M. B.; GJERMO P. Comparison of the effectiveness of three different methods in detection of changes in gingivitis in the primary dentition. Community Dent Oral Epidemiol, Dinamarca, v.20, p. 84-86. 1992.

TOASSI, R.F.C.; PETRY, P.C. Motivação no controle do biofilme dental e sangramento gengival em escolares. Rev Saúde Pública, São Paulo, v. 36, n. 5, p. 634-637, 2002.

TOMITA, N. E et al. Prevalência de cárie dentária em crianças da faixa etária de 0 a 6 anos matriculadas em creches: importância de fatores socieconômicos. Rev

Saúde Publica, São Paulo, v. 30, n. 5, p. 413-420, out. 1996.

TRAEBERT J. L. et al. Prevalência e severidade da cárie dentária em escolares de seis a doze anos de idade. Rev Saúde Publica, São Paulo, v. 35, p. 283-288. 2001.

TREATING caries as an infectious disease. Treating caries as an infectious disease. J Am Dent Assoc, Estados Unidos, v.126, Jun. 1995.

VAN PALESTEIN HELDERMAN, W. H.; SOE, W.; Van't Hof, M. A. Risk factors of early childhood caries in a Southeast Asian population. J Dent Res, Estados Unidos, v. 85 , n. 1 , p. 85-88. 2006.

VASCONCELOS, M. et al. Avaliação e promoção de saúde bucal de crianças entre 5 e 6 anos da Creche Sagrado Coração de Jesus. Anais do $7^{\circ}$ Encontro de

Extensão da Universidade Federal de Minas Gerais, Belo Horizonte. 2004.

VICENTE, V. A. et al. Relação entre a prevalência da doença cárie e risco microbiológico. Cienc Odontol Bras, Curitiba, v.11, n. 2, p. 44-48. 2008.

VOLPATO, L. E. R.; FIGUEIREDO, A. F. de. Estudo da clientela do programa atendimento odontológico precoce em um serviço público do município de Cuiabá, Mato Grosso. Rev Bras Saúde Materna Infantil, Recife, v. 5, n. 1, p. 49-52, JunMar. 2005. 
VOLSCHAN, B. C. G.; SOARES, E. L. Cárie de estabelecimento precoce: relação entre o biológico e o psicossocial. JBP, Curitiba, v. 6, n. 34, p. 533- 540, 2003.

WALTER, L. R. F.; NAKAMA, R. Prevenção da cárie dentária através da identificação, determinação e controle dos fatores de risco em bebês - parte 1. JBP, Curitiba, v. 1, n. 3, p. 91-100. 1998.

WARREN, J. J. et al. A longitudinal study of dental caries risk among very young low SES children. J Public Health Dent, Estados Unidos, v.37, n.2, p. 116-122. 2009.

WARREN, J. J.; LEVY, S. M.; KANELLIS, M. J. Dental caries in the primary dentition: assessing prevalence of cavitated and noncavitated lesions. J Public Health Dent, Estados Unidos, v. 62, n. 2, p. 109-114. 2002.

WENDT L. K. et al.Infants and toddlers with caries. Swed Dent J, Suécia, v. 19, p. 17-27. 1995

WENNHALL, I. et al. Caries preventive effect of an oral health program for preschool children in a low socio-economic, multicultural area in Sweden: results after one year. Acta Odontol Scan, Scandinávia, v. 63, n. 3, p. 163-167. 2005.

WEYNE SC. A construção do paradigma de promoção de saúde- um desafio para as novas gerações. In: Kriger L, organizador. ABOPREV - promoção de saúde bucal. São Paulo: Editora Artes Médicas; 2003.p.1-23.

WILLIANS, S. A.; KWAN, S. Y. L.; PARSONS, S. Parental smoking practices and caries experience in pre-school children. Caries Res, Suíça, v. 34, p. 117-122, 2000. 

Anexos 



\section{ANEXO 1}

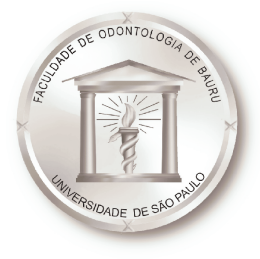

\section{Universidade de São Paulo Faculdade de Odontologia de Bauru}

AL Dr. Octávio Pinheiro Brisolla, 9-75 - Bauru-SP CEP 17012-901 - C.P. PABX (OXX14)3235-8000 - FAX (OXX14)3223-4679

Comité de Ética em (pesquisa (14)3235-8356 mferrari@fob.usp.br

Processo $n^{\circ} 010 / 2008$

Bauru, 08 de maio de 2008.

Senhora Professora,

Informamos que após o envio da documentação solicitada referente ao projeto de pesquisa encaminhado a este Comité de Ética em Pesquisa "Avaliação clínica da saúde bucal de préescolares do município de Areado-MG" de autoria de Adriana Silveira de Lima Eleutério, sob sua orientação foi novamente analisado e considerado APROVADO em reunião deste Colegiado, realizada no dia 30 de abril de 2008. Aprovou-se também a alteração do título para AVALIAÇÃO CLÍNICA DA SAÚDE BUCAL DE PRÉ-ESCOLARES DO MUNICÍPIO DE ALFENAS E AREADO-MG

Solicitamos que ao término do trabalho, seja enviado a este Comité um relatório final para novo parecer, o qual será utilizado para publicação em revista científica.

Atenciosamente,

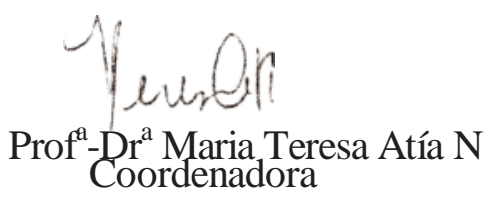

\section{Prof $^{\mathrm{a}} \mathrm{Dr}^{3}$ Saiete Moura Bonifácio da Silva}

Docente do Departamento de Odontopediatria, Ortodontia e Saúde Coletiva 


\section{ANEXO 2}

\section{TERMO DE CONSENTIMENTO LIVRE E ESCLARECIDO}

Estamos realizando uma pesquisa que tem por finalidade avaliar clinicamente a saúde bucal de pré-escolares dos Municípios de Alfenas e Areado MG.

Será verificada a condição bucal da criança, a qual consistirá no exame clínico do dente, se tem cárie ou não, no exame da placa dentária, o estado em que se encontra a gengiva e a necessidade de tratamento, sem nenhum risco ao paciente. A mãe deverá responder a um questionário com algumas perguntas, e não precisa se identificar. No final do estudo, a mãe ou responsável terá como benefício, as informações gerais sobre a saúde bucal de seu filho(a) quanto à necessidade de um tratamento preventivo ou curativo através de uma palestra, que também abordará cuidados preventivos sobre a saúde bucal da criança. Poderão ser realizadas fotografias que serão utilizadas para publicações ou aulas.

Agradecemos sua colaboração, caso concorde ou não em participar da pesquisa. Em caso de dúvidas, os pais ou responsáveis dos participantes poderão entrar em contato com a pesquisadora, e no caso de reclamações, com o Comitê de Ética em Pesquisa (CEP) da FOB/USP.

Telefone da pesquisadora em Bauru-SP -(14) 3234-9666 ou em Alfenas-MG- (35) 32919152 e telefone do CEP em Bauru-SP - (14) 3235-8356.

Pelo presente instrumento que atende às exigências legais, o Sr. (a) portador da cédula de identidade

pais ( ) ou responsáveis ( ) do(a) menor após leitura minuciosa das informações constantes neste TERMO DE CONSENTIMENTO LIVRE E ESCLARECIDO, devidamente explicada pelos profissionais em seus mínimos detalhes, ciente dos serviços e procedimentos aos quais o(a) menor acima citado será submetido, não restando quaisquer dúvidas a respeito do lido e explicado, firma seu CONSENTIMENTO LIVRE E ESCLARECIDO concordando em participar da pesquisa proposta.

Fica claro que o sujeito da pesquisa ou seu representante legal, pode a qualquer momento retirar seu CONSENTIMENTO LIVRE E ESCLARECIDO e deixar de participar desta pesquisa e ciente de que todas as informações prestadas tornaram-se confidenciais e guardadas por força de sigilo profissional (Art. $9^{\circ}$ do Código de Ética Odontológica ).Por estarem de acordo assinam o presente termo.

Bauru-SP, de de 


\section{ANEXO 3}

ÍNDICE DE PLACA VISÍVEL

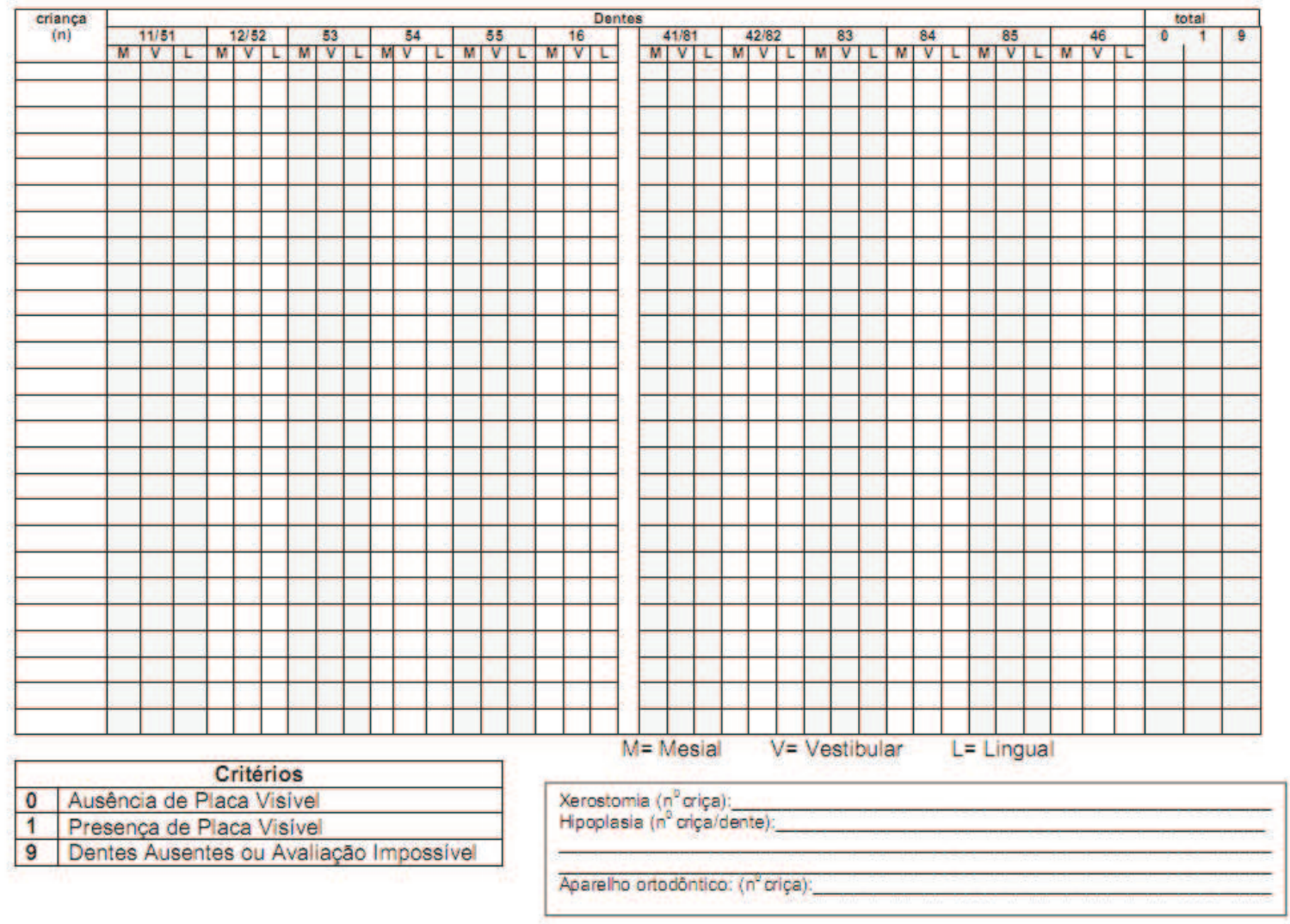

\section{ANEXO 4}

ÍNDICE DE SANGRAMENTO GENGIVAL

\begin{tabular}{|c|c|c|c|c|c|c|c|c|c|c|c|c|c|c|c|c|c|c|c|c|c|c|c|c|c|c|}
\hline \multirow{2}{*}{\multicolumn{2}{|c|}{$\begin{array}{c}\text { Criança } \\
\text { (n) }\end{array}$}} & \multicolumn{22}{|c|}{ SEGMENTOS MAXILARES } & \multirow{2}{*}{\multicolumn{3}{|c|}{ TOTAL }} \\
\hline & & \multicolumn{3}{|c|}{ SD } & \multicolumn{5}{|c|}{ SA } & \multicolumn{3}{|c|}{ SE } & \multicolumn{3}{|c|}{ IE } & \multicolumn{5}{|c|}{ IA } & \multicolumn{3}{|c|}{ ID } & & & \\
\hline & & $\begin{array}{l}3 \\
4\end{array}$ & \begin{tabular}{|l|}
4 \\
5
\end{tabular} & $\begin{array}{l}5 \\
6\end{array}$ & $\begin{array}{l}6 \\
7\end{array}$ & $\begin{array}{l}7 \\
8\end{array}$ & $\begin{array}{l}8 \\
9\end{array}$ & $\begin{array}{c}9 \\
10\end{array}$ & $\begin{array}{l}10 \\
11\end{array}$ & $\begin{array}{l}11 \\
12\end{array}$ & \begin{tabular}{|l|}
12 \\
13
\end{tabular} & $\begin{array}{l}13 \\
14\end{array}$ & $\begin{array}{l}19 \\
20\end{array}$ & $\begin{array}{l}20 \\
21\end{array}$ & $\begin{array}{l}21 \\
22\end{array}$ & $\begin{array}{l}22 \\
23\end{array}$ & \begin{tabular}{|l|}
23 \\
24
\end{tabular} & \begin{tabular}{|l|}
24 \\
25
\end{tabular} & \begin{tabular}{|l|}
25 \\
26
\end{tabular} & \begin{tabular}{|l|}
26 \\
27
\end{tabular} & $\begin{array}{l}27 \\
28\end{array}$ & \begin{tabular}{|l|}
28 \\
29
\end{tabular} & $\begin{array}{l}29 \\
30\end{array}$ & 0 & 1 & 9 \\
\hline & & & & & & & & & & & & & & & & & & & & & & & & & & \\
\hline & & & & & & & & & & & & & & & & & & & & & & & & & & \\
\hline & & & & & & & & & & & & & & & & & & & & & & & & & & \\
\hline & & & & & & & & & & & & & & & & & & & & & & & & & & \\
\hline & & & & & & & & & & & & & & & & & & & & & & & & & & \\
\hline & & & & & & & & & & & & & & & & & & & & & & & & & & \\
\hline & & & & & & & & & & & & & & & & & & & & & & & & & & \\
\hline & & & & & & & & & & & & & & & & & & & & & & & & & & \\
\hline & & & & & & & & & & & & & & & & & & & & & & & & & & \\
\hline & & & & & & & & & & & & & & & & & & & & & & & & & & \\
\hline & & & & & & & & & & & & & & & & & & & & & & & & & & \\
\hline & & & & & & & & & & & & & & & & & & & & & & & & & & \\
\hline & & & & & & & & & & & & & & & & & & & & & & & & & & \\
\hline & & & & & & & & & & & & & & & & & & & & & & & & & & \\
\hline & & & & & & & & & & & & & & & & & & & & & & & & & & \\
\hline & & & & & & & & & & & & & & & & & & & & & & & & & & \\
\hline & & & & & & & & & & & & & & & & & & & & & & & & & & \\
\hline & & & & & & & & & & & & & & & & & & & & & & & & & & \\
\hline & & & & & & & & & & & & & & & & & & & & & & & & & & \\
\hline & & & & & & & & & & & & & & & & & & & & & & & & & & \\
\hline & & & & & & & & & & & & & & & & & & & & & & & & & & \\
\hline & & & & & & & & & & & & & & & & & & & & & & & & & & \\
\hline & & & & Crit & rios & & & & & & & & dire & & & & & ante & & & & & & arc & & \\
\hline 0 & Ausé & encis & des & ang & me & $O G$ & ngiv: & & & & & $=\inf$ & esqu & erdo & & $=$ infe & erior a & anter & or & & $=$ infe & erior c & direitc & & & \\
\hline 1 & Pres & enç & des & ang & me & $O G$ & ngiv & & & & & & & & & & & & & & & & & & & \\
\hline 9 & Dent & est & usen & eso & $\mathrm{Av}$ & açà & $\operatorname{lmp}$ & ossil & & & & & & & & & & & & & & & & & & \\
\hline
\end{tabular}




\section{ANEXO 5}

ceos e CPOS

\section{Codificação Condição/estado}

\begin{tabular}{lc}
\hline Dentes & \multicolumn{1}{c}{ Dentes } \\
Decíduos & Permanentes \\
ceos & CPOS
\end{tabular}

\begin{tabular}{lrl}
\hline Coroa & Coroa & \\
A & 0 & Hígido \\
B & 1 & Cariado \\
C & 2 & Restaurado, com cárie \\
D & 3 & Restaurado, sem cárie \\
E & 4 & Ausente, devido à cárie \\
\hline & 5 & Ausente, por outros motivos \\
F & 6 & Selante de fissura \\
G & 7 & Suporte para prótese/coroa/implante \\
- & 8 & Dente não erupcionado (coroa/raiz) \\
T & T & Traumatismo (fratura) \\
- & 9 & Não registrado
\end{tabular}

Os critérios para o diagnóstico e codificação (código dos dentes decíduos entre parênteses) são:

1 (B) -2 (C) - Coroa restaurada, com cárie: quando tiver uma ou mais restaurações permanentes e uma ou mais áreas que estão com cáries.

3 (D) - Coroa restaurada, sem cárie: quando uma ou mais restaurações permanentes estão presentes e não existe cárie em ponto algum da coroa.

4 (E) - Dente ausente devido à cárie: quando para dentes permanentes ou decíduos que tenham sido extraídos devido à cárie e é registrado na

condição coronária. Para os dentes decíduos ausentes, esta classificação

somente deveria ser utilizada caso o indivíduo esteja em uma idade em que a esfoliação normal não pudesse ser uma explicação suficiente para a ausência do dente.

5 (-) - Dente permanente ausente, por qualquer outro motivo: quando dentes permanentes considerados congenitamente ausentes, ou queles extraídos por razões ortodônticas, ou devido às doenças peiodontais, traumatismo etc.

$6(F)$ - Selante de fissura: quando foi colocado um selante de fissuras na superfície oclusa; ou para os dentes nos quais a fissura oclusal foi amplamente aumentada por uma broca, com a aplicação de resina composta. Caso um dente com selamento esteja cariado, ele deveria ser codificado como 1 ou $B$.

7 (G) - Dente suporte de prótese, coroa protética, faceta e implante: quando a condição coronária indica que o dente faz parte de uma prótese parcial fixa, isto é, é um dente suporte de prótese.

8 (-) - Coroa não erupcionada: somente para dentes permanentes, quando há um espaço dentário, dente permanente não erupcionado sem um dente decíduo.

T (T) - Traumatismo (fratura): quando parte da superfície coronária está ausente como resultado de um traumatismo mas sem evidência de cáries.

9 (9) - Não registrado: quando para quaisquer dentes permanentes (adaptado para dentes decíduos) erupcionados que não possam ser examinados por qualquer razão (por exemplo, devido à presença de bandas ortodônticas, hipoplasias severa, etc.). 


\section{ANEXO 6}

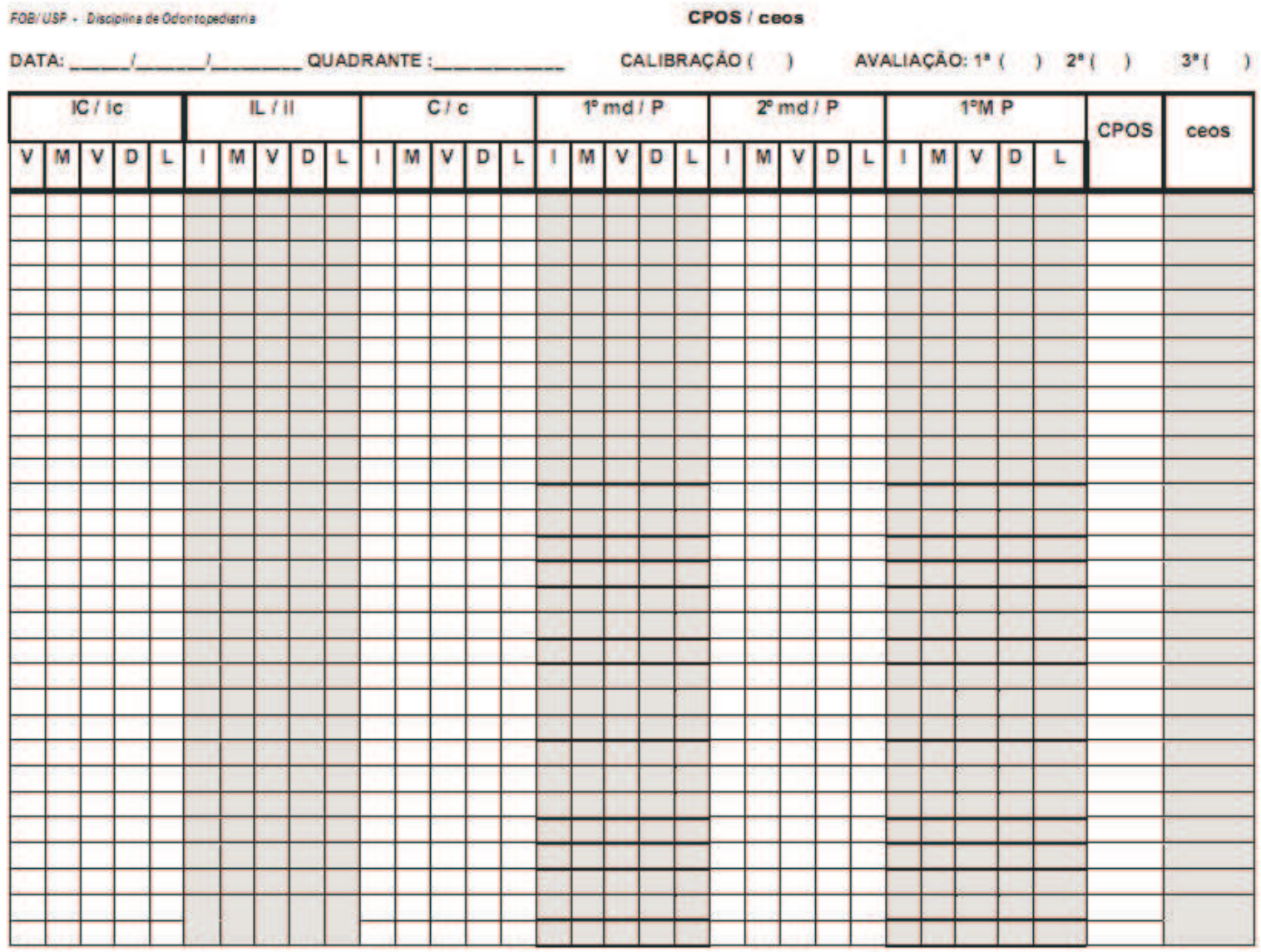




\section{ANEXO 7}

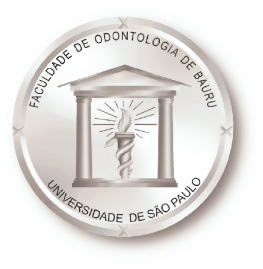

\section{Universidade de São Paulo Faculdade de Odontologia de Bauru}

AL Dr. Octávio Pinheiro Brisolla, 9-75 - Bauru-SP CEP 17012-901 - C.P. PABX (OXX14)3235-8000 - FAX (OXX14)3223-4679

Comité de Ética em (pesquisa (14)3235-8356 mferrari@fob.usp.br

\begin{tabular}{|l|l|l}
\hline & USO EXCLUSIVO DO PESQUISADOR \\
Escola: & Período: ( ) M; & ( ) $\mathrm{T} \quad$ data da entrega
\end{tabular}

\section{OBSERVAÇÃO:}

RESPONDA SINCERAMENTE A ESTE QUESTIONÁRIO, VOCÊ NÃO SERÁ IDENTIFICADO

\section{QUESTIONÁRIO AOS PAIS/RESPONSÁVEIS}

(marque um $(\mathrm{X})$ ou escreva nas linhas após as perguntas)

Data do nascimento de seu filho (a) (dia/mês/ano) : 120

Sexo: $F() ; \quad M()$

\section{FATORES SOCIAIS}

1- Idade da mãe: 15-20 anos ( ); 21-30 anos ( ); 31-40 anos ( ); ～( ) 41-50 anos

2- Idade do pai: 15-20 anos ( ); 21-30 anos ( ); 31-40 anos( ); （ ) 41-50 anos

3- MÃE: estudou até que grau? 1ำ grau ( ); $2^{\circ}$ grau ( ); $3^{\circ} \operatorname{grau}($ ) completo ( ) incompleto ( )

4- PAl: estudou até que grau? $1^{\circ} \operatorname{grau}(\quad) ; \quad 2^{\circ} \operatorname{grau}(\quad) ; \quad 30$ grau( )
( )completo
( )incompleto

5- MÃE: tem emprego? não( ) sim (

6- PAl: tem emprego? não ( ) sim (

7- Quantos filhos têm? 1( ); 2( ); 3( ); 4( );5( ) ou

8- Qual a renda da família (todos que trabalham e moram juntos)? 1 salário( ); 2 salários ( ); 3 salários ( ); 4 salários ( ); 5 salários ( ) ou salários 
9- Sua casa é: própria ( );

financiada ( );

alugada( ); emprestada ( )

10- Quantas pessoas moram na casa? E quantas fumam?

11- Com que peso seu filho nasceu?

\section{HIGIENE BUCAL}

1- Os dentes de seu filho são escovados ou limpos:

após o café da manhã;

todo dia ( ); às vezes ( )

após o almoço;

todo dia ( ); às vezes ( )

após o jantar;

todo dia ( ); às vezes ( )

antes de dormir;

todo dia ( ); às vezes ( )

2- O que é usado nessa limpeza? escova ( ); gaze ( ); fralda ( );

cotonete ( ); outros:

3- Quem limpa ou escova os dentes da criança? mãe ( ); pai ( ) criança ( ); outros:

4- Usa pasta de dente? não ( )

sim ( ), comprada em:

mercado ( )

farmácia de manipulação ( ) ou

5- A criança usa produto com flúor: bochecho ( ), gel ( ), remédio ( )?

sim, na escola ( ) sim, em casa ( ) não usa ( )

6- Conhece o fio dental? sim ( ); não ( )

7- Usa fio dental no seu filho? sim ( ); às vezes ( ) não ( )

8- Recebeu orientação de higiene bucal para seu filho? não ( ) sim ( ); quem a (o) orientou?

9- Seu filho já foi ao dentista? sim ( ); não ( ),

10- Com que freqüência? 6 meses ( ); 12 meses ( ); às vezes ( )

11- Qual foi o motivo: prevenção (limpeza - aplicação de flúor, etc.) ( ); dor ( );

tratamento de cárie ( ); $\quad$ extração de dente ( ); traumatismo ( );

outros: 


\section{HÁBITOS DA DIETA}

1- Quantas vezes ao dia seu filho come doce / guloseima: nenhuma ( ); 1( ); 2-3 ( ); $4($ ); $\quad 5$ ou mais ( )

2- Seu filho chupa chupeta: $\operatorname{sim}($ ); não ( )

3- Você coloca mel ou açúcar na chupeta ? $\operatorname{sim}($ ); não ( )

4- Seu filho mama no peito? não ( ); $\quad \operatorname{sim}($ )

e quantas vezes ao dia: $\quad 1() ; \quad 2() ; \quad 3() ; \quad$ mais de $3($ ); à noite toda $($ )

5- Seu filho usa mamadeira : não ( ); $\operatorname{sim}(\quad)$,

e quantas vezes usa mamadeira/dia : 1( ); $\quad 2() ; \quad 3() ; \quad$ mais de 3( );

6- Se seu filho mama antes de ir para a cama, ele termina de mamar dormindo?

$\operatorname{sim}() ; \quad$ não ( )

7- Seu filho mama (mamadeira) durante a noite (madrugada)?

não ( ) $\operatorname{sim}()$,

e quantas ele toma? 1( ); 2( ); 3( ); mais que 3( )

8- O que você costuma misturar no leite: açúcar ( ); $\quad$ cereal ( ) ); achocolatado ( ); outros:

9 Você dá ao seu filho outros líquidos adocicados ( por exemplo; suco, chá, refrigerante, etc.) na mamadeira ? $\operatorname{sim}($ ); não ( )

10- Com que idade seu filho começou comer comidas sólidas? ～～～ 4 meses; （ ) 4-9 meses;

( ) maior que 9 meses

11- Com que idade seu filho começou beber líquidos no copo? （）12 meses; （ ) 13-18 meses

( ) 19-24 meses; ( ) maior que 24 meses 